\title{
O CONTROLE JURISDICIONAL DO SILÊNCIO ADMINISTRATIVO
}

Dissertação apresentada à

Faculdade de Direito da

Universidade de São Paulo - USP

- para obtenção do título de

Mestre em Direito

Administrativo.

Orientador: Prof. Associado Dr. Edmir Netto de Araújo.

Universidade de São Paulo

Faculdade de Direito

São Paulo

2008 


\section{O CONTROLE JURISDICIONAL DO SILÊNCIO ADMINISTRATIVO}

Dissertação apresentada à

Faculdade de Direito da

Universidade de São Paulo - USP

- para obtenção do título de

Mestre em Direito

Administrativo.

Orientador: Prof. Associado Dr. Edmir Netto de Araújo.

Universidade de São Paulo

Faculdade de Direito

São Paulo

2008 
Pacheco, Clarissa Dertonio de Sousa

O controle jurisdicional do silêncio administrativo.

Clarissa Dertonio de Sousa Pacheco, 2008.

$160 \mathrm{p}$.

Dissertação de Mestrado - Direito Administrativo. Faculdade de Direito da Universidade de São Paulo.

Orientador: Prof. Associado Dr. Edmir Netto de Araújo.

(Direito administrativo - ato administrativo - discricionariedade e vinculação - silêncio administrativo - controle jurisdicional dos atos administrativos) 
Banca Examinadora 
Ao Roberto, sempre.

E à nossa filha Luísa, não-nascida quando da conclusão deste trabalho. 


\section{AGRADECIMENTOS}

Inicialmente, gostaria de agradecer a dedicação e o apoio do meu orientador, professor Edmir Netto de Araújo, que é tutor e amigo de todos os seus orientandos, e cuja disponibilidade e boa vontade são marcantes.

Agradeço, também, as valorosas observações dos professores Fernando Menezes de Almeida e Nestor Duarte, que compuseram a banca de qualificação desta dissertação e que muito cooperaram para seu aperfeiçoamento.

Não poderia deixar de mencionar meus colegas da pós-graduação, companheiros de jornada, que colaboraram com sugestões e críticas. Menciono, em especial, o doutorando Eduardo Hayden Carvalhaes Neto, que sempre se colocou à disposição de seus pares, não medindo esforços para atender a todos, ainda que seu próprio projeto acadêmico e suas atividades profissionais lhe tomassem considerável tempo.

Manifesto, ainda, minha enorme gratidão pelo auxílio inestimável do amigo Marcos Benacchio, que leu todo o projeto e apresentou suas observações, sempre muito inteligentes e oportunas.

Por fim, agradeço à minha família, cujo suporte, nesta e em todas as atividades nas quais me envolvo, tem caráter fundamental. Aos meus pais, Flávia e Antonio Carlos, meus irmãos, Gabriela e Diogo, e ao meu marido, Roberto, meu muito obrigada. 


\section{ÍNDICE}

\section{Conteúdo}

NOTAS INTRODUTÓRIAS .............................................................................................. 9

1 O CONTROLE EXTERNO DA ADMINISTRAÇÃO PELO PODER JUDICIÁRIO ................................. 14

1.1 Origem histórica - a teoria da separação dos Poderes.............................................................. 14

1.2 A separação dos Poderes como fundamento do Estado Democrático de Direito.................. 18

1.3 Os Poderes do Estado e o sistema de freios e contrapesos...................................................... 21

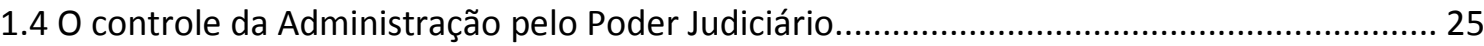

1.5 A evolução histórica do controle jurisdicional da Administração............................................ 30

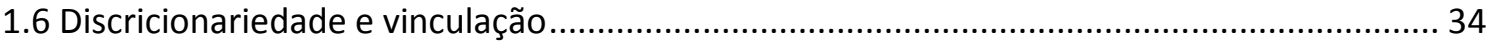

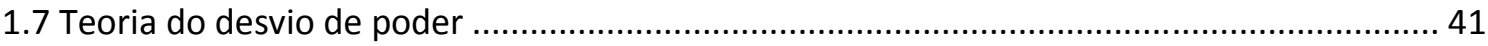

1.7.1 O desvio de poder alheio a qualquer interesse público ................................................ 44

1.7.2 O desvio de poder visando a interesse público distinto do previsto em lei .....................46

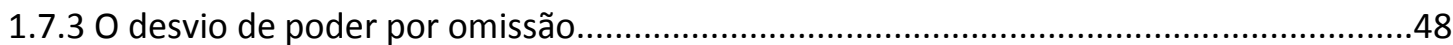

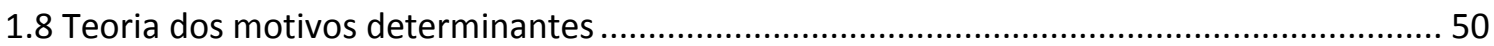

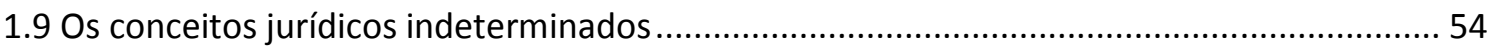

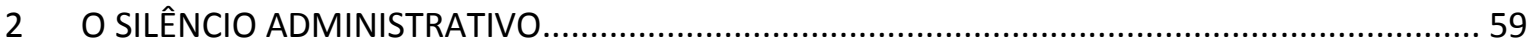

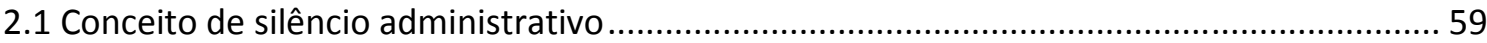

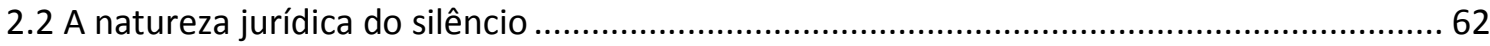

2.3 A teoria do silêncio administrativo - as conseqüências do silêncio da Administração .......... 70

$2.4 \mathrm{O}$ silêncio administrativo no Direito estrangeiro ................................................................. 74

2.4.1 O silêncio administrativo no Direito italiano ................................................................... 74

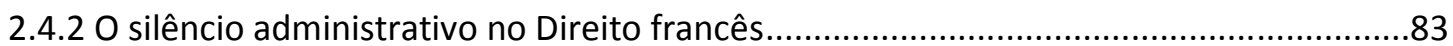

2.4.3 O silêncio administrativo no Direito português .............................................................. 87

2.4.4 O silêncio administrativo no Direito espanhol .................................................................92

2.4.5 O silêncio administrativo no Direito argentino ..............................................................99

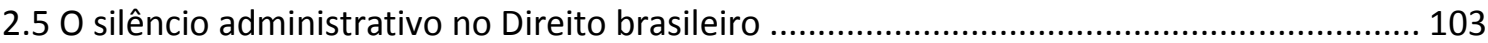

2.5.1 O silêncio administrativo na legislação brasileira .............................................................. 104

2.5.2 O silêncio administrativo na jurisprudência brasileira................................................... 111

3 O CONTROLE DO SILÊNCIO ADMINISTRATIVO PELO PODER JUDICIÁRIO ............................... 113

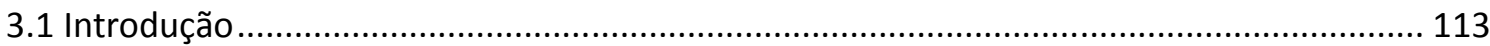

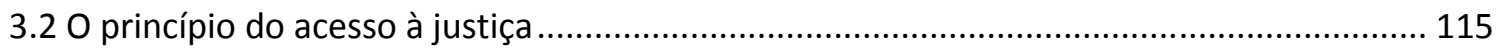


3.3 A necessidade da caracterização do silêncio administrativo como interesse de agir 118

3.4 Os limites ao controle do silêncio administrativo pelo Poder Judiciário 123

3.5 O estabelecimento de astreintes contra o Poder Público 127

3.6 Responsabilização do Estado pelo silêncio administrativo... 133

3.7 A responsabilização do servidor pelo silêncio administrativo 138

3.8 A possibilidade de se praticar ato expresso após a caracterização de um "ato tácito" 142

4 CONCLUSÕES. 148

RESUMO 151

RESUMÉ 152

BIBLIOGRAFIA 153 


\section{NOTAS INTRODUTÓRIAS}

O tema proposto a desenvolver no presente trabalho é o Controle Jurisdicional do Silêncio Administrativo.

O controle externo da Administração é tema que tem suscitado discussões bastante profícuas, seja na doutrina, seja na jurisprudência. Aliás, boa parte dos conceitos ligados ao controle jurisdicional da Administração - como as teorias do desvio de poder e dos motivos determinantes, que serão tratadas na dissertação - tem berço pretoriano. Não se trata de assunto recente ou inédito, mas, com a incessante evolução da sociedade, sua reflexão parece sempre atual. Sendo assim, a primeira parte da dissertação dedica-se ao Controle Externo da Administração pelo Poder Judiciário: suas origens, características e limites.

Ao contrário do que acontece em outros países, nos quais o silêncio administrativo vem merecendo atenção da doutrina, da jurisprudência e até mesmo dos legisladores, no Brasil, o tema não tem sido objeto de estudo muito freqüente entre os jurisdoutrinadores. A despeito disso - ou talvez exatamente por isso - o exame do silêncio da Administração pareceu digno de atenção, especialmente porque se liga a diversos conceitos de Direito Administrativo e também de Direito Privado. Sendo assim, a segunda parte é voltada ao estudo do Silêncio Administrativo: seu conceito, natureza jurídica, seu tratamento nos sistemas jurídicos alienígenas.

Na terceira e última parte do trabalho, apresenta-se a intersecção entre os assuntos anteriormente versados, para a discussão proposta no título da dissertação: o Controle Jurisdicional do Silêncio Administrativo.

O afunilamento para este tema decorreu da observância de que, no estudo dos limites ao controle do ato administrativo pelo Poder Judiciário, ganha especial relevo a questão da inação administrativa. 
De fato, o controle da omissão estatal exige cuidado especial. Nela, é muito mais tênue a linha que separa a vinculação da discricionariedade, ganhando maior amplitude a discussão acerca da autonomia e interdependência entre os Poderes.

Não se pode admitir que o Poder Judiciário, a pretexto de defender direito de um particular que se lhe dirigiu, se substitua, indevidamente, à Administração, fazendo escolhas que somente a ela seriam cabíveis.

Como anota Edmir Netto de Araújo, "o que não pode é o Judiciário substituir-se à Administração, tomando seu lugar na valoração interna do ato e na adoção das providências de sua competência para o objetivo colimado com o ato" ${ }^{\text {.1 }}$

De outro lado, é evidente que a omissão do Estado não pode, simplesmente, ser afastada do controle jurisdicional. A se entender assim, o Estado deteria, em suas mãos, maneira de escapar à sindicância judicial, subtraindo, dessa forma, competência constitucionalmente outorgada àquele Poder.

Até porque, a teoria da separação de Poderes tem dois vieses a serem considerados: de um lado, implica a não-interferência de um Poder em outro, isto é, a vedação da assunção por um Poder das competências inerentes a outro. De outra banda, importa a contenção recíproca entre os Poderes, mediante o chamado sistema de freios e contrapesos.

Ademais, como se expõe logo no primeiro capítulo do trabalho, a teoria da separação de Poderes surgiu, essencialmente, para proteger os direitos individuais contra os desmandos do Estado - revelando-se, após, instrumento de eficiência da atividade estatal.

Sendo assim, é inconcebível que a Administração, ferindo direitos individuais ou coletivos (ou deixando de atendê-los), proteja-se sob o manto da independência dos Poderes para descumprir a lei.

\footnotetext{
${ }^{1}$ ARAÚJO, Edmir Netto de. Curso de Direito Administrativo. $1^{\text {a }}$ ed. São Paulo: Saraiva, 2005, p. 453.
} 
Acresça-se que, por direitos fundamentais, entende-se, hoje, um amplo espectro de interesses. Incluem-se entre os direitos fundamentais cujo exercício poderia ser obstado pela inércia administrativa - ou, mais especificamente, pelo silêncio da Administração - o livre exercício dos cultos religiosos ${ }^{2}$ (que poderia ser impedido, por exemplo, com a deliberada mora da Administração em conceder um alvará de funcionamento ao templo), direito à informação ${ }^{3}$ (deixando a Administração de responder a consulta do administrado sobre assunto de seu interesse), o direito à obtenção de certidão ${ }^{4}$ (pelo retardamento ou omissão do fornecimento), a ampla defesa ${ }^{5}$ (cujo exercício pressupõe o conhecimento dos motivos que levaram a Administração a indeferir seu pedido, por exemplo), a razoável duração do processo $^{6}$ (pois a inatividade da Administração prolonga, indevidamente, o processo administrativo), entre outros.

Como escreve, com muita propriedade, José Afonso da Silva, "a lei não deve ficar numa esfera puramente normativa, não pode ser apenas lei de arbitragem, pois precisa influir na realidade social". ${ }^{7}$ Não se pode permitir que a lei se transforme em letra morta menos ainda quando se cuida da Constituição Federal, ápice do nosso sistema jurídico. Daí porque o controle jurisdicional deve buscar, também, a efetividade das normas constitucionais.

Não se pode olvidar, porém, que o Judiciário é um Poder inerte, que deve ser provocado pelo interessado. E não se pode pronunciar sobre o mérito do pedido perante ele apresentado senão quando preenchidos determinados requisitos - as chamadas condições da ação.

No âmbito de estudo proposto, uma das condições da ação, em especial, ganha relevância - cuida-se do interesse jurídico. De fato, como comprovar a resistência da Administração e o interesse jurídico do administrado, no caso de silêncio?

\footnotetext{
${ }^{2}$ Art. $5^{\circ}, \mathrm{VI}, \mathrm{CF}$.

${ }^{3}$ Art. $5^{\circ}$, XIV e XXXIII, CF.

${ }^{4}$ Art. 5", XXXIV, "b", CF.

${ }^{5}$ Art. $5^{\circ}, \mathrm{LV}, \mathrm{CF}$.

${ }^{6}$ Art. $5^{\circ}$, LXXVIII, CF.

${ }^{7}$ SILVA, José Afonso da. Curso de Direito Constitucional Positivo, 23 a ed. São Paulo: Malheiros, 2004. p.121.
} 
Deve-se acrescentar, ainda, que esta dissertação restringe-se à analise das questões suscitadas pelo silêncio administrativo. Excluiu-se de seu âmbito, pois, o estudo das demais omissões estatais - o que resultaria em um espectro muito amplo, no qual se incluem o controle das políticas públicas e os instrumentos processuais a ele referentes (hipótese em que a dissertação teria uma tônica muito mais processual que administrativa), além da responsabilidade do Estado por atos omissivos. No limite, o estudo da omissão estatal envolve também as omissões legislativas e os respectivos instrumentos de controle - Mandado de Injunção e Ação de Inconstitucionalidade por Omissão - que são objetos de estudo do Direito Constitucional.

Por tais razões, o presente trabalho enfocará a inatividade formal da Administração - o silêncio - e não cuidará das demais omissões, referidas como inatividade material do Estado.

Conforme explica o Juiz do Contencioso Administrativo e Tributário de Buenos Aires, Fernando E. Juan Lima,

Usualmente se distingue entre a inatividade formal e a inatividade material da Administração. Tradicionalmente se tem referido o conceito de silêncio administrativo aos casos de inatividade formal, concorreram para isto razões de ordem histórica, que se introduziram no nosso direito positivo e na doutrina nacional pela influência do direito administrativo francês ${ }^{8}$.

Fala-se em silêncio da Administração quando a omissão se refere a um pronunciamento. Deduzindo o administrado pedido ou consulta, queda-se inerte a Administração.

Na doutrina estrangeira costuma-se reservar a expressão silêncio administrativo apenas para os casos em que a inação administrativa recebe uma conotação da lei, implicando o acolhimento ou a rejeição da pretensão do postulante.

Mais uma vez na doutrina do argentino Fernando Juan Lima,

\footnotetext{
${ }^{8}$ JUAN LIMA, Fernando E. el silencio Administrativo: Problemas Actuales. Revista Eletrônica de Direito do Estado - ReDE n⿳07/2006, Instituto de Direito Público da Bahia, Salvador, p. 2. Disponível na Internet: http://www.direitodoestado.com.br . Acesso em 15 de outubro de 2007. (tradução livre)
} 
GONZALES NAVARRO sustenta que o silêncio pode ser definido como uma ficção que a lei estabelece em benefício do interessado e em virtude da qual se considera deferida (silêncio positivo) ou indeferida (silêncio negativo) a solicitação daquele quando a Administração descumpre o dever que tem de resolver e concorrem os demais requisitos exigidos por lei ${ }^{9}$.

$\mathrm{Na}$ doutrina pátria, porém, o termo é, usualmente, empregado para designar a ausência de um pronunciamento, de uma decisão da Administração perante o pleito de um interessado, haja ou não consequiência legal prevista. Celso Antonio Bandeira de Mello, por exemplo, anota que "se a Administração não se pronuncia quando deve fazê-lo, seja porque foi provocada por administrado que postula interesse próprio, seja porque um órgão tem de pronunciar-se para fins de controle de ato de outro órgão, está-se perante o silêncio administrativo" $" 10$.

O estudo ainda versa sobre o controle jurisdicional do silêncio administrativo. A questão se torna mais complexa nas hipóteses em que não há uma conseqüência legal prevista. Neste caso, como deverá o interessado comprovar seu interesse jurídico? Superada esta questão, quais os limites do provimento jurisdicional? Poderá o juiz suprir a omissão estatal ou deverá limitar-se a determinar à Administração que se manifeste?

Em suma, os objetivos gerais do trabalho são estudar o controle externo da Administração e o silêncio administrativo, permitindo-se, então, como objetivo específico, analisar o controle do silêncio administrativo pelo Poder Judiciário.

\footnotetext{
${ }^{9}$ JUAN LIMA, Fernando E. el silencio Administrativo: Problemas Actuales. Revista Eletrônica de Direito do Estado - ReDE n⿳07/2006, Instituto de Direito Público da Bahia, Salvador, p. 3. Disponível na Internet: http://www.direitodoestado.com.br . Acesso em 15 de outubro de 2007. (tradução livre).

${ }^{10}$ BANDEIRA DE MELlO, Celso Antônio. Curso de Direito Administrativo. $22^{\mathrm{a}}$ ed. São Paulo: Malheiros, 2007, p. 395.
} 


\section{O CONTROLE EXTERNO DA ADMINISTRAÇÃo PELO PODER JUDICIÁRIO}

\subsection{Origem histórica - a teoria da separação dos Poderes}

A questão acerca dos limites ao controle externo da Administração pelo Poder Judiciário tem raízes na teoria da separação de Poderes.

De início, cumpre fazer uma observação de ordem terminológica. Sendo o Poder estatal uno e indivisível ${ }^{11}$, afigura-se inapropriado, em princípio, referir-se a uma separação de Poderes. O Poder estatal é muito amplo, o que torna imperiosa a necessidade de vários órgãos a exercê-lo - sem que se possa falar em cisão desse Poder. Há quem sustente ser mais adequado dizer distribuição de funções ${ }^{12}$. Todavia, cuidando-se de expressão absolutamente consagrada pela doutrina, será utilizada neste trabalho, feita a ressalva precedente.

Costuma-se creditar a teoria da separação de Poderes a Montesquieu. A doutrina referente ao estudo dos Poderes ou funções do Estado e à sua distribuição tem, contudo, antecedentes mais remotos.

Em Aristóteles já se encontram estudos acerca das funções do Estado e da melhor maneira de se constituir um governo a fim de atender ao bem comum. Após comparar regimes viciados - a Oligarquia, governo dos ricos para os ricos, e a Democracia, governo dos pobres para os pobres, o filósofo propõe um regime misto. Como explica Marilena Chauí,

\footnotetext{
${ }^{11}$ SILVA, José Afonso da. Curso de Direito Constitucional Positivo. 23 a ed. São Paulo: Malheiros, 2004, p. 107: "Disso decorrem as três características fundamentais do poder político: unidade, indivisibilidade e indelegabilidade, de onde parecer impróprio falar-se em divisão e delegação de poderes (...)".

${ }^{12}$ DALLARI, Dalmo de Abreu. Elementos de Teoria Geral do Estado. 19a ed. São Paulo: Saraiva, 1995. p. 181.

TEMER, Michel. Elementos de Direito Constitucional. $18^{\mathrm{a}}$ ed. São Paulo: Malheiros, 2002. p. 118: "equivocam-se os que utilizam a expressão 'tripartição dos poderes'. É que o poder é uma unidade. (...) é atributo do Estado".
} 
O regime misto é uma mistura de oligarquia e democracia na qual se procura realizar o justo meio entre os dois grupos opostos que dividem a cidade, ou seja, tomando-se a pólis realmente existente, com suas condições materiais e sociais, e com suas divisões, trata-se de encontrar uma ordenação capaz de realizar o bem comum da Cidade. (...) Por isso o regime misto é aquele em que o governo cabe às leis. Ou é "o governo da lei”, isto é, não é governo da ciência, nem governo do Bem, nem o dos melhores, nem o da virtude, mas a moderação entre as partes antagônicas da Cidade por meio da lei. ${ }^{13}$

Embora Aristóteles tenha identificado diferentes funções do Estado, não sugeriu sua distribuição por diferentes órgãos estatais.

John Locke também estudou as diferentes funções do Estado, propondo, em seus Dois Tratados dobre o Governo Civil, a divisão entre Poder Legislativo, Executivo e Federativo. O Poder Legislativo teria superioridade sobre os demais, sendo um Poder supremo - o que talvez se explique pela visão, essencialmente positiva, que Locke tinha do estado de natureza, concebendo, pois, o contrato social como um verdadeiro pacto de consentimento. O Poder Executivo seria confiado ao príncipe, enquanto que ao Poder Federativo incumbiria tratar das relações exteriores - como guerra, paz, alianças e tratados. Cláudio de Cicco escreveu que, após a Revolução Inglesa, notadamente com o Bill of Rights de 1688, as idéias de Locke passaram a ser aceitas na Inglaterra. Anota o autor:

(...) não se conceberia mais o poder do rei como executivo e legislativo ao mesmo tempo. A divisão de poderes nascia: o rei era detentor da chefia do Estado, o Parlamento governava a Inglaterra, sendo suas atribuições as legislativas. O Poder Executivo era exercido pelo primeiro-ministro, como voto de confiança do Parlamento. Esse regime, o Parlamentarismo, até hoje vigora naquele país. ${ }^{14}$

Mas foi Montesquieu quem, em sua obra De L'Esprit des Lois, de 1748, sistematizou a divisão orgânica das funções - comumente referida como tripartição dos Poderes - que fundamenta as modernas democracias.

O filósofo escreveu:

\footnotetext{
${ }^{13}$ CHAUI, Marilena. Introdução à História da Filosofia. Vol. I. 2 ${ }^{\mathrm{a}}$ ed. São Paulo: Companhia das Letras, 2002, p. 476.

${ }^{14}$ DE CICCO, Cláudio. História do Pensamento Jurídico e da Filosofia do Direito. $3^{\text {a }}$ ed. São Paulo: Saraiva, 2006, p. 127.
} 
Há, em cada Estado, três espécies de poderes: o poder legislativo, o poder executivo das coisas que dependem do direito das gentes, e o poder executivo das que dependem do direito civil.

Pelo primeiro, o príncipe ou magistrado faz leis por certo tempo ou para sempre e corrige ou ab-roga as que estão feitas. Pelo segundo, faz a paz ou a guerra, envia ou recebe embaixadas, estabelece a segurança, previne as invasões. Pelo terceiro, pune os crimes ou julga as querelas dos indivíduos. Chamaremos este último de poder de julgar e o outro, simplesmente o poder executivo do Estado.

$$
\text { (...) }
$$

Quando na mesma pessoa ou no mesmo corpo de magistratura o poder legislativo está reunido ao poder executivo, não existe liberdade, pois pode-se temer que o mesmo monarca ou o mesmo senado apenas estabeleçam leis tirânicas para executá-las tiranicamente.

Não haverá também liberdade se o poder de julgar não estiver separado do poder legislativo e do executivo. Se estivesse ligado ao poder legislativo, o poder sobre a vida e a liberdade dos cidadãos seria arbitrário, pois o juiz seria legislador. Se estivesse ligado ao poder executivo, o juiz poderia ter a força de um opressor.

Tudo estaria perdido se o mesmo homem ou o mesmo corpo dos principais, ou dos nobres, exercesse esses três poderes: o de fazer leis, o de executar as resoluções públicas e o de julgar os crimes ou as divergências dos indivíduos ${ }^{15}$.

A inovação da obra de Montesquieu, portanto, não reside em identificar as diferentes funções (ou Poderes) do Estado, mas em distribuí-las a órgãos diferentes, de modo a que, na lição de Michel Temer, "cada órgão desempenhasse função distinta e, ao mesmo tempo, que a atividade de cada qual caracterizasse forma de contenção da atividade de outro órgão do poder". 16

Como observa Celso Antonio Bandeira de Mello,

o pensamento do barão de Montesquieu, acima de tudo pragmático, fundava-se na observação de um fato, por ele afirmado como uma constante indesmentida e cuja procedência realmente não admite contestação, isto é: todo aquele que tem poder, tende a abusar dele ${ }^{17}$.

Deve-se observar que, embora se utilize, por vezes, a expressão eqüipotência em relação à teoria da tripartição dos Poderes proposta por Montesquieu, o fato é que, em sua

\footnotetext{
${ }^{15}$ MONTESQUIEU. Do Espírito das Leis. Vol. I. Coleção “Os Pensadores”. Traduções publicadas sob licença da Editora Bertrand Brasil, RJ. São Paulo: Nova Cultural, pp. 201/202.

16 TEMER, Michel. Elementos de Direito Constitucional. $18^{a}$ ed. São Paulo: Malheiros, 2002, p. 119.

${ }^{17}$ BANDEIRA DE MELLO, Celso Antônio. Discricionariedade e Controle Jurisdicional. $2^{\mathrm{a}}$ ed. São Paulo: Malheiros, 2003, pp. 11/12.
} 
obra, os Poderes não são igualmente relevantes. O autor chega mesmo a escrever que "dos três poderes dos quais falamos, o de julgar é, de algum modo, nulo". ${ }^{18}$ A doutrina de Montesquieu fundamenta a teoria dos freios e contrapesos não porque proponha valoração eqüitativa para cada uma das três funções governamentais, mas porque concebe cada um dos Poderes como moderador dos demais.

${ }^{18}$ MONTESQUIEU. Do Espírito das Leis. Vol. I. Coleção “Os Pensadores”. Traduções publicadas sob licença da Editora Bertrand Brasil, RJ. São Paulo: Nova Cultural, p. 203. 


\subsection{A separação dos Poderes como fundamento do Estado Democrático de Direito}

As idéias do Barão de Montesquieu tiveram influência marcante sobre a Revolução Francesa de 1789, que foi um marco na história ocidental contemporânea. Os desmandos da Monarquia Absolutista, contra a qual se insurgiram os revoltosos, evidenciaram os desvios existentes com a concentração do Poder estatal em um só governante.

A tal ponto a separação de Poderes foi relacionada a um Estado Democrático de Direito que o princípio consta da Declaração dos Direitos do Homem e do Cidadão, de 1789, no artigo 16: “Toute Société dans laquelle la garantie des Droits n'est pas assurée, ni la séparation des Pouvoirs déterminée, n'a point de Constitution". ${ }^{9}$

Desde então, praticamente todo o mundo ocidental adotou o sistema de divisão orgânica tripartite das funções estatais - embora cada Estado lhe dê nuanças próprias. É o que anota Marçal Justen Filho:

Tome-se em conta que não existe uma única teoria da separação de Poderes, compartilhada igualmente por todos os países. A teoria da separação de Poderes é adotada em quase todos os países, mas com configurações próprias e inconfundíveis. Ou seja, não há um modelo único de separação de Poderes, mas cada Estado produz uma teoria própria, que reflete sua experiência histórica. Por exemplo, a separação de Poderes nos EUA é muito diferente daquela existente na França. E nenhuma delas é similar à brasileira. Mas todos os Estados compartilham uma experiência comum: a impossibilidade de separação absoluta de funções. ${ }^{20}$

A tripartição de Poderes, consagrada no artigo $2^{\circ}$ da Constituição da República Federativa do Brasil, estabelece: "São Poderes da União, independentes e harmônicos entre si, o Legislativo, o Executivo e o Judiciário".

\footnotetext{
19 "Uma sociedade na qual a garantia dos Direitos não é assegurada, nem a separação dos Poderes determinada, não tem Constituição" (tradução livre).

${ }^{20}$ JUSTEN FILHO, Marçal. Curso de Direito Administrativo. $1^{\text {a }}$ ed. São Paulo: Saraiva, 2005, p. 24.
} 
A Constituição Portuguesa de 1997 faz constar este princípio ao lado de outros, também considerados pilares do Estado Democrático de Direito, em seu artigo $2^{\circ}$ :

A República Portuguesa é um Estado de direito democrático, baseado na soberania popular, no pluralismo de expressão e organização política democráticas, no respeito e na garantia de efectivação dos direitos e liberdades fundamentais e na separação e interdependência de poderes, visando a realização da democracia económica, social e cultural e o aprofundamento da democracia participativa.

Em suma, pode-se afirmar que a teoria clássica da repartição de Poderes assenta-se sobre três postulados essenciais: a) a diferenciação de estruturas organizacionais estatais, autônomas umas em relação às outras, às quais se convencionou chamar "Poderes"; b) a identificação das diversas funções estatais, a partir de sua substância (separação “funcional" de Poderes); c) a atribuição, a cada Poder, de um tipo de função ${ }^{21}$.

Mas a distribuição das funções estatais por diferentes Poderes é um dos elementos que caracterizam o Estado Democrático de Direito. Na lição de Celso Antônio Bandeira de Mello, "a grande novidade do Estado de Direito certamente terá sido subjugar totalmente a ação do Estado a um quadro normativo, o qual se faz, assim, impositivo para todos Estado e indivíduos"22.

Até porque, observa Américo Bedê Freire Júnior,

(...) a separação de poderes não é um fim em si mesmo, mas um instrumento concebido com o intuito de viabilizar uma efetividade às conquistas obtidas com o movimento constitucionalista.

A principal característica do movimento constitucionalista foi, sem dúvida alguma, a afirmação dos direitos fundamentais como epicentro do sistema jurídico.

Nesse diapasão, deve ser frisado que não apenas os direitos da primeira geração devem ser protegidos pela separação de poderes, mas todas as gerações dos direitos fundamentais, já que uma das características dos direitos individuais é sua indivisibilidade. Todas as dimensões dos direitos fundamentais, portanto, podem (devem) ser protegidas pelo princípio em comento ${ }^{23}$.

Conforme explica José Afonso da Silva:

${ }^{21}$ JUSTEN FILHO, Marçal. Curso de Direito Administrativo. $1^{\mathrm{a}}$ ed. São Paulo: Saraiva, 2005, pp. $24 / 25$.

${ }^{22}$ BANDEIRA DE MELLO, Celso Antônio. Discricionariedade e Controle Jurisdicional. $2^{\mathrm{a}}$ ed. São Paulo: Malheiros, 2003, p. 11.

${ }^{23}$ FREIRE JÚNIOR, Américo Bedê. O Controle Judicial de Políticas Públicas. São Paulo: RT, 2005, p. 38. 
Na origem, como é sabido, o Estado de Direito era um conceito tipicamente liberal; daí falar-se em Estado Liberal de Direito, cujas características básicas foram: (a) submissão ao império da lei, que era a nota primária de seu conceito, sendo a lei considerada como ato emanado formalmente do Poder Legislativo, composto de representantes do povo, mas do povo-cidadão; $(b)$ divisão de poderes, que separe de forma independente e harmônica os poderes Legislativo, Executivo e Judiciário, como técnica que assegure a produção das leis ao primeiro e a independência e imparcialidade do últimos em face dos demais e das pressões dos poderosos e particulares; (c) enunciado e garantia dos deveres individuais. Essas exigências continuam a ser postulados básicos do Estado de Direito, que configura uma grande conquista da civilização ocidental $^{24}$.

Maria Sylvia Zanella Di Pietro também aponta aqueles que, na concepção clássica do Estado de Direito, são considerados seus pontos fundamentais:

1. o reconhecimento da liberdade dos cidadãos, dotados de direitos fundamentais, universais, inalienáveis;

2. o princípio da legalidade, segundo o qual ninguém pode ser afetado em sua liberdade senão em virtude de lei e que traz, como conseqüência, a vinculação da Administração Pública à lei;

3. o princípio da justicialidade, que exige a existência de um órgão independente para decidir os litígios;

4. o princípio da igualdade de todos perante o direito, vedado qualquer tipo de discriminação;

5. a concepção substancial do direito que, fazendo-o decorrer da natureza do homem, imprime-lhe caráter de justiça ${ }^{25}$.

Para a caracterização de um verdadeiro Estado de Direito, pois, à repartição das funções devem-se somar o princípio da legalidade, preservação dos direitos e garantias individuais e o controle externo da Administração por um órgão independente.

\footnotetext{
${ }^{24}$ SILVA, José Afonso da. Curso de Direito Constitucional Positivo, 23 ${ }^{\mathrm{a}}$ ed. São Paulo: Malheiros, 2004, p. 113.

${ }^{25}$ DI PIETRO, Maria Sylvia Zanella. Discricionariedade Administrativa na Constituição de 1988. $2^{\mathrm{a}}$ ed. Atlas, SP:2001, pp.22/23.
} 


\subsection{Os Poderes do Estado e o sistema de freios e contrapesos}

Para que o sistema de repartição de funções estatais atinja seu objetivo - qual seja, de mútua contenção entre os órgãos encarregados do exercício das funções como garantia do Estado de Direito - , é necessário, ainda, que os Poderes sejam independentes e harmônicos entre si - falando-se, mais modernamente, em interdependência dos Poderes (vocábulo, aliás, expressamente mencionado pela Constituição Portuguesa no artigo $2^{\circ}$, transcrito no item anterior).

De início, impõe-se distinguir, em linhas gerais, os Poderes ou funções estatais.

Cada um dos Poderes se caracteriza por uma função típica ou predominante - 0 que não significa que não possa exercer outras, as atípicas.

A função típica do Poder Legislativo é, por excelência, legislar, isto é, editar normas gerais e abstratas. O artigo 59 da Constituição Federal do Brasil relaciona todas as espécies normativas que nossa ordem jurídica admite. Sua produção é tarefa do Poder Legislativo, à exceção das Medidas Provisórias e Leis Delegadas, que o Presidente da República edita, independentemente de prévia aprovação do Poder Legislativo. As exceções se justificam: no primeiro caso, das Medidas Provisórias, há uma situação de relevância e urgência ${ }^{26}$ que demanda solução rápida, impedindo que se aguarde todo o processo legislativo. As Leis Delegadas excepcionam o princípio da indelegabilidade de atribuições; para editá-las, deve o Presidente da República submeter solicitação ao Poder Legislativo, delimitando a matéria a ser objeto de lei delegada ${ }^{27}$. De qualquer forma, a titularidade da competência legislativa continua a pertencer ao Poder Legislativo que, aliás, pode legislar sobre a mesma matéria versada na solicitação presidencial.

\footnotetext{
${ }^{26}$ Art. 62 da CF.

${ }^{27}$ Art. 68 da CF.
} 
Também constitui função típica do Poder Legislativo a fiscalizatória ${ }^{\mathbf{2 8}}$. Ao Poder Legislativo incumbe a fiscalização contábil, financeira, orçamentária e patrimonial do Poder Executivo. Esta fiscalização dá-se, especialmente, com o auxílio do Tribunal de Contas $^{29}$.

Atipicamente, o Poder Legislativo pratica atos de natureza executiva - como, por exemplo, quando concede férias a um servidor. Também pode, excepcionalmente, julgar o que ocorre, verbi gratia, no caso dos crimes de responsabilidade do Presidente da República $^{30}$.

A função típica do Poder Executivo é administrar, dando cumprimento à lei editada pelo Poder Legislativo. O Poder Executivo ainda exerce atos de chefia de Estado e de governo ${ }^{31}$.

De forma não-predominante, pode o Poder Executivo praticar atos de índole legislativa - como faz quando edita as mencionadas Medidas Provisórias ou Leis Delegadas - e jurisdicional - o que acontece quando decide sobre recursos e defesas administrativos e procedimentos disciplinares, por exemplo.

Ao Poder Judiciário compete julgar ${ }^{32}$, aplicando a lei ao caso concreto, pacificando os conflitos que se lhe apresentam com definitividade, isto é, com autoridade de coisa julgada.

Pratica funções atípicas como a legislativa, ao editar os regimentos internos de seus Tribunais $^{33}$, e executiva, quando concede licença a magistrado ou funcionário, realiza licitações etc.

Como se percebe, a distinção das funções dos Poderes do Estado não é absoluta nem tampouco estanque; os Poderes se caracterizam por suas funções típicas ou precípuas.

\footnotetext{
${ }^{28}$ Art. 70 da CF.

${ }^{29}$ Art. 71 da CF.

${ }^{30}$ Art. 86 da CF.

${ }^{31}$ Art. 84 da CF.

${ }^{32}$ Art. $5^{\circ}, \mathrm{XXXV}$, da CF.

${ }^{33}$ Art. 96, "a", da CF.
} 
Na lição de José Afonso da Silva:

A divisão de poderes fundamenta-se, pois, em dois elementos: $(a)$ especialização funcional, significando que cada órgão é especializado no exercício de uma função; assim, às assembléias (Congresso, Câmara, Parlamento) se atribui a função Legislativa; ao Executivo, a função executiva; ao Judiciário, a função jurisdicional; $(b)$ independência orgânica, significando que, além da especialização funcional, é necessário que cada órgão seja efetivamente independente dos outros, o que postula ausência de meios de subordinação. Trata-se, pois, como se vê, de uma forma de organização jurídica das manifestações do Poder ${ }^{34}$.

Exercendo cada um dos Poderes suas funções típicas, estabelece-se um equilíbrio entre eles. Fala-se em sistema de freios e contrapesos (a teoria dos checks and balances).

As funções dos Poderes Executivo e Judiciário são infralegais, estando, pois, limitadas pelas normas que o Poder Legislativo edita. O Poder Executivo, atuando concretamente a lei, analisa os fatos que se lhe apresentam e verifica se há a necessária subsunção à lei. Mas atua, sempre, dentro da moldura legal, ainda quando exista uma margem de discricionariedade (tema que será abordado mais adiante).

Tanto o Poder Legislativo quando o Poder Executivo são limitados pelo Poder Judiciário, se exorbitarem sua esfera de competência ou, de qualquer forma, agirem contrariamente à ordem jurídica pátria. Evidentemente, o Poder Judiciário não pode limitar a atuação dos demais Poderes se não constatada nenhuma irregularidade; do contrário, não haveria equilíbrio entre eles, mas prevalência do Poder Judiciário.

Sintetizando o quanto exposto, escreve Dalmo de Abreu Dallari:

O sistema de separação dos poderes, consagrado nas Constituições de quase todo o mundo, foi associado à idéia de Estado Democrático e deu origem a uma engenhosa construção doutrinária, conhecida como sistema de freios e contrapesos. Segundo essa teoria os atos que o Estado pratica podem ser de duas espécies: ou são atos gerais ou são especiais. Os atos gerais, que só podem ser praticados pelo poder

\footnotetext{
${ }^{34}$ SILVA, José Afonso da. Curso de Direito Constitucional Positivo, 23 ${ }^{\mathrm{a}}$ ed. São Paulo: Malheiros, 2004, p.
} 109. 
legislativo, constituem-se a emissão de regras gerais e abstratas, não se sabendo, no momento de serem emitidas, a quem elas irão atingir. Dessa forma, o poder legislativo, que só pratica atos gerais, não atua concretamente na vida social, não tendo meios para cometer abusos de poder nem para beneficiar ou prejudicar a uma pessoa ou a um grupo em particular. Só depois de emitida a norma geral é que se abre a possibilidade de atuação do poder executivo, por meio dos atos especiais. O executivo dispõe de meios concretos para agir, mas está igualmente impossibilitado de atuar discricionariamente, porque todos os seus atos estão limitados pelos atos gerais praticados pelo legislativo. E se houver exorbitância de qualquer dos poderes surge a ação fiscalizadora do poder judiciário, obrigando cada um a permanecer nos limites de sua respectiva esfera de competências ${ }^{35}$.

${ }^{35}$ DALLARI, Dalmo de Abreu. Elementos de Teoria Geral do Estado. $19^{a}$ ed. São Paulo: Saraiva, 1995, pp. 184/185. 


\subsection{O controle da Administração pelo Poder Judiciário}

Apesar de a teoria da separação de Poderes ter, desde a origem, previsto que cada um pudesse contrariar os demais, é certo que a limitação de um Poder por outro ainda é vista com muita cautela. Como observa, argutamente, Dalmo Dallari, "a separação de poderes é um dogma, aliado à idéia de democracia, daí decorrendo o temor de afrontá-la expressamente". 36

Esse receio de afrontar o princípio da separação de Poderes tem, inegavelmente, reflexos sobre o controle da Administração - Poder Executivo - pelo Poder Judiciário.

A questão sobre o controle da Administração pelo Poder Judiciário tem especial relevo porque, ao dogma da separação de Poderes, indissociável da idéia de Democracia, somam-se o princípio da inafastabilidade da jurisdição, consagrado no artigo $5^{\circ}$, inciso XXXV, da Constituição Republicana, e o direito de petição, registrado no inciso XXVIV, alínea $a$, do mesmo artigo da Carta Magna.

A isso, acresça-se o fato de que, originalmente, a idéia da separação dos Poderes surgiu como forma de proteção aos direitos individuais, à época vilipendiados pelos Estados Absolutistas ${ }^{37}$ (aliás, não seria exagero afirmar que, então, sequer existam os chamados direitos individuais). Coibir, pois, o acesso do cidadão à Justiça, na defesa de seus direitos contra a Administração, seria um contra-senso histórico.

Dessa constatação se deflui que a contraposição entre o princípio da separação dos Poderes ao do amplo acesso à Justiça e da inafastabilidade do exame do Poder Judiciário só pode ser aparente.

\footnotetext{
${ }^{36}$ DALlARI, Dalmo de Abreu. Elementos de Teoria Geral do Estado. 19a ed. São Paulo: Saraiva, 1995 , p. 186.

${ }^{37}$ DALLARI, Dalmo de Abreu. Elementos de Teoria Geral do Estado. 19a ed. São Paulo: Saraiva, 1995, p. 181: "A teoria da separação de poderes, que através da obra de MONTESQUIEU se incorporou ao constitucionalismo, foi concebida para assegurar a liberdade dos indivíduos".
} 
É importantíssimo, portanto, fixar os limites do controle de um Poder sobre o outro - para o objeto deste trabalho, especificamente, os limites ao controle que o Poder Judiciário exerce sobre a Administração Pública. Marçal Justen Filho anota:

Uma questão essencial é a preservação da autonomia dos órgãos administrativos. A instituição do controle externo não significa a supressão da separação dos poderes nem importa a redução da autonomia no exercício de competências próprias. Isso significa a vedação a que, a pretexto de exercitar controle-fiscalização, um órgão pretenda assumir o exercício de competências reservadas a outro pela Constituição ou lei. ${ }^{38}$

Evidencia-se, pois, que, a pretexto de controlar a Administração, não pode o Judiciário exercer funções que a ela são reservadas. De outra parte, é inegável que o Direito, desde que se concebeu a idéia da separação de Poderes, evoluiu muito. Os direitos fundamentais não são mais apenas os de primeira geração (os chamados direitos individuais), mas também os de segunda (direitos sociais) e terceira geração (direitos coletivos, transindividuais), havendo, ainda, quem mencione a existência de direitos de quarta e quinta geração.

Paulo Bonavides ensina:

Em rigor, o lema revolucionário do século XVIII, esculpido pelo gênio político francês, exprimiu em três princípios cardeais todo o conteúdo possível dos direitos fundamentais, profetizando até mesmo a seqüência histórica de sua gradativa institucionalização: liberdade, igualdade e fraternidade.

Enfim, se nos deparam direitos da primeira, da segunda e da terceira gerações, a saber, direitos da liberdade, da igualdade e da fraternidade, conforme tem sido largamente assinalado, com inteira propriedade, por abalizados juristas.

\section{(...)}

Os direitos da primeira geração ou direitos da liberdade têm por titular o indivíduo, são oponíveis ao Estado, traduzem-se como faculdades ou atributos da pessoa e ostentam uma subjetividade que é seu traço mais característico; enfim, são direitos de resistência ou de oposição perante o Estado.

\section{(...)}

[Os direitos de segunda geração] São os direitos sociais, culturais e econômicos bem como os direitos coletivos ou de coletividades, introduzidos no constitucionalismo das distintas formas de Estado social, depois que germinaram por obra da ideologia e da reflexão antiliberal do

\footnotetext{
${ }^{38}$ JUSTEN FILHO, Marçal. Curso de Direito Administrativo. $1^{\mathrm{a}}$ ed. São Paulo: Saraiva, 2005, p. 745.
} 
século XX. Nasceram abraçados ao princípio da igualdade, do qual não se podem separar, pois fazê-lo equivaleria a desmembrá-los da razão de ser que os ampara e estimula.

$$
\text { (...) }
$$

Dotados de altíssimo teor de humanismo e universalidade, os direitos de terceira geração tendem a cristalizar-se no fim do século XX enquanto direitos que não se destinam especificamente à proteção dos interesses de um indivíduo, de um grupo ou de um determinado Estado. Têm primeiro por destinatário o gênero humano mesmo, num momento expressivo de sua afirmação como valor supremo em termos de existencialidade concreta.

São direitos de quarta geração o direito à democracia, o direito à informação e o direito ao pluralismo. Deles depende a concretização da sociedade aberta do futuro, em sua dimensão de máxima universalidade, para a qual parece o mundo inclinar-se no plano de todas as relações de convivência ${ }^{39}$.

O autor refere, ainda, os chamado direitos de quinta geração, que seriam o direito à paz, "concebido ao pé da letra qual direito imanente à vida, sendo condição indispensável ao progresso de todas as nações, grandes e pequenas, em todas as esferas" ${ }^{40}$.

Neste contexto, é importante que a posição do Poder Judiciário como órgão controlador também evolua.

\section{Pondera Américo Bedê Freire Júnior:}

O legislador não é o único responsável por viabilizar a Constituição. O juiz tem a missão constitucional de impedir ações ou omissões contrárias ao texto, sem que com essa atitude esteja violando a Constituição. O juiz não é mais simples boca da lei, mas intérprete constitucional qualificado, que vai permitir que a Constituição não soçobre numa realidade instável como a que vivemos. Tal postura é ínsita à nova leitura da separação de poderes, adequada ao nosso tempo de globalização e falta de paradigmas. Não podemos pensar a separação de poderes com os fundamentos de uma sociedade que não mais existe, ao contrário, devemos construir um princípio que possa ter aplicação em nossos dias.

Para o cumprimento desse mister, é indispensável vislumbrar, no princípio da separação de funções, não um fim em si mesmo, mas um meio para a efetivação da Constituição, devendo o Judiciário, portanto, nesse novo momento, atuar diretamente na preservação da supremacia da Constituição ${ }^{41}$.

\footnotetext{
${ }^{39}$ BONAVIDES, Paulo. Curso de Direito Constitucional. 23ª ed. São Paulo: Malheiros, 2008, pp. 562/571.

${ }^{40}$ BONAVIDES, Paulo. Curso de Direito Constitucional. 23a ed. São Paulo: Malheiros, 2008, p. 580.

${ }^{41}$ FREIRE JÚNIOR, Américo Bedê. O Controle Judicial de Políticas Públicas. São Paulo: RT, 2005, pp. $44 / 45$.
} 
Juarez Freitas, após discorrer sobre os princípios administrativos - como, por exemplo, da imparcialidade, da moralidade, da publicidade, da boa-fé, da motivação, da participação, da eficiência - propõe que o juiz os tenha como norteadores do controle externo da Administração. Escreve o autor gaúcho:

O controlador, à luz dos princípios elencados, deve evitar manter excessiva dependência quanto a velhos métodos (...), os quais, embora não sejam descartáveis, já não são operacionalmente os mais indicados em face do novo paradigma dialógico, convindo apreciar técnicas de controle endereçadas ao incentivo e à persuasão, em o temor do exame crítico do efeito inercial dos preconceitos herdados. Ao mesmo tempo, deve-se evitar aderir a modismos novidadeiros, sem olvidar que o futuro do controle provavelmente será muito distinto do que foi no passado ${ }^{42}$.

Além disso, diante da evolução da sociedade e da multiplicação de interesses coletivos postos em conflito, muitas vezes, a Administração opera como verdadeira mediadora, optando, concretamente, pelo interesse a ser prestigiado. Por mais este motivo impõe-se ao Judiciário um controle menos tímido, que alcance a própria análise do interesse público protegido. Floriano Peixoto de Azevedo Marques escreve:

A Administração Pública, hoje, é menos uma adjudicadora de direitos previstos na lei e mais um árbitro de interesses legítimos colidentes em cada situação concreta. (...) A importância do controle da discricionariedade não se revela apenas pela necessidade de controlar o preenchimento da lacuna do texto normativo, mas ainda, muitas vezes, pela obrigatoriedade de controlar a discricionariedade na eleição de um determinado interesse público a ser privilegiado na ação estatal em detrimento de outro interesse também de natureza pública, de natureza coletiva, legítimo e albergado numa parcela relevante da sociedade. (...) se a lei não consegue mais prever, a priori, de maneira precisa, os limites da atuação política e cada vez mais é necessária a mediação de interesses públicos, logo, cada vez é mais importante que haja um controle forte, presente, do exercício dessa atividade discricionária. (...) Também é imprescindível que esse controle seja feito pelo Judiciário ${ }^{43}$.

É evidente que não se pode, a pretexto de salvaguardar a lei, os princípios ou a própria Constituição, admitir que o Judiciário faça opções políticas, substituindo-se ao Executivo, porque para isso não tem nem mandato constitucional, nem representação

\footnotetext{
${ }^{42}$ FREITAS, Juarez. O Controle dos Atos Administrativo e os princípios fundamentais. $3^{\mathrm{a}}$ ed. São Paulo: Malheiros, 2004, p. 88.

43 MARQUES, Floriano de Azevedo. Discricionariedade Administrativa e Controle Judicial da Administração. In Processo Civil e Interesse Público. SALLES, Carlos Alberto de (organizador). São Paulo: RT, 2003, pp. 194-195.
} 
democrática. Ou seja: há limites ao controle jurisdicional da Administração. É preciso estudá-los e compreender seu alcance, para, de um lado, não cercear a atividade do Judiciário de órgão fiscalizador da Administração e garantidor da Constituição, e, de outro, não criar um governo de juízes, que não apenas controlam a Administração, mas verdadeiramente administram em seu lugar. 


\subsection{A evolução histórica do controle jurisdicional da Administração}

Antes do estabelecimento de um Estado de Direito, o cidadão não tinha defesa contra os atos do Estado que lhe fossem lesivos. Vigia a teoria da irresponsabilidade, baseada na máxima de que o soberano não poderia errar (the king can do no wrong). Na época, os monarcas eram tidos como verdadeiros representantes de Deus, o que explica que não se concebessem erros seus.

Aos poucos essa situação foi sendo mitigada: primeiro, houve uma separação do Estado em duas faces: o rei e o fisco. $\mathrm{O}$ primeiro praticaria atos de império, não submetidos a controle (era o chamado ius politiae). O segundo praticaria atos de gestão, submetidos ao Direito Civil (ius civile). Foi o que se denominou teoria do fisco, "em consonância com a qual”, explica Maria Sylvia Zanella Di Pietro,

o patrimônio público não pertence ao príncipe nem ao Estado, mas ao fisco, que teria personalidade jurídica de direito privado, diversa da personalidade do Estado, associação política, pessoa jurídica de direito público, com poderes de mando, de império. O primeiro submetia-se ao direito privado e, em consequiência, aos tribunais; o segundo regia-se por normas editadas pelo príncipe, fora da apreciação dos tribunais ${ }^{44}$.

Com a criação do Estado de Direito, notadamente após a Revolução Francesa, criaram-se vários princípios com o fim de proteger os direitos individuais, como o da legalidade, da isonomia e do controle judicial.

Todavia, em um primeiro momento, a legalidade não abrangia toda a atividade administrativa. $\mathrm{O}$ que não dissesse respeito a direitos individuais não era submetido ao princípio da legalidade e continuava fora do controle judicial. Vigorava para a Administração uma vinculação negativa à lei, à semelhança do que acontece hoje em relação aos particulares - a Administração podia fazer tudo o que não estivesse proscrito em lei. Assim o explicou Maria Sylvia Zanella Di Pietro:

\footnotetext{
${ }^{44}$ DI PIETRO, Maria Sylvia Zanella. Discricionariedade Administrativa na Constituição de 1988. $2^{\mathrm{a}}$ ed. Atlas, São Paulo: 2001, p. 18.
} 
Mesmo após a instauração do Estado de Direito, o princípio da legalidade ainda tinha uma configuração bem restrita. Só abrangia aqueles aspectos em que a Administração Pública fosse interferir com os direitos individuais. Entendia-se que a Administração podia fazer tudo o que não fosse proibido por lei: era o mesmo princípio da autonomia de vontade que se aplicava aos particulares ${ }^{45}$.

Assim como os particulares, portanto, a Administração estava submetida ao artigo $5^{\circ}$ da Declaração dos Direitos do Homem e do Cidadão de 1789, segundo o qual "a Lei não pode impedir senão as ações nocivas à sociedade. Tudo o que não for defeso em lei não pode ser impedido, nem ninguém pode ser compelido a fazer o que ela não ordene" ${ }^{\text {" }}$.

O papel do Estado nesse período era de proteger os direitos individuais, sem, no entanto, interferir na vida da sociedade (o Estado mínimo, cuja divisa era laissez faire, laissez passer).

O novo modelo de Estado consolidou-se após a Segunda Guerra Mundial: o Estado social ou providência, de bem-estar (o wellfare state). A sociedade passou a ver que nem todos os homens nascem iguais, sendo necessária a intervenção estatal para assegurar um mínimo de igualdade.

Esse período se caracterizou pelo fortalecimento e burocratização o Poder Executivo. O princípio da legalidade foi ampliado, de forma a abarcar toda a atividade administrativa (vinculação positiva).

Sobre o período observa Maria Sylvia Zanella Di Pietro:

Na realidade, o Estado Social de Direito (ou Estado Legal), sob determinado aspecto, representa um avanço, porque coloca toda a atividade da Administração Pública sob a égide da lei. Mas, vista a questão sob o aspecto da evolução sofrida pela própria idéia de lei, houve um retrocesso, pois ela deixou de ser manifestação da vontade geral do povo e instrumento de garantia dos direitos fundamentais, na medida em que o Poder Legislativo deixou de ser o único a editar normas legais, assumindo uma posição de dependência em relação ao Executivo, além

45 DI PIETRO, Maria Sylvia Zanella. Discricionariedade Administrativa e Controle Judicial da Administração. In Processo Civil e Interesse Público. SALLES, Carlos Alberto de (organizador). São Paulo: RT, 2003, p. 182.

${ }^{46}$ Art. 5. La Loi n'a le droit de défendre que les actions nuisibles à la Société. Tout ce qui n'est pas défendu par la Loi ne peut être empêché, et nul ne peut être contraint à faire ce qu'elle n'ordonne pas. (tradução livre) 
de que passou a promulgar lei em sentido apenas formal, desvinculadas da idéia de justiça ${ }^{47}$.

A sociedade continuou a evoluir, tendo surgido, por exemplo, os direitos transindividuais, que exigiram novas formas de atuação do Estado e também novos meios de acesso ao Judiciário.

Hoje se fala em Estado Social e Democrático de Direito - expressão consagrada, apesar do aparente pleonasmo que encerra, pois não se imagina a existência de Estado Democrático que não seja de Direito -, caracterizado pela maior participação popular na Administração e pela valoração dos princípios. Maria Sylvia Zanella Di Pietro anota:

Mais um avanço ocorreu a partir do chamado Estado Democrático de Direito em que a lei adquiriu um conteúdo axiológico, já que passou a interessar não apenas pelo seu aspecto formal, não apenas porque ela contém uma ordem, mas porque ela deve conter valores, ela deve atender objetivos de justiça e eqüidade ${ }^{48}$.

À ampliação do papel do Estado correspondeu uma diminuição no âmbito da discricionariedade, com a correspondente ampliação da legalidade. Assim, aumentou o espectro submetido a exame pelo Poder Judiciário.

Importante ressaltar que, de início, o exame judicial do ato administrativo somente se restringia aos aspectos formais deste (competência e forma). Dois grandes avanços na matéria foram fruto de elaboração pretoriana do Conselho de Estado Francês: a teoria dos motivos determinantes, segundo a qual os falsos motivos, quando declinados, fulminam de nulidade o ato administrativo, e a teoria do desvio de poder, pela qual é nulo ato praticado com vistas a fim diverso do previsto na regra de competência.

Maria Sylvia Zanella Di Pietro bem resumiu esta evolução:

Analisada a evolução sob o ponto de vista da discricionariedade, houve uma primeira fase de imunidade jurisdicional, correspondente ao

\footnotetext{
${ }^{47}$ DI PIETRO, Maria Sylvia Zanella. Discricionariedade Administrativa na Constituição de 1988. $2^{\mathrm{a}}$ ed. Atlas, São Paulo: 2001, p. 38.

${ }^{48}$ DI PIETRO, Maria Sylvia Zanella. Discricionariedade Administrativa e Controle Judicial da Administração. In Processo Civil e Interesse Público. SALLES, Carlos Alberto de (organizador). São Paulo: RT, 2003, p. 183.
} 
período em que o poder discricionário era considerado um poder político (...). Depois vem uma segunda fase em que o Poder Judiciário passou a controlar os atos da Administração, porém de forma limitada, porque praticamente apreciava os vícios de competência e de forma; o controle era o mais amplo possível. Mais um avanço e se elaborou a teoria do desvio de poder e, logo em seguida, a teoria dos motivos determinantes. Com a construção dessas duas teorias, elaboradas pelos órgãos da jurisdição administrativa do sistema francês, houve um grande avanço em termos de controle porque dois aspectos do ato administrativo - a finalidade e o motivo -, que antes não admitiam apreciação judicial por não constituírem elementos integrantes do ato administrativo, passaram a ser assim considerados; em consequiência, passaram a ser objeto de

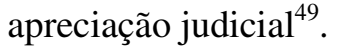

49 DI PIETRO, Maria Sylvia Zanella. Discricionariedade Administrativa e Controle Judicial da Administração. In Processo Civil e Interesse Público. SALLES, Carlos Alberto de (organizador). São Paulo: RT, 2003, p. 183. 


\subsection{Discricionariedade e vinculação}

Dentro do tema do controle jurisdicional dos atos da Administração, revela-se importantíssimo o estudo do mérito administrativo - que, tradicionalmente, é entendido como aquele núcleo do ato insindicável pelo Poder Judiciário. José dos Santos Carvalho Filho leciona: "Pode-se, então, considerar mérito administrativo a avaliação da conveniência e da oportunidade relativas ao motivo e ao objeto, inspiradoras da prática do ato discricionário" ${ }^{\circ 0}$.

Para delimitar o mérito do ato, impõe-se, então, analisar a discricionariedade administrativa.

Para que o controle jurisdicional da Administração seja correto - vale dizer, nem excessivo, invadindo seara que constitucionalmente não lhe cabe, nem reduzido, permitindo desmandos do Poder Público -, é preciso que a discricionariedade seja corretamente compreendida. Como bem observa Maria Sylvia Zanella Di Pietro,

as dificuldades em entender onde termina a legalidade e começa a discricionariedade administrativa levam o Poder Judiciário, até por comodismo, a deter-se diante do mal definido "mérito" da atuação administrativa, permitindo que prevaleça o arbítrio administrativo onde deveria haver discricionariedade exercida nos limites estabelecidos em $\mathrm{lei}^{51}$.

A resistência contra a concessão de poderes discricionários à Administração decorre de sua freqüente confusão com a arbitrariedade. Não se pode olvidar, porém, que ela é patologia, curável, em nosso sistema jurídico, mediante a intervenção do Poder Judiciário.

Escrevendo sobre a discricionariedade das agências americanas, Richard. J. Pierce Jr. pontifica que "O governo não pode operar sem agências que exerçam poder

\footnotetext{
${ }^{50}$ CARVALHO FILHO, José dos Santos. Manual de Direito Administrativo. $18^{\text {a }}$ ed. Rio de Janeiro: Lumen Iuris, 2007, p. 113.

${ }^{51}$ DI PIETRO, Maria Sylvia Zanella. Discricionariedade Administrativa na Constituição de 1988. $2^{\mathrm{a}}$ ed. Atlas, São Paulo: 2001, p. 38
} 
discricionário. Cada Congresso e cada Presidente reconheceu esta verdade básica" ${ }^{\text {}}$. Na sequiência, aponta três problemas que podem decorrer do tratamento legal da discricionariedade:

Primeiro, conferir muita discrição para um indivíduo ou instituição cria o potencial para (...) o abuso de discrição. Muitas doutrinas administrativas são uma resposta para este conhecido problema. Os outros dois tipos de problema não têm recebido a atenção merecida. $\mathrm{O}$ segundo problema é a não intencional transferência de discrição. Tentar limitar a discrição freqüentemente apenas transfere a discrição de um indivíduo ou instituição para outro. Comumente, a alocação preexistente do poder discricionário era melhor que a nova. (...) O terceiro problema é o poder discricionário inadequado. Os indivíduos e órgãos com importantes responsabilidades devem ter considerável discrição para exercer suas responsabilidades efetivamente. A discrição inadequada provavelmente é um problema maior que a discrição excessiva. ${ }^{53}$

O autor sustenta:

ao menos parte da solução do problema da discricionariedade das agências deve residir na revisão judicial dos atos das agências. As cortes podem confinar as agências a limites permissivos constitucionais na medida em que a Constituição provê padrões jurídicos. (...) As cortes também podem reduzir o potencias das agências e empregados de agências de empregar o exercício do poder discricionário para propósitos arbitrários ou proibidos.

Refere que o Congresso atribuiu, expressamente, esse papel às cortes ao lhes permitir rever os atos das agências "found to be arbitrary, capricious, an abuse of discretion", ou seja, os arbitrários, caprichosos ou abusivos.

Todavia, alerta que, assim como a revisão judicial pode ser uma solução (Judicial Review as a Potential Solution), também pode ser parte do problema (Judicial Review as a Part of the Problem). Explica:

A revisão judicial pode ser fonte de discrição excessiva assim como meio de limitar a discrição. As cortes também podem causar este não pretendido efeito de duas maneiras. Primeiro, na medida em que as

\footnotetext{
${ }^{52}$ PIERCE JR., Richard J. Administrative Law. vol. III. 4a ed. New York: Aspen Publishers, 2002, p. 1.227 (tradução livre).

${ }^{53}$ PIERCE JR., Richard J. Administrative Law. vol. III. 4a ed. New York: Aspen Publishers, 2002, pp. 1.227/1.228 (tradução livre).

${ }^{54}$ PIERCE JR., Richard J. Administrative Law. vol. III. 4ª ed. New York: Aspen Publishers, 2002, pp. 1.234 (tradução livre).
} 
doutrinas de direito administrativo têm o efeito de conferir às cortes de revisão discrição para resolver casos idênticos de maneiras diversas, o problema da discrição é simplesmente transferido da agência para os juízes. Segundo, na medida em que as cortes de revisão criam obstáculos para o uso das agências de regras para limitar sua própria discricionariedade e a de seus empregados, as cortes prejudicam a habilidade das agências de limitar a discricionariedade no nível da agência e dos empregados ${ }^{55}$.

Embora a crítica pareça, integralmente, transportável para o nosso sistema jurídico - já que, com efeito, o Judiciário pode julgar casos idênticos de maneira diferente, o que, de relance, poderia aparentar uma "transferência" da discricionariedade - o fato é que a possibilidade de decisões divergentes é da essência do sistema processual vigente e não se limita aos casos que envolvem discricionariedade. Mesmo os pleitos que se referem a leis vinculadas, bem como as ações cujos objetos sejam atinentes a outros campos do Direito como o Direito Penal ou de Família, por exemplo - estão submetidos ao mesmo "problema". Vale dizer: o que possibilita a ocorrência de decisões díspares para casos similares não é a transferência de discricionariedade, mas a forma como foi estruturado nosso sistema processual.

Ademais, é de todo indesejável que a discricionariedade seja transferida para o Poder Judiciário. O que não é possível é que, deparando-se diante de um ato praticado com poderes discricionários, abstenha-se o juiz de examiná-lo sob esse pretexto. É preciso verificar se a discricionariedade foi corretamente exercida - do contrário, já foi dito, há arbitrariedade e, conseqüentemente, ilegalidade.

Assim, é indispensável estudar a discricionariedade, compreendendo sua extensão.

A doutrina, de maneira geral, entende haver discricionariedade sempre que o administrador possa, diante de um caso concreto, optar entre mais de uma solução, todas admissíveis perante a lei.

Celso Antonio Bandeira de Mello combate a idéia de que haja um poder discricionário, preferindo a expressão dever discricionário. Isso porque os poderes administrativos são meramente instrumentais, e não se justificam senão em função dos

${ }^{55}$ PIERCE JR., Richard J. Administrative Law. vol. III. 4a ed. New York: Aspen Publishers, 2002, p. 1.236 (tradução livre). 
interesses a que servem - genericamente, o interesse público. Portanto, o alcançamento da finalidade pública - ou, antes, a busca desse fim - não é uma opção, mas a única via que se coloca ao administrador. Dá-se o que os jurisdoutrinadores italianos chamam de doverosità, significando a sujeição ao dever de perseguir o bem comum ${ }^{56}$.

No seu magistério, discricionariedade

é a margem de liberdade que remanesça ao administrador para eleger, segundo critérios consistentes de razoabilidade, um, dentre pelo menos dois comportamentos cabíveis, perante cada caso concreto, a fim de cumprir o dever de adotar a solução mais adequada à satisfação da finalidade legal, quando, por força da fluidez das expressões da lei ou da liberdade conferida no mandado, dela não se possa extrair objetivamente, uma solução unívoca para situação vertente ${ }^{57}$.

Maria Sylvia Zanella Di Pietro define a discricionariedade administrativa como "a faculdade que a lei confere à Administração para apreciar o caso concreto, segundo critérios de oportunidade e conveniência, e escolher uma dentre duas ou mais soluções, todas válidas perante o direito" ${ }^{\text {. }}$.

Muitos dos doutrinadores põem em relevo um aspecto importante desta margem de discricionariedade: sua justificativa, seu fundamento. Nessa orientação, diz-se que quando a lei, em lugar de prever uma conduta única e vinculante ao agente diante de situações de fato, prévia e perfeitamente definidas e objetivamente aferíveis, lhe confere uma margem de atuação, concebe-a com um único escopo - permitir que se adote a medida que melhor atinja a finalidade normativa (isto é, a finalidade eleita pelo legislador como a mais adequada ao bem comum na norma específica a ser aplicada).

Celso Antonio Bandeira de Mello escreve:

A outorga da discrição vem a ser, precisamente, o meio pelo qual a lei busca assegurar-se de que sua aplicação far-se-á sempre de maneira a atender-lhe a finalidade de modo perfeito. (...) Assim, quando o

\footnotetext{
${ }^{56}$ BANDEIRA DE MELLO, Celso Antônio. Discricionariedade e Controle Jurisdicional, $2{ }^{a}$ ed., São Paulo: Malheiros, 2003, pp. 14/15.

${ }^{57}$ BANDEIRA DE MELLO, Celso Antônio. Discricionariedade e Controle Jurisdicional, $2^{a}$ ed., São Paulo: Malheiros, 2003, p. 48.

${ }^{58}$ DI PIETRO, Maria Sylvia; Discricionariedade Administrativa na Constituição de 1988; $2^{\mathrm{a}}$ ed.; Atlas; SP: 2001, p. 67.
} 
legislador acredita que, de toda sorte, pode predeterminar completamente o comportamento administrativo, sem riscos ou com menosprezáveis riscos para o perfeito atendimento dos fins que tem em mira, regula a conduta com altíssimo grau de vinculação. Pelo contrário, quando considera que a melhor providência, a única que efetivamente almeja - única apta a exprimir com exemplar fidelidade o escopo legal reclama uma análise valorativa das situações concretas confere discrição. E o faz justamente por entender que o administrador, cercado dos fatos e confrontado com suas feições peculiares, poderá superiormente identificar e adotar a conduta devida, isto é, aquela - e tão somente aquela - que atenderá com precisão capilar a finalidade que a lei almeja satisfazer. Em uma palavra: quando existir discrição, a autoridade administrativa estará obrigada a eleger a providência que seja plenamente adequada ao cumprimento da finalidade da lei e não qualquer das providências abstratamente comportadas pela regra aplicanda. ${ }^{59}$

Edmir Netto de Araújo, por sua vez, entende que raramente a lei confere expressamente a discrição ao administrador; o que ela faz é criar, propositalmente, uma margem de indeterminação, na qual reside a discricionariedade. E leciona:

a lei, propositadamente, deixou este aspecto indeterminado, para que o administrador integre a vontade da lei com sua participação direta, ao decidir qual o melhor meio de satisfazer o interesse público que a norma legal visa realizar. ${ }^{60}$

Daí porque, segundo lição de Afonso Rodrigues Queiró,

a atividade administrativa não difere da atividade de grau imediatamente superior - a legislativa ordinária - senão em que os sujeitos que a realizam são livres de juntar à lei alguma coisa de extra-jurídico, um nouvel apport, um aliquid novi, já que se não consegue uma rígida execução da norma heterônoma. O poder discricionário aparece, assim, como necessário elemento na gradual formação do direito, ou das normas jurídicas; é ele que as torna sucessivamente mais concretas ${ }^{61}$.

Com efeito, diante das peculiaridades que informam a situação fática que inspira a medida, é mais fácil encontrar a solução consentânea com a finalidade pública específica a

\footnotetext{
${ }^{59}$ BANDEIRA DE MELLO, Celso Antônio. Legalidade - Discricionariedade - Seus Limites e Controle. RDP n'86, pp. 44/45.

${ }^{60}$ ARAÚJO, Edmir Netto de. Curso de Direito Administrativo. $1^{\text {a }}$ ed. São Paulo: Saraiva, 2005, p. 450.

${ }^{61}$ QUEIRÓ, Afonso Rodrigues. A Teoria do "Desvio de Poder" em Direito Administrativo. RDA 6/41, Rio de Janeiro, p. 44.
} 
que visa a norma. É impossível, para o legislador, prever a multiplicidade de ocorrências concretas capazes de interferir no resultado almejado.

Sendo assim, parece adequado conceituar a discricionariedade como a margem de liberdade, deixada pelo legislador ao administrador, para que este, diante do caso concreto e inspirado pelos princípios gerais de direito e por critérios de razoabilidade e moralidade, escolha, dentre as diversas soluções, juridicamente possíveis, a que lhe pareça melhor atender à finalidade pública a que visa a norma.

Há vinculação, ao contrário, quando inexiste referida margem de liberdade. Segundo Edmir Netto de Araújo,

Deixar apenas uma solução possível ao administrador público, sem qualquer liberdade de escolha dos meios, da ocasião ou da conveniência de, através de ato administrativo, procurar atingir interesse público objetivado, é o que se chama vinculação ${ }^{62}$.

Não é difícil perceber que, quanto menor a margem de atuação livre da Administração, mais amplo o controle exercido pelo Poder Judiciário. Nos atos vinculados, todos os aspectos do ato podem ser sindicados.

E é justamente nesse espaço de livre apreciação que reside o mérito do ato administrativo. Não se fala em mérito quando o ato é integralmente vinculado, pois, nesses casos, o legislador já fez, antecipadamente, a opção quanto ao motivo e o objeto do ato, incumbindo ao administrador, tão-somente, aplicar a lei.

Quando há uma margem de discricionariedade, o administrador faz sua escolha, sua opção, dentre as legalmente possíveis. E nessa escolha consiste o mérito administrativo que, em princípio, está fora do âmbito do controle do Poder Judiciário.

Nesse sentido, há muitas decisões judiciais. Citem-se, ad exemplum:

Ato Administrativo - Mérito - Reenquadramento de Professores Apreciação pelo Judiciário - Inadmissibilidade. Recurso especial. Ato Administrativo. Mérito. A tripartição dos poderes enseja a cada um

\footnotetext{
${ }^{62}$ ARAÚJO, Edmir Netto de. Curso de Direito Administrativo. $1^{\text {a }}$ ed. São Paulo: Saraiva, 2005, p. 450.
} 
decidir, no âmbito discricionário, a oportunidade e conveniência. O mérito do ato é definido, no caso dos autos, pelo Executivo. Ao Judiciário é vedado substituir o administrador. $\mathrm{O}$ exame da legalidade, além do aspecto formal, compreende também a análise dos fatos levados em conta pelo Executivo. Inadequado, porém, simplesmente, alterar a opção daquele poder. (STJ - REsp 4.526 - 2 ${ }^{\mathrm{a}}$ Turma - Rel. Min. Vicente Cernicchiao - j. 5/9/1990)

Ato Administrativo - Reexame do Judiciário - Insuscetibilidade. Os modernos princípios de acesso ao Judiciário recomendam a aplicação do princípio da fungibilidade dos recursos. $\mathrm{O}$ aspecto formal não deve ser aplicado de modo intransigente. $\mathrm{O}$ ato administrativo, quanto ao mérito, é insusceptível de reexame do Judiciário, em decorrência da separação dos poderes. A discricionariedade do ato não se confunde com ilegalidade. (STJ - REsp $69.735-6^{\mathrm{a}}$ Turma - Rel. Min. Luiz Vicente Cernicchiaro - j. 15.04.96)

Evidentemente, o mérito administrativo não impede que o Poder Judiciário anule o ato, se identificar alguma ilegalidade. Foi o que decidiu o Supremo Tribunal Federal:

Controle jurisdicional dos atos administrativos, quando ilegais ou abusivos. Possibilidade. Não viola o princípio da separação dos Poderes a anulação de ato administrativo que fere a garantia constitucional do contraditório e da ampla defesa. Precedente: RE 259.335-Agr., Rel. Min Maurício Corrêa; e 170.782, Rel. Min. Moreira Alves. Agravo desprovido. (STF - AI 463.646 Agr/BA - $1^{\text {a }}$ Turma - Rel. Min. Carlos Britto - D.O.U. 27.5.2005)

Para alargar o controle jurisdicional dos atos administrativos - que era, de início, muito tímido - foram desenvolvidas teorias, sobretudo pelo Conselho de Estado Francês. Trata-se da teoria dos motivos determinantes e do desvio de poder. 


\subsection{Teoria do desvio de poder}

Uma das teorias que permite ao Judiciário uma maior amplitude do controle do ato administrativo é a teoria do desvio de poder.

A origem da teoria do desvio de poder é francesa. Em 1864, no julgamento do arrêt Lesbas, o Conselho de Estado admitiu ser possível atacar um ato viciado por desvio de poder.

A expressão "desvio de poder" está amplamente consagrada na doutrina e jurisprudência. Mas, na verdade, o que caracteriza este vício é um desvio de finalidade.

Com efeito, estando a Administração submetida aos limites da lei, regida que é pelo princípio da legalidade, deve buscar, sempre, a consecução da finalidade eleita pela lei para cada ato administrativo. Isto é, a par do interesse público, que deve ser sempre almejado e perseguido pela Administração, o legislador ainda impõe a finalidade que cada ato específico deve atender.

Isso porque, conforme explica Celso Antônio Bandeira de Mello,

No Estado de Direito quer-se o governo das leis e não o governo dos homens, consoante a clássica assertiva proveniente do Direito inglês. Isto significa que é ao Poder Legislativo que assiste o encargo de traçar os objetivos públicos a serem perseguidos e de fixar os meios e os modos pelos quais hão de ser buscados, competindo à Administração, por seus agente, o mister, o dever, de cumprir dócil e fielmente os desiderata legais, segundo os termos estabelecidos em lei. Assim, a atividade administrativa encontra na lei tanto seus fundamentos quanto seus limites ${ }^{63}$.

Não é difícil entender o porquê. A Administração, em rigor, gere os bens que são de todos. A única forma pela qual o povo, titular desses bens e direitos por ela administrados, pode determinar como deve ser a gestão dos bens públicos e pelas leis, editadas por seus representantes, democraticamente eleitos. É neste sentido a lição de Ruy Cirne Lima:

${ }^{63}$ BANDEIRA DE MELLO, Celso Antônio. Discricionariedade e Controle Jurisdicional, 2a ed., São Paulo: Malheiros, 2003, p. 49. 
Como o Estado tem por finalidade, por meio da atividade administrativa, realizar a utilidade pública, está presente no direito público o interesse público. No exercício desta atividade, o Estado atua como ente soberano, que se relaciona nesta condição com os administrados. De outra parte, o Estado, na procura do bem comum, atua como mandatário da sociedade, e é titular de direitos e obrigações de natureza especial, que estão definidos pelo direito público ${ }^{64}$.

Vale dizer, dada a posição especialíssima da Administração, está ela submetida a um regime de prerrogativas e restrições. Assim, a Administração, como verdadeira mandatária do titular dos bens e direitos geridos - o povo - tem sua atuação, integralmente, submetida ao princípio da legalidade, aí incluídos os fins que deve perseguir cada vez que atuar.

Assim, por exemplo, o Decreto-Lei 3.365, de 21 de junho de 1941, que trata da desapropriação por utilidade pública. O diploma normatiza este tipo de desapropriação, mencionando, em rol não exaustivo, diversas hipóteses de utilidade pública aptas a ensejar um Decreto expropriatório por parte do Poder Público: a segurança nacional, a salubridade pública, a exploração e conservação dos serviços públicos, a execução de planos de urbanização etc ${ }^{65}$. Se um agente público iniciar um procedimento expropriatório, não para ultimar quaisquer desses fins, mas para valorizar terrenos contíguos ao expropriando ou ainda para prejudicar desafeto seu, ocorrerá o vício do desvio de poder.

Jean Rivero apresenta a seguinte definição do desvio de poder:

Ao contrário do particular, que escolhe livremente o fim dos seus atos, a Administração vê imposto o fim que a sua actividade deve prosseguir. De modo geral, só deve exercer as suas competências com vista à satisfação do interesse público, em virtude de um princípio geral do direito. De modo mais particular, os textos assinalaram a certas competências um fim preciso: os poderes de política têm por finalidade assegurar a manutenção da ordem, o processo de alinhamento tem por finalidade fixar os limites da via pública etc.

O desvio de poder é o vício que enferma um acto pelo qual a Administração, não observando essas regras, prosseguiu um fim diferente

${ }^{64}$ LIMA, Ruy Cirne. Princípios de Direito Administrativo. $7^{\mathrm{a}}$ ed., atualizada por Paulo Alberto Pasqualini, Sâo Paulo: Malheiros, 2007, pp.33/34.

${ }^{65}$ Decreto-lei 3.365/41, art. $5^{\circ}$. 
daquele que o direito lhe determinava, desviando assim do seu fim legal o poder que lhe estava confiado ${ }^{66}$.

Mais sintética é a definição proposta por Celso Antonio Bandeira de Mello: "entende-se por desvio de poder a utilização de uma competência em desacordo com a finalidade que lhe preside a instituição"67.

No Brasil, há uma definição legal do desvio de finalidade, constante da Lei de Ação Popular. Na dicção legal, "desvio de finalidade se verifica quando o agente pratica ato visando a fim diverso daquele previsto, explícita ou implicitamente, na regra de competência" (art. $2^{\circ}$, parágrafo único, $e$ ).

Como explica Gilles Lebreton,

Um ato está maculado de desvio de poder quando seu autor o praticou com um objetivo psicológico diferente daquele previsto pelos textos. Duas hipóteses devem ser distinguidas: a) Primeira hipótese: praticando o ato, a autoridade não perseguiu nenhum fim de interesse geral (...) b) Segunda hipótese: praticando o ato, a autoridade perseguiu um objetivo de interesse geral diferente daquele a que deveria visar ${ }^{68}$.

${ }^{66}$ RIVERO, Jean. Ehrdaedt Soares, Rogério (trad.). Direito Administrativo. Coimbra: Almedina, 1981, pp. 289-290.

${ }^{67}$ BANDEIRA DE MELLO, Celso Antônio. Discricionariedade e Controle Jurisdicional, $2^{\mathrm{a}}$ ed., São Paulo: Malheiros, 2003, p. 56.

${ }^{68}$ LEBRETON, Gilles. Droit Administratif Général. $4^{\mathrm{a}}$ ed. Paris: Dalloz, 2007, pp. 476/477 (tradução livre). 


\subsubsection{O desvio de poder alheio a qualquer interesse público}

A forma mais usual de desvio de poder é, sem dúvida, o alheio a qualquer interesse público. O agente pratica o ato não animado pelo atendimento do interesse público, mas para extrair vantagem pessoal, beneficiar ou prejudicar terceiro, vingar-se etc.

Celso Antonio Bandeira de Mello comenta:

A vida administrativa brasileira, desgraçadamente, pode oferecer inúmeros exemplos desta nefanda modalidade de desvio de poder, muito comum por razões sectárias. Tanto assim é, que se põe - como comprovação indireta - a contigência legislativa de vedar, drasticamente, admissões, exonerações e remoções ex officio no período pré e pós eleitoral. Há nisto um explícito reconhecimento de que ditas práticas, sobremodo vitandas, existiriam aos bolhões não fora pelas cautelas legislativas. Se estas não conseguem evitá-las, podem ao menos restringir em parte suas ocorrências. Coibindo-as liminarmente nas épocas em que os ânimos políticos estão mais encandecidos, guardam a expectativa (tantas vezes frustrada) de que, fora deles, com o arrefecimento das paixões sectárias, os administradores se façam mais contidos ${ }^{69}$.

O vício do desvio de poder deve ser averiguado a partir da intenção do agente - o que torna sua prova bastante difícil.

Vale acrescentar que, conforme pontifica José dos Santos Carvalho Filho,

Segundo alguns especialistas, o desvio de finalidade seria um vício objetivo, consistindo no distanciamento entre o exercício da competência e a finalidade legal e, por tal razão, irrelevante se revelaria a intenção do agente. Não endossamos esse pensamento. Na verdade, o fato em si de estar a conduta apartada do fim legal não retrata necessariamente o desvio de finalidade, vez que até por erro ou ineficiência pode o agente cometer ilegalidade. O desvio pressupõe o animus, vale dizer, a intenção deliberada de ofender o objetivo de interesse público que lhe deve nortear o comportamento. Sem esse elemento subjetivo, haverá ilegalidade, mas não propriamente desvio de finalidade ${ }^{70}$.

${ }^{69}$ BANDEIRA DE MELLO, Celso Antônio. Discricionariedade e Controle Jurisdicional, $2^{\mathrm{a}}$ ed., São Paulo: Malheiros, 2003, pp. 62-63.

${ }^{70}$ CARVALHO FILHO, José dos Santos. Manual de Direito Administrativo. $18^{\mathrm{a}}$ ed. Rio de Janeiro: Lumen Iuris, 2007, p. 110. 
Esse posicionamento parece, de fato, mais acertado. $\mathrm{O}$ afastamento não-intencional da finalidade legal não equivale ao desvio de poder. Aliás, na legislação pátria, a expressão "visando a", empregada pela Lei da Ação Popular não deixa margem a dúvidas: impõe-se perquirir o elemento subjetivo do agente.

Como exemplos de desvio de poder alheio a qualquer finalidade de interesse público retirados da jurisprudência francesa, Gilles Lebreton menciona a hipótese de um Prefeito que impediu a abertura de uma danceteria, durante a semana, para impedi-la de concorrer com seu negócio de bebidas (desvio de poder em interesse próprio); o caso da criação, por uma autoridade administrativa, de uma escola de tapeçaria, com o fim de confiar-lhe a direção a uma amiga (desvio de poder em interesse de terceiro); a recusa de uma federação em convocar um atleta que havia dirigido críticas a seus dirigentes (desvio de poder movido por vingança ou animosidade $)^{71}$.

${ }^{71}$ LEBRETON, Gilles. Droit Administratif Général. 4ª ed. Paris: Dalloz, 2007, pp. 476. 


\subsubsection{O desvio de poder visando a interesse público distinto do previsto em lei}

Atingir o interesse público é sempre uma finalidade da Administração. Pode-se dizer que se trata de uma finalidade em sentido amplo, que se aplica a todos os atos administrativos. Ao lado desta, porém, haverá outra, em sentido estrito, que a lei impõe a cada ato.

Ensina Marçal Justen Filho:

O instituto do desvio de poder se alicerça sobre a existência de destinação determinada para as competências administrativas. Essas competências têm destinação que pode ser mais ampla ou menos ampla, mas sempre haverá limite. Haverá vício se uma competência for desnaturada, sendo utilizada para fins diversos daqueles que a norma estabeleceu $^{72}$.

Vale dizer - se o agente pratica um ato com escopo de atender a uma finalidade pública que não a prevista na norma de competência há, também, desvio de poder independentemente, até, da sua boa-fé. Como explica Celso Antonio Bandeira de Mello,

Não importa que o objetivo público visado pudesse ser alcançado através de outro ato, correspondente a outra competência. Se as condições do exercício de uma e outra eram distintas, a Administração não pode, em função de vantagens ou facilidades, manipular uma dada competência quando seria o caso de utilização da outra. Nestas hipóteses, diz-se, no direito francês, que ocorre um "détournement de procedure", isto é, um desvio de procedimento ${ }^{73}$.

Exemplo clássico de desvio de poder com vistas a atendimento de outra finalidade de interesse público é a remoção, ex officio, de servidor que praticou uma falta grave com o objetivo de puni-lo. A remoção não tem caráter punitivo.

Dilles Lebreton escreve:

O exemplo mais típico é fornecido pelo arrêt Pariset (CE 26.11.1875 Pariset GAJA). Neste caso, um prefeito havia determinado o

\footnotetext{
72 JUSTEN FILHO, Marçal. Curso de Direito Administrativo. $1^{\text {a }}$ ed. São Paulo: Saraiva, 2005, p. 265.

${ }^{73}$ BANDEIRA DE MELLO, Celso Antônio. Discricionariedade e Controle Jurisdicional, $2^{\mathrm{a}}$ ed., São Paulo: Malheiros, 2003, p. 65.
} 
fechamento de uma fábrica de fósforos, utilizando seu poder de polícia administrativa especial sobre os estabelecimentos perigosos. Mas na realidade, seu objetivo não era o de assegurar, como ele fazia crer, o interesse geral de segurança previsto pelos textos para a utilização deste poder, mas servir ao interesse geral das finanças do Estado: sua decisão tinha, com efeito, o objetivo de evitar que o Estado desembolsasse a indenização decorrente da privatização, por uma lei de 1872, das fábricas de fósforos; logicamente, ela foi então anulada ${ }^{74}$.

${ }^{74}$ LEBRETON, Gilles. Droit Administratif Général. 4a ed. Paris: Dalloz, 2007, p. 477 (tradução livre). 


\subsubsection{O desvio de poder por omissão}

Sendo o desvio de poder vício ligado à intenção do agente, para que ele se caracterize por omissão, é preciso que esta tenha sido deliberada, e que tenha o agente público objetivado finalidade distinta da legalmente prevista.

Celso Antonio Bandeira de Mello angariou como exemplo de desvio de poder por omissão a hipótese versada em acórdão proferido pelo Tribunal de Justiça de São Paulo:

Sirva de exemplo uma curiosa hipótese ocorrida em um Município de São Paulo. Dado Prefeito firmou contrato de prestação de serviço com certa empresa. Nele se estipulou que o contrato se prorrogaria automaticamente por igual período se a Prefeitura, ao cabo do prazo contratual, deixasse de declará-lo findo. Vencido o prazo, o Prefeito que à época já estava à beira da conclusão de seu mandato - omitiu-se em dar por encerrado o contrato, propiciando destarte sua prorrogação. Quinze dias depois, às vésperas de deixar o cargo, rescindiu o contrato sob mera alegação de conveniência administrativa, com o que ensejou a operatividade de cláusula contratual que previa indenização ao contratante por todo o período remanescente (28 meses) tornado frustro em caso de rescisão unilateral. Em rigor, foram dois comportamentos administrativos (um omissivo e um comissivo) que geraram o benefício para o contratado. Manifestamente - como resultado da seqüência dos fatos - não havia interesse na continuidade do vínculo contratual. $O$ segundo ato, a rescisão unilateral, era necessário para benefício do contratante e valeu como uma demonstração de que o comportamento anterior (a omissão em dar por extinto o contrato) é que ocorrera em desacordo com o interesse público. A extinção do contrato já era conveniente ao termo do vínculo precedente. Esta conjugação de uma omissão e um ato, compondo um quadro de favoritismo, não prosperou, porque o Tribunal de Justiça do Estado, em acórdão proferido pela Nona Câmara de Apelação Cível no 111/645-2, sendo relator o desembargador Jorge Celidonio, que denegou a indenização postulada pelo contratado, fundamentando-se na teoria do desvio de poder ${ }^{75}$.

Impõem-se, portanto, para a caracterização do desvio de poder por omissão duas condições: a) que a lei atribua à omissão uma consequiência jurídica; b) que o agente se omita, deliberadamente, com o objetivo de atingir, com sua inação, finalidade diversa da prevista em lei.

\footnotetext{
${ }^{75}$ BANDEIRA DE MELLO, Celso Antônio. Discricionariedade e Controle Jurisdicional, $2^{\mathrm{a}}$ ed., São Paulo: Malheiros, 2003, p. 76.
} 
O exemplo colhido por Celso Antonio Bandeira de Mello foi tirado de uma situação na qual o silêncio da Administração tinha uma conseqüência, expressamente prevista em lei - a prorrogação do contrato. E o silêncio foi guardado com fim diferente daquele previsto pela lei (ou seja: não para permitir a continuidade de um contrato cuja prorrogação fosse interesse da Administração, mas para, posteriormente, garantir a indenização do contratado). 


\subsection{Teoria dos motivos determinantes}

Nos atos administrativos tem sobrelevada importância o motivo. Tanto assim que a doutrina aponta como um dos princípios de Direito Administrativo o da motivação. Com efeito, a motivação permite ao administrado saber o porquê de uma determinada decisão da Administração. Também é uma forma de a Administração prestar contas de sua atuação à sociedade como um todo - até porque, como se mencionou, com menção ao entendimento de Ruy Cirne Lima, a Administração gere bens alheios.

\section{Esclarece Edmir Netto de Araújo:}

Isto significa o seguinte: diante da ocorrência de evento certo material ou fato jurídico, ou da constatação de determinada situação jurídica, o sujeito (Estado, por seus governantes, legisladores, dirigentes, agentes administrativos que podem ser a mesma pessoa que vai praticar o ato, ou outras) compara essa circunstância com um interesse público concretamente existente (prestação regular e contínua de um serviço público, p.ex.) e conclui que se impõe a tomada de certa providência (ato administrativo) para a realização prática e operante daquele interesse público concreto.

Esse impulso de vontade decorrente do binômio evento-situação mais interesse público concreto é nada mais que o motivo, e a realização efetiva do interesse (prestação efetiva daquele serviço público) é nada menos que a finalidade: entre os dois se colocam os pressupostos e formalidades intermediários, a intervenção do agente público competente (que não é necessariamente quem detectou a necessidade da prática de um ato) fazendo uma declaração de vontade sobre certo objeto referente ao motivo, em certa forma adequada para conseguir aqueles efeitos práticos, e os eventuais fatores de eficácia que darão operacionalidade à declaração. $^{76}$

A teoria dos motivos determinantes abriu para o Judiciário a possibilidade de examinar os fatos que ensejaram a prática do ato administrativo.

Como explica Maria Sylvia Zanella Di Pietro, o exame dos motivos passou por uma evolução.

A primeira fase foi de um controle chamado mínimo, em que o Judiciário apenas constatava se o fato existiu ou não existiu; era um

\footnotetext{
${ }^{76}$ ARAÚJO, Edmir Netto de. Curso de Direito Administrativo. $1^{\text {a }}$ ed. Saraiva; SP: 2005. p. 451.
} 
controle da materialidade do fato. Depois passou-se a uma fase, que aqui no Brasil está um pouco atrasada, em que se admitiu o controle judicial da qualificação jurídica dos fatos (...). E mais um avanço ainda se deu em relação ao exame dos motivos, quando o Judiciário passou a examinar a adequação dos fatos aos fins que o ato deve produzir ${ }^{77}$.

Jessé Torres Pereira Junior assim sintetiza a doutrina dos motivos determinantes: "Se, nada obstante os espaços de discrição abertos pela norma, o administrador nomeia os motivos de suas escolhas, vincula-se a esses motivos, que passam a ser alvo do controle"78.

Em suma, declinados os motivos, o administrador está a eles adstrito. E o controle jurisdicional pode examinar esta adequação, seja quanto à real existência dos motivos, seja quanto à respectiva qualificação jurídica ou à adequação entre os fatos considerados e o fim perseguido pelo ato.

Em relação à teoria dos motivos determinantes, importa saber se a motivação dos atos administrativos é ou não obrigatória. Há divergência doutrinária a respeito. Alguns administrativistas sustentam que a motivação não é obrigatória senão quando se cuidar de ato vinculado, já que a obrigatoriedade de motivação seria incompatível com a discricionariedade.

Para outros, a motivação se faz necessária, justamente nos atos discricionários, já que nos atos vinculados bastaria o exame da lei com base na qual expedido o ato para que se aferisse o motivo que levou à sua expedição.

Edmir Netto de Araújo anota:

$\mathrm{Na}$ verdade, embora o princípio da motivação constitua moderna tendência dos países democráticos, a verdade é que as posições doutrinárias a respeito não são pacíficas.

Quanto aos atos vinculados, não há qualquer dúvida quanto a indispensabilidade da motivação, contemporânea ao ato, como requisito de validade, uma vez que a lei já traz todas as condições e formalidades prescritas para o ato, nada restando à escolha do agente público.

77 DI PIETRO, Maria Sylvia Zanella. Discricionariedade Administrativa e Controle Judicial da Administração. In Processo Civil e Interesse Público. SALLES, Carlos Alberto de (organizador). São Paulo: RT, 2003, pp. 186-187.

${ }^{78}$ PEREIRA JUNIOR, Jessé Torres. Controle Judicial da Administração Pública. $2^{\mathrm{a}}$ ed . Belo Horizonte: Fórum, 2006, p. 47. 
A questão vem à baila quanto aos atos discricionários: alguns autores entendem necessária a motivação de atos desta classe, elevando sua ausência ou explicitação tardia a fator de invalidade do ato. $\mathrm{Na}$ verdade, praticamente não há, na doutrina atual, quem tenha posição claramente contrária ao princípio da motivação obrigatória.

Apesar disso, no estágio atual de nosso ordenamento jurídico positivo (o que condiciona o estágio também atual da jurisprudência) entendemos que tal princípio não tenha sido ainda consagrado em toda sua plenitude, quer em razão da aplicabilidade da "teoria dos motivos determinantes", quer em razão da delimitação do exame, pelo Poder Judiciário, da matéria de fato referente ao mérito do ato administrativo.

Se a motivação for sempre obrigatória, sob pena de invalidade, e se aos motivos (determinantes) declarados a Administração se vincula, a própria existência do princípio da discricionariedade se torna duvidosa. A contrário da decisão jurisdicional em que a motivação é a regra, na decisão administrativa, o pronunciamento geralmente a dispensa, a não ser que norma legal a determine ${ }^{79}$.

Outra é a lição de Celso Antônio Bandeira de Mello:

Em se tratando de atos vinculados (nos quais, portanto, já está predefinida na lei, perante situação objetivamente identificável, a única providência qualificada como hábil e necessária para atendimento do interesse público), o que mais importa é haver ocorrido o motivo perante o qual o comportamento era obrigatório, passando para segundo plano a questão da motivação. Assim, se o ato não houver sido modificado, mas for possível demonstrar ulteriormente, de maneira indisputavelmente objetiva e para além de qualquer dúvida ou entredúvida, que o motivo exigente do ato preexistia, dever-se-á considerar sanado o vício do ato.

Entretanto, se se tratar de ato praticado no exercício de competência discricionária, salvo alguma hipótese excepcional, há de se entender que o ato não motivado está irresistivelmente maculado de vício e deve ser fulminado por inválido, já que a Administração poderia, ao depois, ante o risco de invalidação dele, inventar algum motivo, "fabricar" razões lógicas para justificá-lo e alegar que as tomou em consideração quando da prática do ato. Contudo, nos casos em que a lei não exija motivação, não se pode, consoante dito, descartar alguma hipótese excepcional em que seja possível à Administração demonstrar e de maneira absolutamente inquestionável que (a) o motivo extemporaneamente alegado preexistia; (b) que era idôneo para justificar o ato e (c) que tal motivo foi a razão determinante da prática do ato. Se estes fatores concorrerem há de se entender, igualmente, que o ato se convalida com a motivação ulterior ${ }^{80}$.

A Lei Federal sobre Processo Administrativo elege como um dos critérios básicos a serem observados pela Administração no processo administrativo a "indicação dos

\footnotetext{
${ }^{79}$ ARAÚJO, Edmir Netto de. Curso de Direito Administrativo. $1^{\text {a }}$ ed. São Paulo: Saraiva, 2005, pp. 69/70.

${ }^{80}$ BANDEIRA DE MELLO, Celso Antônio. Curso de Direito Administrativo. 22a ed. São Paulo: Malheiros, 2007, p. 385.
} 
pressupostos de fato e de direito que determinarem a decisão" (art. $1^{\circ}$, VII, Lei $\mathrm{n}^{\circ}$ 9.784/99).

Segundo parece, em alguns casos a motivação do ato discricionário é, mesmo, prescindível. É o que ocorre, por exemplo, quando o Chefe do Poder Executivo decide exonerar servidor ocupante de cargo de confiança. A simples perda da fides é o quanto basta para que o agente político opte por exonerar aquele servidor. Não é preciso declinar por que a confiança se quebrou. Em o declinando, porém, permite o administrador sejam esses motivos examinados, com fundamento na teoria dos motivos determinantes.

No geral, porém, ainda que se cuide de ato discricionário, a motivação é de fundamental importância - sobretudo porque a Administração tem um dever de transparência com relação ao administrado. 


\subsection{Os conceitos jurídicos indeterminados}

Dentro do estudo dos limites ao controle externo da Administração pelo Poder Judiciário, costuma-se fazer referência aos conceitos jurídicos indeterminados, ou, como prefere Afonso Rodrigues Queiró, conceitos plurissignificativos, “pois comportam um número limitado de significações igualmente possíveis, e não um número indefinido delas" $" 81$.

A grande questão que se apresenta é saber se os conceitos jurídicos indeterminados deixam para o administrador uma margem de interpretação ou de discricionariedade. A distinção tem relevo na medida em que, se se tratar de discricionariedade, a opção do agente público não poderá ser objeto de controle pelo Poder Judiciário. De outro lado, cuidando-se de margem de interpretação, poderá o juiz reputá-la como correta ou incorreta, sem que isso implique exame de mérito administrativo.

Maria Sylvia Zanella Di Pietro resume a discussão:

Quando se instaurou o Estado de Direito, a Administração passou a sujeitar-se à lei, mas uma lei que precisava ser interpretada. Reconheciase, tanto ao Judiciário como à Administração, o poder de interpretar a lei antes de sua aplicação. Aí é que surge, dentro da linha de Bernatzik, a idéia de que determinados conceitos utilizados pela lei, por serem vagos, são ininterpretáveis, gerando, para a Administração, a liberdade de fazer uma apreciação subjetiva diante dos fatos concretos, liberdade essa que corresponderia precisamente a um poder discricionário.

Não é necessário muito esforço para perceber que tal doutrina melhor se afeiçoa a um tipo de governo autoritário, já que reconhece maior poder para a Administração e menor para o Judiciário, ao qual se nega a possibilidade de apreciar aqueles atos emanados do poder discricionário.

Em linha diversa colocam-se os que, seguindo a doutrina de Tezner, entendem que todos os conceitos vagos são passíveis de interpretação, não implicando discricionariedade para a Administração. Essa doutrina quer limitar os poderes da Administração Pública, em benefício dos direitos dos cidadãos.

Em posição intermediária situam-se aqueles que reconhecem um poder discricionário para a Administração Pública em face dos conceitos indeterminados; todavia, essa discricionariedade não implica livre

${ }^{81}$ QUEIRÓ, Afonso Rodrigues. A Teoria do “Desvio de Poder” em Direito Administrativo. RDA 6/41, Rio de Janeiro, p. 56. 
apreciação. A autoridade administrativa deve utilizar todos os métodos possíveis de exegese para alcançar o interesse público que o legislador quis proteger ao conferir-lhe discricionariedade. Esta começa onde termina a interpretação ${ }^{82}$.

É fato que a interpretação faz parte tanto da atividade administrativa quanto da jurisdicional. $\mathrm{O}$ administrador, diante de uma norma e de um fato que se lhe apresentam, deve interpretá-los, cotejá-los e, enfim, verificar se há a necessária subsunção para que se produza o ato administrativo previsto. É esta a lição de Afonso Rodrigues Queiró:

Ora, entre a norma e a situação de fato, entre a norma e a realidade, interpõe-se o agente que, tendo-as ambas ante de si - a norma e sua enunciação dos fatos, e os fatos mesmos - está posto na necessidade, no dever, de tirar a conseqüência, isto é, de agir, de praticar este ou aquele ato.(...)

As condições de fato que a norma aponta são, pois, as condições de imputabilidade (...). Ante estas condições que vão sintetizadas no conceito geral de competência e designam o próprio conteúdo da atividade administrativa, tal como a ordem jurídica a delineia, o agente desenvolve primeiro uma atividade interpretativa $(. . .)^{83}$.

Também o juiz, no momento de proferir uma sentença, que fará lei entre as partes, que será o Direito para o caso concreto, interpreta tanto os fatos expostos no processo quanto as normas cuja aplicação se pretende, para então chegar a uma conclusão.

Em todas as normas há, pois, necessidade de interpretação. A discussão suscitada em relação aos conceitos jurídicos indeterminados surge, justamente, porque, em alguns casos, a lei não deixa, expressamente, margem de liberdade ao administrador - quando lhe permite, por exemplo, que decida autorizar ou não um determinado pedido segundo critérios de oportunidade e conveniência - nem tampouco usa um conceito, suficientemente claro, preciso, unívoco, de forma a que mediante a interpretação se chegue, sem sombra de dúvida, à solução correta - isto é, à única solução aceitável.

Vale dizer - diante de um determinado conceito constante da norma legal, o administrador se depara com atos que, definitivamente, nele não se enquadram; defronta-se com outros que, certamente, estão nele abrangidos. Pode acontecer, porém, que uma dada

\footnotetext{
${ }^{82}$ DI PIETRO, Maria Sylvia. Discricionariedade Administrativa na Constituição de 1988. $2^{\mathrm{a}}$ ed. São Paulo: Atlas, 2001,pp. 122/123.

${ }^{83}$ QUEIRÓ, Afonso Rodrigues. A Teoria do "Desvio de Poder" em Direito Administrativo. RDA 6/41, Rio de Janeiro, p. 56
} 
situação esteja em uma zona cinzenta, em uma posição intermédia. Neste caso, tanto é razoável concluir por sua pertinência ao conceito como por sua exclusão do âmbito de alcance daquele.

Sendo assim, ainda que o juiz, ao interpretar a norma, chegue a conclusão diversa daquela a que chegou o administrador, não poderá dizer que esta seja errada ou ilegal. E, tendo o administrador agido dentro da lei, seu ato não pode ser corrigido pelo Poder Judiciário.

Nesse caso, sustenta Celso Antonio Bandeira de Mello, há, sim, discricionariedade do administrador. Defende:

Deveras, qual o préstimo jurídico, ou seja, para que serve a noção de discricionariedade, senão para referir as situações em que a Administração desfruta de certa liberdade, por força da qual o Judiciário não pode ir além de certos limites, tendo de reconhecer que no interior deles a atuação administrativa é incensurável e que inexiste direito subjetivo de terceiro oponível procedentemente contra o comportamento administrativo adotado? A serventia jurídica, a utilidade, da noção de discricionariedade é única e exclusivamente a de rotular situações deste tipo. Ora, se tal "liberdade administrativa" e conseqüentes "limites" à correção judicial, tanto como "ausência de direito de terceiro" ante a Administração, resultam quer do uso legal de conceitos vagos, quer da possibilidade de opções de mérito ensejadas pela lei, quer da concorrência destes fatores, está-se a ver que a ressonância jurídica de ambos (conceitos indeterminados e opções de mérito legalmente previstas) é perfeitamente igual na esfera do direito. ${ }^{84}$

José dos Santos Carvalho Filho, de outro lado, distingue os conceitos, mas anota que

A razão pela qual têm sido confundidos os institutos decorre da circunstância de que ambos se enquadram na atividade não vinculada da Administração, uma vez que neles a norma não exibe padrões objetivo de atuação. Mas, enquanto o conceito jurídico indeterminado situa-se no plano de previsão da norma (antecedente), porque a lei já estabelece os efeitos que devem emanar do fato correspondente ao pressuposto nela contido, a discricionariedade aloja-se na estatuição da norma

${ }^{84}$ BANDEIRA DE MELLO, Celso Antônio. Discricionariedade e Controle Jurisdicional. $2^{\mathrm{a}}$ ed. São Paulo: Malheiros, 2003, p. 25. 
(consequiente), visto que o legislador deixa ao órgão administrativo o poder de ele mesmo configurar esses efeitos. ${ }^{85}$

Segundo Ramón Parada, o Tribunal Supremo espanhol não identifica a existência de discricionariedade nos conceitos jurídicos indeterminados. Explica o autor:

Do mesmo modo, o Tribunal Supremo tem declarado que nos conceitos jurídicos indeterminados - como é o caso evidente do justo preço expropriatório, cuja determinação chega a único preço (Sentença de 27 de junho de 1979) - pode distinguir-se no momento de sua aplicação ou do controle judicial entre um círculo de certeza positiva (hipóteses que claramente se ajustam ao conceito), um halo de incerteza (hipóteses de ajuste duvidoso) e um círculo de certeza negativa (hipóteses que claramente não se enquadram no conceito). Não obstante, e precisamente dentro desta zona de incerteza, surge de certo modo uma margem de apreciação, não de discricionariedade, que a Administração tem de resolver mediante a reunião de quantos elementos probatórios e de juízo sejam precisos para justificar a legalidade e o acerto da decisão (Sentenças de 22 de junho de 1982, 13 de julho de 1984 e 9 de dezembro de 1986) $)^{86}$.

No Direito Alemão, berço da doutrina dos conceitos jurídicos indeterminados, evita-se falar em discricionariedade com relação a essas zonas de incerteza, utilizando-se, em vez, a expressão espaço de apreciação.

\section{Relata Hartmut Maurer:}

Segundo a doutrina, desenvolvida por Bachof em 1955, do espaço de apreciação, é concedido à autoridade administrativa, pelo emprego de conceitos jurídicos indeterminados, um espaço de apreciação, isto é, um âmbito de valoração e decisão própria, não mais revisável judicialmente; os tribunais administrativos têm de aceitar as decisões situadas no interior desse âmbito, mas podem examinar se os limites desse âmbito são observados. $^{87}$

Todavia, os tribunais alemães têm uma interpretação muitíssimo restritiva, relativamente a esse espaço de apreciação, tendo o tribunal administrativo federal concluído que, ressalvadas poucas exceções, os “conceitos jurídicos indeterminados são

\footnotetext{
${ }^{85}$ CARVAlHO FILHO, José dos Santos. Manual de Direito Administrativo. $18^{\mathrm{a}}$ ed., Lumen Juris, Rio de Janeiro: 2007, p. 46.

${ }^{86}$ PARADA, Ramón. Derecho Administrativo. I Parte general. $9^{\text {a }}$ ed. Marcial Pons: Madrid, 1997 (tradução livre).

${ }^{87}$ MAURER, Hartmut. HECK, Luís Afonso (trad.). Direito Administrativo Geral.1 ${ }^{\text {a }}$ ed. Barueri: Manole, 2006, p. 154.
} 
completamente revisáveis judicialmente, a administração, portanto, não tem um espaço de apreciação" ${ }^{\# 8}$. Os casos em que os tribunais alemães têm reconhecido existir espaço de apreciação, segundo Hartmut Maurer, são os seguintes: a) decisões sobre exames (por exemplo, exame final no ensino secundário); b) decisões semelhantes ao exame, como questões envolvendo interesse pedagógico; c) apreciações jurídico-funcionalistas (verbi gratia, a apreciação do serviço de funcionário pelo seu superior); d) decisões de tipo valorativo por comissões livres de instrução, compostas por peritos e/ou representantes de interesses, aí incluída "a avaliação de locais para trigo por comissão de peritos independentes"; e) decisões sobre prognósticos e avaliações de risco, sobretudo no âmbito do Direito Ambiental e Direito Econômico; f) decisões referentes a fatores individuais, dados o conceito jurídico indeterminado, em especial, de tipo político-administrativo (ad exemplum, a "carência de serviço para a transferência de um funcionário"89).

No Brasil, como observa Gerson dos Santos Sicca,

A praxis forense tem mostrado aos juristas que as decisões judiciais têm variado conforme a questão posta em causa e até mesmo de acordo com a percepção eminentemente subjetiva do Magistrado. Em certos momentos, o controle atinge intensidade máxima, enquanto que em outros há uma severa limitação, sem que haja uma elucidação dogmática dos princípios que justificam a distinção de tratamento ${ }^{90}$.

\footnotetext{
${ }^{88}$ MAURER, Hartmut. HECK, Luís Afonso (trad.). Direito Administrativo Geral.1 ${ }^{\text {a }}$ ed. Barueri: Manole, 2006, p. 157.

${ }^{89}$ MAURER, Hartmut. HECK, Luís Afonso (trad.). Direito Administrativo Geral.1 ${ }^{a}$ ed. Barueri: Manole, 2006, pp. 158-163.

${ }^{90}$ SICCA, Gerson dos Santos. Conceitos Indeterminados no Direito Administrativo e Discricionariedade: Limites da Vinculação do Administrador no Estado Democrático de Direito.in Revista da AGU, Ano 3, nº5. Brasília/DF: dezembro de 2004, p. 18.
} 


\section{O SILÊNCIO ADMINISTRATIVO}

\subsection{Conceito de silêncio administrativo}

Impõe-se, de início, conceituar o silêncio administrativo. O silêncio é uma omissão, uma inércia da administração. Todavia, quando se faz referência à omissão administrativa, estão abrangidas outras espécies omissivas que não o silêncio. Vale dizer - a omissão é gênero de que o silêncio é espécie.

Costuma-se dizer que a Administração é omissa quanto à implementação de políticas públicas (por exemplo, quando não proporciona vagas suficientes para os alunos do ensino fundamental), quanto à fiscalização que lhe incumbe, no exercício do poder de polícia (como, verbi gratia, quando deixa de fiscalizar empresa que se revela grande poluidora), quanto à segurança pública dos cidadãos (nas hipóteses em que se deixa de policiar locais notoriamente perigosos) ou mesmo em relação à manutenção dos equipamentos públicos (quando, ad exemplum, se deixa de realizar o recapeamento de vias públicas, cujo mau estado de conservação pode redundar em acidentes, trazendo à baila a discussão acerca da responsabilidade do Estado por omissão).

Em nenhum dos exemplos mencionados, porém, há o chamado silêncio administrativo. Este se verifica quando, diante do pleito de um interessado, a Administração queda-se inerte.

$\mathrm{O}$ argentino Fernando E. Juan Lima diz que a inatividade administrativa tem três acepções, que vão da mais ampla (que abrange não apenas a inatividade da Administração, mas também do particular em suas relações com esta) à mais restrita (correspondente ao conceito de silêncio administrativo), passando por uma intermediária (que inclui apenas a inatividade formal da Administração, tanto em suas relações com os particulares, como em suas relações interorgânicas e interadministrativas).

Esclarece o autor: 
$\mathrm{Na}$ acepção mais restritiva, [o conceito] se refere somente à inatividade formal da Administração diante de uma petição de um ou mais particulares.

A este alcance, geralmente as leis de procedimento e os códigos processuais administrativos chamam silêncio administrativo ${ }^{91}$.

Muitos autores estrangeiros reservam a expressão silêncio administrativo para as hipóteses em que, quedando-se inerte a Administração diante de uma provocação do administrado, prevê a lei um sentido, positivo ou negativo, para esta inatividade. Vale dizer que a fórmula silêncio administrativo se aplica apenas aos casos em que a lei lhe confere uma determinada significação.

Nesse sentido, por exemplo, é a lição do espanhol Rafael Entrena Cuesta:

Em um sentido vulgar e etimológico existirá silêncio administrativo quando a Administração não responde às consultas, petições, reclamações, queixas, recursos, sugestões etc, que podem ser delineados. Sem embargo, nem a jurisprudência, nem a doutrina, nem o Direito positivo, assinalam tão amplo conteúdo ao instituto que começamos a examinar: em um sentido rigoroso, só se pode falar de silêncio administrativo quando o Ordenamento jurídico, ante a falta, dentro do prazo para tal estabelecido, de um pronunciamento que a Administração tem o dever de efetuar, presume - automaticamente ou após prévia denúncia da mora - a existência de um ato - geralmente negativo e excepcionalmente positivo - como meio para salvaguardar os direitos e interesses daqueles que formulam as petições, reclamações ou recursos não resolvidos, bem como a celeridade e eficácia administrativa ${ }^{92}$.

A doutrina pátria, de outro lado, tende a definir o silêncio administrativo como a inércia da Administração quando esta deveria manifestar-se.

Celso Antonio Bandeira de Melo explica que:

Se a Administração não se pronuncia quando deve fazê-lo, seja porque foi provocada por administrado que postula interesse próprio,

\footnotetext{
${ }^{91}$ JUAN LIMA, Fernando E. el silencio Administrativo: Problemas Actuales. Revista Eletrônica de Direito do Estado - ReDE nº7/2006, Instituto de Direito Público da Bahia, Salvador, p. 2. Disponível na Internet: http://www.direitodoestado.com.br . Acesso em 15 de outubro de 2007.

${ }^{92}$ CUESTA, Rafael Entrena. Curso de Derecho Administrativo. $5^{\mathrm{a}}$ ed. Madri: Editorial Tecnos, 1976, p. 516 (tradução livre).
} 
seja porque um órgão tem de pronunciar-se para fins de controle de ato de outro órgão, está-se perante o silêncio administrativo ${ }^{93}$.

José dos Santos Carvalho Filho, por sua vez, define o silêncio como a "omissão da Administração quando lhe incumbe manifestação de caráter comissivo"94.

Para o desenvolvimento deste trabalho, a definição de silêncio administrativo adotada será aquela dada pela doutrina brasileira - até porque muitos dos problemas referentes ao respectivo controle jurisdicional ocorrem, justamente, quando a lei se omite acerca das consequiências da falta de manifestação administrativa.

Portanto, no curso desta dissertação, quando se fizer referência a silêncio administrativo estar-se-á a denotar a inércia da Administração nas hipóteses em que lhe era imputado manifestar-se, em especial diante de pleito do administrado.

${ }^{93}$ BANDEIRA DE MELLO, Celso Antônio. Curso de Direito Adminitrativo. 22 $2^{\mathrm{a}}$ ed. São Paulo: Malheiros, 2007, p. 395.

${ }^{94}$ CARVALHO FILHO, José dos Santos. Manual de Direito Administrativo. $18^{\mathrm{a}}$ ed. Rio de Janeiro: Lumen Iuris, 2007, p. 94. 


\subsection{A natureza jurídica do silêncio}

Importa, para o estudo do controle do silêncio administrativo pelo Poder Judiciário que se pretende desenvolver nesta dissertação, analisar a natureza jurídica do silêncio administrativo, bem como suas conseqüências.

Discute-se, na doutrina, se o silêncio pode, sob certas condições, ser considerado ato administrativo ou se constitui mero fato jurídico administrativo.

Impõe-se, porém, a abertura de um parêntese - não se deve confundir o fato jurídico administrativo com a noção de fato administrativo. Como explica José dos Santos Carvalho Filho,

A idéia de fato administrativo não tem correlação com tal conceito [de fato jurídico], pois que não leva em consideração a produção de efeitos jurídicos, mas, ao revés, tem o sentido de atividade material no exercício da função administrativa, que visa a efeitos de ordem prática para a Administração. Exemplos de fatos administrativos são a apreensão de mercadorias, a dispersão de manifestantes, a desapropriação de bens privados, a requisição de serviços ou bens privados etc. Enfim, a noção indica tudo aquilo que retrata alteração dinâmica na Administração, um movimento na ação administrativa. Significa dizer que a noção de fato administrativo é mais ampla que a de fato jurídico, uma vez que, além deste, engloba também os fatos simples, ou seja, aqueles que não repercutem na esfera de direitos, mas estampam evento material ocorrido no seio da Administração ${ }^{95}$.

A questão que ora se propõe diz respeito à natureza jurídica do silêncio administrativo. Para respondê-la, é preciso ter presente que o ato administrativo é espécie do gênero ato jurídico.

Mais uma vez na lição de José dos Santos Carvalho Filho,

Os elementos estruturais do ato jurídico - o sujeito, o objeto, a forma e a própria vontade - garantem sua presença também no ato administrativo. Ocorre que neste o sujeito e o objeto têm qualificações

${ }^{95}$ CARVAlHO FILHO, José dos Santos. Manual de Direito Administrativo. $18^{\mathrm{a}}$ ed. Rio de Janeiro: Lúmen Juris, 2007, p. 89. 
especiais: o sujeito é sempre um agente investido de prerrogativas públicas, e o objeto há de estar preordenado a determinado fim de interesse público. Mas no fundo será ele um instrumento da vontade para a produção dos mesmos efeitos do ato jurídico. Temos, assim, uma relação de gênero e espécie. Os atos jurídicos são o gênero do qual os atos administrativos são a espécie, o que denota em que ambos são idênticos os elementos estruturais ${ }^{96}$.

Assim, é imprescindível conceituar o ato jurídico, verificando suas notas características, distinguindo-o do fato jurídico.

De início, cumpre ressaltar que o Código Civil de 2002 preferiu a expressão negócio jurídico a ato jurídico. Utilizando-se nomenclatura atual, portanto, é mais adequado dizer que o ato administrativo é espécie de negócio jurídico, impondo-se estudar as características deste.

Sílvio Rodrigues ensina:

Assim, parece melhor classificar os fatos jurídicos da seguinte maneira: de início devem ser separados os fatos jurídicos em sentido estrito, isto é, fatos que não envolvem qualquer ato humano por advirem de forças alheias ao homem, dos atos humanos, a que se poderia dar o nome de atos jurídicos, ou atos jurígenos, como fazem alguns escritores, para lembrar que se trata de atos capazes de criar relações na órbita do direito. Estes podem ser ilícitos, se desconformes com a lei, ou lícitos, se com ela se afinarem. Dentre os atos lícitos dever-se-iam separar os inspirados num propósito negocial, ou seja, na deliberação de alcançar um efeito jurídico - e teríamos então o negócio jurídico, dos atos meramente lícitos, em que o efeito jurídico alcançado não é perseguido pelo agente ${ }^{97}$.

O alagoano Marcos Bernardes de Mello apresenta a seguinte noção de ato jurídico (em seu livro escrito sob a égide do Código Civil de 1916):

Denomina-se ato jurídico o fato jurídico cujo suporte fáctico tenha como cerne uma exteriorização consciente de vontade, dirigida a obter um resultado juridicamente protegido ou não-proibido e possível ${ }^{98}$.

\footnotetext{
${ }^{96}$ CARVALHO FILHO, José dos Santos. Manual de Direito Administrativo. $18^{\mathrm{a}}$ ed. Rio de Janeiro: Lúmen Juris, 2007, p. 91.

${ }^{97}$ RODRIGUES, Sílvio. Direito Civil - Parte Geral. Vol. 1. 34 ed. São Paulo: Saraiva, 2007, p. 158.

${ }^{98}$ DE MELLO, Marcos Bernardes. Teoria do Fato Jurídico (Plano da Existência). $7^{\mathrm{a}}$ ed. São Paulo: Saraiva, 1995 , p. 117.
} 
Como se percebe, a primeira característica apresentada pelo autor como caracterizadora do ato jurídico é a exteriorização da vontade, "mediante simples manifestação ou declaração, conforme a espécie, que constitua uma conduta juridicamente relevante e, por isso, prevista como suporte fáctico de norma jurídica"99.

José Martins Rodrigues anota:

O elemento fundamental dos atos jurídicos, de que o contrato é a espécie mais comum, vem a ser a declaração de vontade, ou seja a manifestação do consentimento quanto à relação de direito a constituir,modificar ou extinguir ${ }^{100}$.

Sílvio Rodrigues escreve:

Entre os elementos essenciais do negócio jurídico figura, em primeiro lugar, a vontade humana, pois, vimos, o negócio jurídico é fundamentalmente um ato de vontade. Todavia, como a vontade é um elemento de caráter subjetivo, ela se revela através da declaração, que, deste modo, constitui, por sua vez, elemento essencial ${ }^{101}$.

Resta saber se a omissão pode caracterizar manifestação de vontade.

Pode-se dar alguma significação ao silêncio? Como pontificou Serpa Lopes,

As opiniões dividem-se: uns negam ao silêncio qualquer valor como afirmação de vontade; outros, admitem-no, desde que concorram determinadas circunstâncias.

Contradizem-se aforismos e provérbios.

Enquanto se afirma que "quem cala consente", alega-se, de outra parte, que "quem silencia nada diz".

Saindo do terreno da consciência popular para o jurídico, aparecem, desde logo, duas regras contrárias: "qui tacet no utique fatetur sed tamem verum est non negare" (L. 142, D. de R.J.); "qui tacet consentire videtur" (I. 43, D. de Reg. Jur. In Sexto).

O caso de "silêncio", que importa investigar, é o silêncio oriundo de um defeito total de expressão, quando não existem palavras nem sinais de expressão, permanecendo purificado em sua própria essência de negatividade e abstenção.

O indivíduo nada disse. Nem por ele os fatos, como órgão e expressão de suas decisões.

\footnotetext{
${ }^{99}$ DE MELLO, Marcos Bernardes. Teoria do Fato Jurídico (Plano da Existência). $7^{\mathrm{a}}$ ed. São Paulo: Saraiva, 1995, p. 117.

${ }^{100}$ RODRIGUES, José Martins. Efeitos Jurídicos do Silêncio. Fortaleza: Livraria Humberto, 1034, p. 70.

${ }^{101}$ P.171.
} 
Envolto em trevas, o silêncio é como um mistério, um enigma à sociedade e à lei ${ }^{102}$.

O autor opina:

Depois de termos analisado o valor do silêncio, no tríplice ponto de vista da psicologia, sociologia e do Direito (...) não trepidamos em asseverar que o "silêncio" constitui um elemento capaz de aquisição, modificação e extinção de direitos, como o é, igualmente, para a formação dos contratos ${ }^{103}$.

E, concluindo, define o silêncio como:

uma manifestação de vontade, por meio de um comportamento negativo, deduzida de circunstâncias concludentes, caracterizadas pelo dever e possibilidade de falar quanto ao silente e pela convicção de outra parte, indicando uma inequívoca direção da vontade incompatível com a expressão de uma vontade oposta ${ }^{104}$.

Não se confundem, porém, a manifestação e a declaração de vontade; enquanto a primeira se caracteriza por um mero comportamento, a segunda é uma manifestação qualificada. Mais uma vez na lição de Marcos Bernardes de Mello,

Disto resulta evidente que declaração e manifestação são modos (= formas) de exteriorização da vontade e, por isso, constituem elementos complementares do suporte fáctico dos atos jurídicos. Embora não sejam o próprio cerne, são dados que completam o núcleo, donde a sua presença constituir elemento essencial à concreção do suporte fáctico suficiente à incidência da norma jurídica, portanto, à própria existência do ato jurídico. Daí decorre que, se a norma jurídica exige, como elemento do suporte fáctico de certo ato jurídico, que a vontade seja exteriorizada mediante declaração, a exteriorização por outra forma não bastará a que se possa considerá-lo existente; quer dizer: a falta da declaração onde ela é exigida acarreta a inexistência do ato jurídico, não somente sua nulidade ou ineficácia ${ }^{105}$.

\footnotetext{
${ }^{102}$ LOPES, Miguel Maria de Serpa. O Silêncio como Manifestação da Vontade. Rio de Janeiro: A. Coelho Branco Filho, 1935, p. 6.

${ }^{103}$ LOPES, Miguel Maria de Serpa. O Silêncio como Manifestação da Vontade. Rio de Janeiro: A. Coelho Branco Filho, 1935, p. 161

${ }^{104}$ LOPES, Miguel Maria de Serpa. O Silêncio como Manifestação da Vontade. Rio de Janeiro: A. Coelho Branco Filho, 1935,p. 162.

${ }^{105}$ DE MELLO, Marcos Bernardes. Teoria do Fato Jurídico (Plano da Existência). $7^{\mathrm{a}}$ ed. São Paulo: Saraiva, 1995, p. 118.
} 
Pablo Stolze Gagliano e Rodolfo Pamplona Filho mencionam que, não obstante haja quem negue qualquer valor ao silêncio, há diversas situações em que a abstenção do agente ganha juridicidade; mencionam, por exemplo, o artigo 539 do Código Civil, segundo o qual, na doação pura, o silêncio no prazo fixado significa aceitação, e o artigo 659 do Código Civil, referente à profissão de mandatário ${ }^{106}$.

O Código Civil de 2002, aliás, trouxe disposições expressas acerca do silêncio, como por exemplo:

Art. 111. O silêncio importa anuência, quando as circunstâncias ou os usos o autorizarem, e não for necessária a declaração de vontade expressa.

Art. 147. Nos negócios jurídicos bilaterais, o silêncio intencional de uma das partes a respeito de fato ou qualidade que a outra parte haja ignorado, constitui omissão dolosa, provando-se que sem ela o negócio não teria sido celebrado.

No âmbito administrativo, os doutrinadores têm se referido à exigência da exteriorização de vontade para que se possa cogitar de um ato administrativo. José Cretella Júnior, porém, entende que o elemento não pode simplesmente ser transposto do Direito Civil para o Direito Administrativo, porque há diferenças substanciais entre um e outro campo. Escreve o autor:

Sendo o negócio jurídico informado sempre pela declaração de vontade, difícil é levar essa contribuição do direito civil para o campo do direito administrativo, porque os institutos desta disciplina são informados pelo elemento finalidade.

Qualquer que seja a tendência pessoal do agente público, a vontade humana é abrangida e superada pela idéia de finalidade, motora única do interesse público. No direito privado, predomina a vontade; no direito administrativo, prevalece a idéia de finalidade. Mesmo ao contratar com os particulares, a Administração tem de agir por interesse público, ficando a vontade do agente superada pelo fim, o qual vincula $o$ administrador.

Se a vontade é irrelevante no direito administrativo, inexiste aqui a respectiva declaração, pois não se pode extravasar o que não

\footnotetext{
${ }^{106}$ GAGLIANO, Pablo Stolze, e PAMPLONA FILHO, Rodolfo. Novo Curso de Direito Civil. $8^{\text {a }}$ ed. São Paulo: Saraiva: 2006, p. 323.
} 
existe. Declaração do inexistente é declaração vazia e, pois, inócua, inoperante, ineficaz. Ora, o elemento declaração de vontade está presente em todas as definições do negócio jurídico $^{107}$.

De uma maneira geral, porém, a doutrina administrativista tem reconhecido na manifestação de vontade requisito de existência do ato administrativo. Nem todos, porém, aceitam que a simples manifestação seja apta a caracterizá-lo.

Maria Sylvia Zanella Di Pietro escreve que o ato administrativo

constitui declaração do Estado ou de quem lhe faça as vezes; é preferível falar em declaração do que em manifestação, porque aquela compreende sempre uma exteriorização do pensamento, enquanto a manifestação pode não ser exteriorizada; o próprio silêncio pode significar manifestação de vontade e produzir efeito jurídico, sem que corresponda a um ato administrativo, ${ }^{108}$

Para a autora, portanto, não basta a manifestação de vontade para a existência de um ato administrativo; é preciso que haja uma declaração de vontade. A exigência foi incluída no seu conceito de ato administrativo, como "a declaração de vontade do Estado ou de quem o represente, que produz efeitos jurídicos imediatos, com a observância da lei, sob regime jurídico de Direito Público e sujeita a controle pelo Poder Judiciário"109.

Segundo Hely Lopes Meirelles,

o silêncio não é ato administrativo; é conduta omissiva da Administração que, quando ofende direito individual ou coletivo dos administrados ou de seus servidores, sujeita-se a correção judicial e a reparação decorrente de sua inércia. ${ }^{110}$

Leciona Celso Antonio Bandeira de Mello:

Na verdade, o silêncio não é ato jurídico. Por isto, evidentemente, não pode ser ato administrativo. Este é uma declaração jurídica. Quem se

${ }^{107}$ CRETELla JÚNIOR, José. Dos Atos Administrativos Especiais. 2a ed. Rio de Janeiro: Forense, 1995, p. 51.

${ }^{108}$ DI PIETRO, Maria Sylvia Zanella. Direito Administrativo. $19^{\text {a }}$ ed. São Paulo: Atlas, 2006, p. 205.

${ }^{109}$ DI PIETRO, Maria Sylvia Zanella. Direito Administrativo. $19^{\mathrm{a}}$ ed. São Paulo: Atlas, 2006, p. 206.

${ }^{110}$ MEIRELLES, Hely Lopes. Direito Administrativo Brasileiro. 26a ed., atualizada por Eurico Andrade Azevedo, Délcio Balestero Aleixo e José Emmanuel Burle Filho. São Paulo: Malheiros, 2001, p. 106. 
absteve de declarar, pois, silenciou, não declarou nada e por isto não praticou ato administrativo algum. Tal omissão é um "fato jurídico" e, in casu, um "fato jurídico administrativo". Nada importa que a lei haja atribuído determinado efeito ao silêncio, como imputação legal, e não de algum presumido ato, razão por que é de se rejeitar a posição dos que consideram ter aí existido "ato tácito"

Na doutrina estrangeira, é comum encontrar opiniões em contrário. O espanhol Rafael Entrena Cuesta, por exemplo, escreve:

Dissemos que na hipótese de silêncio administrativo, o Ordenamento jurídico presume a existência de um ato. Encontramo-nos, pois: $1^{\circ}$ Diante de um verdadeiro ato administrativo, que possui "a mesma transcendência jurídica..., que os atos expressos mediante os quais normalmente se pronuncia a Administração (S. de 2 de dezembro de 1959)". $2^{\circ}$ Mas ato presumido. Pelo que, sobre a controvérsia dos atos tácitos, está fechada a porta a todo trabalho hermenêutico acerca do valor que se deva atribuir ao silêncio da Administração. Dito valor será sempre o que disponha do Direito positivo (Sic. S. de 25 de janeiro de $1968)^{112}$.

No Direito alemão a doutrina costumava reconhecer a ocorrência do chamado ato fictício quando a lei atribuísse à inércia administrativa por um dado período de tempo uma conseqüência específica. A solução, porém, conta com a ferrenha oposição de Hartmut Maurer. Para o autor, o mero silêncio não pode ser concebido como ato administrativo. Segundo escreve,

$\mathrm{O}$ ato administrativo fictício, em época recente, foi empregado mais intensificadamente pelo dador de leis por fundamentos de aceleração do procedimento e encontrou, em conformidade com isso, na literatura, observância mais intensificada. Não se trata, na realidade, de um ato administrativo; mas em virtude de lei a situação jurídica deve ser observada como se um ato administrativo tivesse sido promulgado. A ficção legal não se limita a atos administrativos, mas estende-se também a outros atos jurídicos, por exemplo, ao acordo entre os municípios e à aprovação das autoridades administrativas superiores, segundo o $\$ 36$ II do código de construção $(. . .)^{113}$.

\footnotetext{
${ }^{111}$ BANDEIRA DE MELlo, Celso Antônio. Curso de Direito Administrativo. 22a ed. São Paulo: Malheiros, 2007, p. 396.

${ }^{112}$ CUESTA, Rafael Entrena. Curso de Derecho Administrativo. $5^{\mathrm{a}}$ ed. Madri: Editorial Tecnos, 1976, p. 517 (tradução livre).

${ }^{113}$ MAURER, Hartmut. HECK, Luís Afonso (trad.). Direito Administrativo Geral.1 ${ }^{\mathrm{a}}$ ed. Barueri: Manole, 2006, p. 274.
} 
Não parece inadequado admitir que o silêncio administrativo possa caracterizar um ato administrativo, se a lei, de antemão, previr que o escoamento de determinado prazo implica o acolhimento ou a denegação da pretensão do administrado. Ora, em tais casos as consequiências do decurso do prazo sem manifestação serão, rigorosamente, idênticas àquelas que ocorreriam se a Administração apreciasse expressamente o pleito. Se o silêncio tem caráter negativo, isto é, denegatório do pleito do administrado, este poderá ingressar em juízo, exatamente como faria, se seu pedido houvesse sido recusado pela Administração. De outro lado, em se cuidando de silêncio positivo, concessório da pretensão do interessado, este poderá exercitar o direito daí decorrente, tal qual faria se o deferimento houvesse sido expresso.

A objeção referente à falta de declaração não parece suficiente para que se afaste, sem mais, o caráter de ato administrativo do silêncio positivo ou negativo. Isso porque, nesses casos, a declaração é presumida e decorre da própria lei. Vale dizer: a lei determina que, na omissão da administração, entende-se praticado determinado ato - concessivo ou denegatório.

De qualquer modo, o importante é deixar evidenciado que, quando a lei determina o significado do silêncio administrativo, as consequiências desse silêncio são as mesmas da emissão do ato omitido, que se presumiu praticado.

Edmir Netto de Araújo analisa a questão:

Muitos são os exemplos de atitudes omissivas que determinam repercussões jurídicas circunstanciais: no Direito Civil, o silêncio nas relações patrimoniais e até na celebração do casamento, pode produzir efeitos jurídicos pelo assentimento tácito; no Direito Penal, a omissão de socorro está tipificada criminalmente; no Direito Constitucional, temos a responsabilidade patrimonial do Poder Público (art. 37, $\S 6^{\circ}$, Constituição Federal) por omissões de seus agentes; no Direito Administrativo, a omissão administrativa quando há prazo determinado para a prática de um ato ou comportamento, significa decisão implícita de rejeição e pode até ser defendido eventual direito líquido e certo do prejudicado pela omissão através de mandado de segurança; no Direito Processual temos os efeitos da confissão e da revelia. Enfim, pode o Judiciário até mesmo editar sentença cujos efeitos se equiparam aos da declaração de vontade que deixou de emitir o agente, como no caso do suprimento de consentimento ou de outorga uxória ${ }^{114}$.

\footnotetext{
${ }^{114}$ ARAÚJO, Edmir Netto de. Do Negócio Jurídico Administrativo. 1ª ed. São Paulo: RT, 1992, p. 34.
} 


\subsection{A teoria do silêncio administrativo - as conseqüências do silêncio da Administração}

No estudo da teoria dos atos administrativos, tem-se mostrado bastante controversa a questão da inação administrativa, na chamada teoria do silêncio administrativo.

Um famoso adágio popular diz que "quem cala consente". A origem da referida máxima remonta ao Direito Romano (“Qui tacet consentire videtur").

Mas nem sempre o silêncio indica consentimento, mesmo no âmbito do Direito Privado. Como escreveu Santiago Dantas,

O silêncio pode significar tudo, pode significar concordância e pode significar discordância, pois que a sua significação se completa graças aos atos jurídicos com os quais se colocam em relação. Daí compreenderem que a máxima tão divulgada há algum tempo - qui tacet consentire videtur - traduzida pelos antigos no nosso refrão - quem cala consente, não tem sentido jurídico, pois que o silêncio tanto pode significar o consentimento, como pode significar o não consentimento, tudo dependendo da lei, do costume ou da convenção em relação à qual devemos interpretar aquele silêncio.

Aproxima-se alguém de outrem e lhe diz que mandou carta a certo comissário na praça de Santos, ordenando que comprasse mil sacas de algodão e ele nada respondeu, nem comprou. Será ele responsável ou não para com aquele alguém? O problema é o seguinte: que convenção existia entre o comitente e seu comissário? Responde-se: nenhuma. Perguntarão então: qual era a praxe anterior. Se o costume era que se comprasse sem responder e só responder para dizer que não comprava, então não há dúvida alguma de que ele está em falta para com o comitente; se o costume, porém, era de que ele respondesse antes de comprar, ele não tem nenhuma responsabilidade.

E se não havia costume entre ambos, então se deve indagar do costume, lei ou convenção esclarecer o sentido deste silêncio, então, o que se tem de concluir, é que o silêncio é irrelevante e que não se pode dar-lhe nenhuma interpretação ${ }^{115}$.

Isto é, o silêncio não tem, por si só, uma significação, necessitando ser integrado pela lei, pelos costumes ou por convenções.

115 DANTAS, San Tiago. Programa de Direito Civil - Parte Geral.3 ${ }^{a}$ tiragem. Rio de Janeiro: Editora Rio, 1979, pp. 260/261. 
Todavia, como sói acontecer, a solução para o ente público é diversa da aplicável ao particular. Ao que parece, não se pode, em princípio, admitir que o silêncio da Administração seja integrado senão pela lei - exceção feita à proteção da boa-fé do administrado, em situações específicas.

Isso porque o princípio da legalidade, para a Administração, opera às avessas: enquanto ao particular é permitido fazer tudo o que a lei não proscreva, à Administração impõe pautar sua conduta rigorosamente pela lei, só atuando conforme esta lhe permitir. Conforme escreveu Hely Lopes Meirelles:

Enquanto na administração particular é lícito fazer tudo o que a lei não proíbe, na Administração Pública só é permitido fazer o que a lei autoriza. A lei para o particular significa "pode fazer assim"; para o administrador público significa "deve fazer assim"116.

Portanto, a regra de valoração do silêncio da Administração deve ser pautada, necessariamente, pelo princípio da legalidade. Vale dizer - as conseqüências do silêncio da Administração devem ser estudadas de acordo com as regras de Direito Administrativo, que não se confundem com as normas de Direito Privado.

A propósito, anota René Chapus: "Para o direito administrativo, a regra é: quem cala, recusa" ${ }^{\prime 17}$.

Verificado o silêncio administrativo, pode haver duas hipóteses: ou há lei regulando tal inércia e prevendo-lhe a conseqüência, ou inexiste previsão legal.

Edmir Netto de Araújo escreve:

Atos jurídicos, focalizados quer em sentido lato, quer em sentidos específicos de atos não negociais e negócios jurídicos, apresentam em comum a ocorrência de manifestação da vontade humana ou de conduta conforme essa vontade, desencadeando efeitos jurídicos prescritos pelo ordenamento, em um caso, ou admitidos pela ordem jurídica, em outro.

\footnotetext{
${ }^{116}$ MEIRELLES, Hely Lopes. Direito Administrativo Brasileiro. 26 ${ }^{\mathrm{a}}$ ed., atualizada por Eurico Andrade Azevedo, Délcio Balestero Aleixo e José Emmanuel Burle Filho. São Paulo: Malheiros, 2001, p. 82.

${ }^{117}$ CHAPUS, René. Droit administratif général. Tome 1. 15 a ed. Paris: Montchrestien, 2001, p. 506 (tradução livre).
} 
Indaga-se, então: é só através de comportamento ativo do homem que sua vontade é declarada? Não há certos casos, seja o comportamento devido ou vedado, em que o silêncio ou a inação representam verdadeiras declarações de vontade?

A teoria do silêncio é capítulo controvertido e ainda incerto da ciência jurídica, seja no âmbito do direito privado, seja no campo do direito público; seu valor jurídico varia conforme o ângulo do Direito que é estudado, caracterizando-se pela inação, pela ausência de exteriorização; mas mesmo assim, como ato negativo ou omissivo, pode exprimir vontade, de consentimento ou de rejeição-negação, e gerar, de per si, consequiências jurídicas.

\section{(...)}

$\mathrm{Na}$ área do direito privado, a ausência de manifestação geralmente significa assentimento tácito, ao passo que no âmbito do direito público, se o direito positivo não atribuir expressamente consequiências à omissão administrativa em certa situação, a inércia do agente ou do órgão público, se há prazo assinalado para a ação, significa denegação da pretensão do interessado.

O que parece claro é que o fato jurídico voluntário consiste numa conduta humana; ato positivo ou negativo do homem, gerando efeitos jurídicos, e, se não vamos tão longe a ponto de considerar ato e omissão como sinônimos, a verdade é que, sob o ângulo da vontade do interessado sobre o resultado, ambos podem produzir consequiências congêneres, até mesmo configurar a vontade negocial ${ }^{118}$.

E conclui:

Por isso, cada caso concreto deve ser detidamente estudado: a omissão só produz efeitos jurídicos, na ausência de disciplina legal expressa, quando, pelas circunstâncias, a atitude de quem silencia induz a outra parte, como induziria a qualquer pessoa, e, condições normais, à crença legítima de haver o silente revelado, desse modo, uma vontade seguramente identificada ${ }^{119}$.

Em suma, defende o doutrinador que, não havendo previsão legal de conseqüência para a inércia administrativa, só se pode extrair dela algum significado em homenagem à proteção da confiança legítima - isto é, se pelas circunstâncias em que se deu o silêncio o administrado creu, legitimamente, ter havido assentimento ou denegação por parte da Administração.

Se houver lei prevendo a conseqüência do silêncio, este pode implicar a rejeição ou o acolhimento da pretensão do particular. Segundo Celso Antônio Bandeira de Mello, estando previsto o acolhimento da pretensão, o administrado está atendido; se o efeito do

${ }_{118}$ ARAÚJO, Edmir Netto de. Do Negócio Jurídico Administrativo. $1^{\text {a }}$ ed. São Paulo: RT, 1992, p. 33.

${ }^{119}$ ARAÚJO, Edmir Netto de. Curso de Direito Administrativo. $1^{\text {a }}$ ed. São Paulo: Saraiva, 2005. p. 430 
decurso do prazo sem manifestação era denegatório, este poderá ingressar em juízo com vistas a obter a satisfação de seu direito. O pedido veiculado na ação, porém, distingue-se, conforme se trate de ato vinculado ou discricionário:

[o administrado] poderá demandar judicialmente que a Administração se pronuncie, se o ato omitido era de conteúdo discricionário, pois faz jus a uma decisão motivada; se, pelo contrário, o ato era de conteúdo vinculado e o administrado fazia jus a ele, demandará que o juiz supra a omissão administrativa e lhe defira o postulado ${ }^{120}$.

Continua o autor ensinando que, nas hipóteses em que a lei nada dispuser a respeito, a solução será semelhante - cuidando-se o ato omitido de ato vinculado, poderá o administrado pedir ao juiz o suprimento da omissão. Tratando-se de ato discricionário, pedirá ao juiz que anote prazo para que a Administração se manifeste, sob pena de multa diária.

Celso Antonio Bandeira de Mello ainda sustenta que, à míngua de lei específica a respeito, o prazo para a Administração manifestar-se deva ser o mesmo previsto pela Lei de Processo Administrativo Federal, isto é, trinta dias ${ }^{121}$.

A discussão acerca dos limites ao controle jurisdicional da inação administrativa será melhor estudada no terceiro capítulo deste trabalho.

\footnotetext{
${ }^{120}$ BANDEIRA DE MELLO, Celso Antônio. Curso de Direito Administrativo. $22^{\mathrm{a}}$ ed. São Paulo: Malheiros, 2007, p. 398. Até a décima sexta edição do livro, o autor defendia quando defendia que o lapso seria de cento e vinte dias, a exemplo do prazo decadencial para impetração de mandado de segurança (na $11^{\mathrm{a}}$ edição, $\mathrm{p}$. 295).

${ }^{121}$ BANDEIRA DE MELLO, Celso Antônio. $22^{\mathrm{a}}$ ed. Curso de Direito Administrativo. São Paulo: Malheiros, 2007, p. 398
} 


\subsection{O silêncio administrativo no Direito estrangeiro}

\subsubsection{O silêncio administrativo no Direito italiano}

Ao contrário do que acontece no Brasil, onde o tema do silêncio administrativo tem merecido pouca atenção, na Itália o assunto tem destaque na jurisprudência e na doutrina, chegando a ocupar capítulos inteiros de manuais de Direito Administrativo. Mostra-se bastante interessante o exame da legislação italiana, que trata, expressamente, do silêncio da Administração Pública e que, aliás, teve recentíssimas alterações.

A doutrina italiana costuma situar o estudo do silêncio administrativo no âmbito das formas de exteriorização da vontade da Administração. O silêncio assume valor de manifestação de vontade quando tenha um valor legal tipificado ou quando reste configurado um ato tácito. A legislação em algumas situações atribui ao silêncio o valor de acolhimento de uma pretensão; em outras vezes, equipara-o à recusa de um pleito. Como ensina Ugo Di Benedetto, em se tratando de exceção ao princípio pelo qual a Administração é que deve determinar a ordenação dos interesses confiados a seus cuidados, tais normas devem ser interpretadas restritivamente, vedada a interpretação analógica ${ }^{122}$.

Segundo entendem os italianos, nem sempre o silêncio da Administração é ilegítimo. A jurisprudência esclareceu que a inércia da Administração Pública torna-se juridicamente relevante apenas quando houver uma obrigação jurídica de proceder - o que é pressuposto nas hipóteses de atividade vinculada. Já nas atividades discricionárias, tal obrigatoriedade pode advir de normas, legais ou regulamentares, bem como de uma autolimitação imposta pela Administração ela mesma. O Conselho de Estado italiano manifestou que não existe a obrigação de manifestação em instância de reexame, de anulação ou de revogação de ofício de um procedimento não mais impugnável pelo particular (Cons. Stato, Sez. V, n. 89/1995). Sobre o assunto, decidiu o Conselho de Estado italiano:

${ }^{122}$ DI BENEDETTO, Ugo. Diritto Amministrativo. $3^{\text {a }}$ ed. Santarcangeli di Romagna: Maggiole, 2007, p. 533. 
A jurisprudência, partindo do princípio geral da obrigatoriedade da ação administrativa, e integrando-o com as regras de razoabilidade e boa-fé, tende a ampliar o âmbito das situações em quem há obrigação de decidir, além daqueles expressamente previstos pela lei. Afirma-se que existe a obrigação de decidir, além dos casos previstos na lei, nas hipóteses particulares nas quais as razões de justiça e eqüidade imponham a adoção de uma decisão (Cons. Stato, Sez. V, n. 250).

A jurisprudência e a doutrina italiana conhecem diversos tipos de silêncio. De início, cumpre distinguir as hipóteses de silêncio-significativo, quando a lei atribui determinada conseqüência ao silêncio. Incluem-se, nesta categoria, o silêncio denegatório (silenzio-diniego), que provoca a rejeição do pedido do interessado, e o silêncioassentimento (silenzio-assenso), que tem caráter positivo. Quando a lei não atribui nenhuma conseqüência ao silêncio da Administração, fala-se em silêncio-inadimplemento (silenzio-inadimpimento) ou silêncio-recusa (silenzio-rifiuto) - o que ocorre, segundo alguns autores, quando há inércia da Administração diante de uma atividade discricionária. Fala-se, ainda, em silêncio-rejeição (silenzio-rigetto) ou silêncio sobre recurso hierárquico (silenzio della pubblica amministrazione in ordine al ricorso amministrativo), que se distingue das hipóteses de silêncio puro porque pressupõe a existência de um primeiro ato administrativo, contra o qual se insurge o administrado.

Interessante observar, ainda, que, contrariamente ao que ocorre na maioria dos países que têm um tratamento específico para a matéria do silêncio da Administração, na Itália o silêncio equivale, em regra, ao acolhimento da pretensão. É o que explica Elio Casetta:

O nosso ordenamento conhece várias formas de silêncio: silênciorejeição, silêncio significativo, silêncio inadimplemento, silêncio devolutivo. É importante relevar que, ao menos no ordenamento, a regra, a ser aplicada salvo disposição contrária quando a Administração permanece inerte, é a do silêncio-assentimento, que é uma das tipologias do silêncio significativo.

Nas hipóteses de silêncio-significativo, o ordenamento atribui ao decurso do prazo a produção de um efeito equivalente ao da emanação de um provimento favorável (silêncio-assentimento) ou desfavorável (silêncio denegatório) ao pedido de um particular titular de uma pretensão ${ }^{123}$.

${ }^{123}$ CASETTA, Elio. Compendio di Diritto Amministrativo. 6a ed. Milano: Giuffrè Editore, 2006, p. 319 (tradução livre). 
Ocorre um silêncio-significativo, pois, quando a lei atribui ao silêncio um valor, positivo ou negativo. Cuida-se das hipóteses de silêncio-denegatório e silêncio assentimento. Diz-se que, nestes casos, há um valor legal típico.

As hipóteses de silêncio-denegatório são excepcionais, estando previstas expressamente em lei. Cuida-se de hipóteses e matérias nas quais o próprio legislador estabelece, explica Italo Franco, que "na falta de resposta do órgão competente, o pedido deve reputar-se rejeitado, com as conseqüências que advêm de uma decisão desfavorável" ${ }^{\prime 24}$.

Já o silêncio-assentimento, regra no ordenamento italiano, ocorre quando a inércia da Administração implica o acolhimento da pretensão do interessado. Explica Ugo Di Benedetto :

(...) quando o ordenamento toma diretamente em consideração o comportamento silencioso para atribuir a ele uma qualificação jurídica de acolhimento do pedido, subtrai-se da administração competente - que omitiu o pronunciamento requerido - o poder de determinar $o$ ajustamento das ligações intercorrentes com os particulares, com isto derrogando o princípio geral segundo o qual é a administração pública titular deste poder. ${ }^{125}$

Se até a edição da Lei $\mathbf{8 0 / 2 0 0 5}$ as hipóteses de silêncio-assentimento já eram numerosas, com a edição de referido diploma tornaram-se regra. Seu artigo $3^{\circ}$ estabeleceu:

1. Cada ato de autorização, licença, concessão não-constitutiva, permissão ou alvará como quer que seja denominado, compreendidos os pedidos para inscrição em ordens ou quadros requeridos para o exercício de atividade empresarial, comercial ou artesanal cuja liberação dependa exclusivamente da verificação dos requisitos e pressupostos de lei ou de atos administrativos de caráter geral e para o qual não seja previsto nenhum limite ou contingenciamento global ou instrumentos específicos de programação setorial para a verificação dos mesmos atos, com exclusão dos atos cuja verificação compete à defesa nacional, à administração das finanças, nestes compreendidos os atos concernentes à arrecadação, mesmo a derivada de jogo, à tutela da saúde e da incolumidade pública, do patrimônio cultural e paisagístico e do

\footnotetext{
${ }^{124}$ FRANCO, Italo. Manuale Del Nuovo Diritto Amministrativo. $1^{\mathrm{a}}$ ed. Vicenza: IPSOA, 2007, p. 104 (tradução livre).

${ }^{125}$ DI BENEDETTO, Ugo. Diritto Amministrativo. $3^{\text {a }}$ ed. Santarcangeli di Romagna: Maggiole, 2007, p. 561 (tradução livre).
} 
ambiente, mas também dos atos impostos pelas normas comunitárias, é substituído por uma declaração fornecida pelo interessado, ainda que por meio de auto-certificações, de certificações e das atestações normativas requeridas. A administração competente pode requerer informações ou certificações relativas a fatos, estado ou qualidade, contanto que não estejam atestados em documentos já em posse da própria administração ou não sejam diretamente adquiríveis junto a outra administração pública.

2. A atividade objeto da declaração pode ser iniciada decorridos trinta dias da data de apresentação da declaração à administração competente. Concomitantemente ao início da atividade, o interessado deve expedir comunicação à administração competente.

3. A administração competente, caso verificada a ausência das condições, modalidades e fatos legitimadores, no término de trinta dias do recebimento de que trata o parágrafo 2 , expedirá motivada ordem de proibição de continuidade da atividade e de desfazimento dos respectivos efeitos, salvo se, quando impossível, o interessado providencie a conformação à norma vigente para dita atividade e seus efeitos dentro de um prazo fixado pela administração, em todo caso não inferior a trinta dias. É, porém, ressalvado o poder da administração competente de assumir determinações em via de autotutela, no sentido dos artigos 21-quinquies e 21-novies. Nos casos em que a lei prevê a tomada de pareceres de órgãos ou entidades próprias os prazos para a adoção da ordem de proibição de atividade e de desfazimento de seus efeitos são suspensos, até a apresentação dos pareceres, ao cabo de no máximo trinta dias, após os quais a administração pode adotar os próprios provimentos independentemente da juntada dos pareceres. Da suspensão é dada comunicação ao interessado.

4. Permanecem válidas as disposições da lei vigente que prevejam prazos diferentes daqueles dos parágrafos 2 e 3 para início da atividade e para adoção, pela administração competente, de ordem de proibição e prosseguimento da atividade e de desfazimento de seus efeitos.

5. Toda controvérsia relativa à aplicação dos parágrafos 1,2 e 3 é remetida à jurisdição exclusiva do juiz administrativo ${ }^{126}$.

Elio Casetta explica:

O pressuposto do silêncio-assentimento é aquele segundo a lei efetua uma preliminar valoração abstrata da compatibilidade da atividade privada (conforme descrita no pedido) com o interesse público $^{127}$.

\footnotetext{
${ }^{126}$ Apus DI BENEDETTO, Ugo. Diritto Amministrativo. $3^{\mathrm{a}}$ ed. Santarcangeli di Romagna: Maggiole, 2007, p. 566 (tradução livre).

${ }^{127}$ CASETTA, Elio. Compendio di Diritto Amministrativo. $6^{\mathrm{a}}$ ed. Milano: Giuffrè Editore, 2006, p. 322 (tradução livre).
} 
Vê-se, pois, que o silêncio-assentimento se aplica, como regra, aos provimentos vinculados omitidos pela Administração.

Deve-se ter presente que as declarações inverídicas sujeitam os particulares a sanções previstas em lei, além de impedir a formação do silêncio-assentimento ${ }^{128}$.

Impende ressaltar que os terceiros que se sentirem lesados pelo ato consensual formado pelo silêncio da administração podem ingressar em juízo ${ }^{129}$.

O silêncio sobre recurso hierárquico é a inércia da Administração em apreciar o recurso contra um provimento anterior, com o qual não se conformou o particular. Não se confunde, pois, com os casos de silêncio puro, mas seu estudo se mostra importante, uma vez que a sistemática para suprir o silêncio sobre recurso hierárquico serviu de base para o tratamento da matéria relativa ao silêncio-inadimplemento.

Até 1971, quando promulgada a Lei ${ }^{\circ} 1.199$, que reformou o sistema de recursos administrativos, exigia-se o esgotamento da instância administrativa como condição ao ingresso da demanda no Judiciário.

Para garantir o acesso do particular ao Judiciário a jurisprudência criou um mecanismo, caracterizado por duas fases fundamentais: o decurso de um lapso de tempo razoável, contado da apresentação do recurso administrativo, e a posterior notificação da Administração, advertida a manifestar-se em um novo prazo razoável prefixado. Perdurando a inércia da ao término do prazo, considerava-se formada uma decisão tácita de rejeição. A jurisprudência, contudo, firmou o entendimento de que a formação da decisão de rejeição tácita não impedia que a Administração decidisse expressamente o recurso.

Inicialmente, ingressando o particular em juízo contra a decisão tácita de rejeição, o Judiciário limitava-se a anulá-la por defeito de motivação, cumprindo à Administração

\footnotetext{
${ }^{128}$ CASETTA, Elio. Compendio di Diritto Amministrativo. 6a ed. Milano: Giuffrè Editore, 2006, p. 319 (tradução livre).

${ }^{129}$ FRANCO, Italo. Manuale Del nuovo diritto amministrativo. $1^{\text {a }}$ ed. Vicenza: IPSOA, 2007, p. 112 (tradução livre).
} 
proferir nova decisão, devidamente motivada, contra a qual o particular poderia, novamente, insurgir-se pela via jurisdicional.

Todavia, como a decisão tácita de rejeição implica, na verdade, o acolhimento do primeiro ato, contra o qual o administrado interpusera o recurso administrativo hierárquico, a jurisprudência evoluiu, passando a admitir que o particular impugnasse em juízo este primeiro ato lesivo. Permitia-se ao juiz decidir, então, a substância do conflito entre Administração e administrado - salvo se a pretensão do administrado versasse sobre o mérito do primeiro ato administrativo.

Em 1971, foi editado o d.P.R. ${ }^{130} \mathrm{n}^{\circ} 1.199$, que alterou o tratamento do silêncio sobre recurso administrativo, estabelecendo prazo de noventa dias para a Administração decidir o recurso hierárquico. Findo o prazo, o recurso entender-se-ia rechaçado para todos os efeitos, podendo o interessado impugnar o ato administrativo judicialmente. O objeto da ação judicial, no caso de silêncio referente a recurso hierárquico, não é propriamente o silêncio, sem valor procedimental, mas o ato recorrido, ao qual a decisão omitida estaria, logicamente, correlacionada.

Por fim, para a caracterização do silêncio-inadimplemento ou silêncio-recusa vinha-se adotando, na Itália, até muito recentemente, um procedimento específico, de modo a tornar a inércia administrativa juridicamente relevante. Este procedimento possuía duas fases: a) primeiramente, o pedido do particular visando à obtenção da emanação do provimento, e b) a advertência notificada à Administração por vias judiciais com assinalação explícita de um término prazo final razoável para a emanação do ato.

Tal procedimento tem berço jurisprudencial - o Conselho de Estado começou a tratar do silêncio-recusa de forma semelhante ao silêncio sobre recurso hierárquico (que já vinha regulado, expressamente, pela Lei Comunal e Provincial de 1934), vislumbrando na norma a expressão de um princípio geral idôneo a disciplinar todos os casos de silêncio da Administração.

${ }^{130}$ A sigla significa Decreto Presidencial (Decreto Del Presidente Della Reppublica). 
A distinção entre as hipóteses, porém, é bastante nítida, já que no silêncio sobre recurso hierárquico há uma manifestação expressa da Administração, da qual o particular discorda, enquanto que o silêncio-recusa se forma, exatamente, na hipótese em que falta qualquer tomada de posição da Administração em relação à definição dos interesses em jogo.

Em decorrência desta distinção, começou-se a perceber que o silêncio-recusa deveria ter um tratamento diferente do silêncio sobre recurso hierárquico. A questão ganhou relevo quando, em 1971, sobreveio novo procedimento para este último (como já relatado, passou-se a reconhecer a formação de decisão tácita de rejeição decorridos noventa dias da interposição do recurso), excluindo do procedimento a necessidade da notificação judicial da advertência. Contudo, no silêncio-recusa, em que o fim prioritário é a constrição da Administração a manifestar-se uma primeira vez, a advertência foi considerada um instrumento idôneo de solicitação.

A Lei no 241 de 1990, sobre procedimentos administrativos, não tratou do silêncioinadimplemento, limitando-se a estabelecer a exigência de que cada procedimento seja concluído com uma manifestação expressa dentro de trinta dias ou em outro termo estabelecido pela Administração para cada tipo de procedimento. Com isso, ressurgiu a discussão acerca da necessidade ou não da notificação de uma advertência à Administração. O Ministro da Função Pública expediu a circular nº 60397-7/463, de 8 de janeiro de 1991, esclarecendo que a nova sistemática não incidira sobre o procedimento para tornar relevante o silêncio-recusa.

Também a jurisprudência confirmou a necessidade da prévia advertência como condição para tornar juridicamente relevante o silêncio-inadimplemento. A lei, porém, modificou parcialmente o procedimento, na medida em que o prazo para iniciá-lo passou a ser de trinta dias a contar da solicitação, ressalvada previsão de prazo superior para casos específicos.

A Lei 273, de 11 de julho de 1995, introduziu um novo remédio para a inércia da Administração. Decorrido o prazo de conclusão do procedimento administrativo de 
competência das administrações estaduais, o interessado poderia direcionar um pedido ao dirigente geral, que se manifestaria, diretamente, dentro nos seguintes trinta dias.

A jurisprudência mais recente vinha buscando valorar em termos substanciais, e não meramente formais, a inércia da Administração Pública. Assim, o juízo estender-se-ia a toda a relação administrativa, e o juiz estaria habilitado a manifestar-se sobre a pretensão substancial, quando possível. Mas, quando não contrastante com o ordenamento, a inércia ainda teria de ser caracterizada como comportamento juridicamente relevante - vale dizer, seria necessário seguir o procedimento mencionado, cujo objetivo é obter a pronúncia da Administração.

O decurso do prazo para manifestação, e a realização do procedimento para tornar a inércia juridicamente relevante não retiram da Administração o poder de se manifestar. A caracterização da inércia, porém, ganha relevo para fins penais, civis e disciplinares, bem como o ressarcimento de eventuais danos pelo retardamento da manifestação.

A Lei $n^{\circ} 205$, de 21 de julho de 2000, ditou uma nova disciplina processual, de natureza especial, para a tutela jurisdicional referente ao silêncio da Administração. Criouse um rito mais acelerado para a decisão do mérito, com prazos curtos e previsão de decisão, sucintamente, motivada. Reconhecida a ilegitimidade do silêncio, o juiz anotaria prazo não-superior a trinta dias para que a Administração se manifeste. Não o fazendo, nomearia, a pedido da parte, um comissário, que emanaria o ato, substituindo-se à Administração.

Uma recente discussão da jurisprudência versou sobre o âmbito de alcance da decisão judicial, tendo em vista a nova sistematização do procedimento. Havia duas teses opostas: a primeira sustentava que o recurso contra o silêncio deveria limitar-se ao exame da ilegitimidade da inércia, enquanto que a segunda sustentava que o juiz poderia estender o exame ao fundamento da pretensão substancial do particular. O Conselho de Estado adotou a primeira tese. Como explica Ugo Di Benedetto,

a decisão releva que 'a terminologia usada pelo legislador a qual prevê que o juiz determine à Administração que se manifeste [no original: "ordina di provedere" all'amministrazione] reclama o exercício de uma potestade administrativa, de modo que seria inapropriado se o juiz 
devesse aventurar-se a estabelecer o concreto conteúdo do provimento, pois em tal caso à Administração e ao comissário não restariam espaços senão para uma atividade de conteúdo e função de mera execução. A previsão de um rito acelerado de rapidíssima definição, de resto, seria incompatível com o exame pelo juiz do fundamento da pretensão substancial $^{131}$.

Em suma, o juiz limitar-se-ia a determinar se o silêncio seria ou não ilegítimo, impondo à Administração um prazo para manifestar-se; se esta não o fizesse, seria nomeado um comissário ad acta que exercitaria a potestade administrativa do órgão inadimplente. A decisão foi inovadora, pois, como dito, a jurisprudência até então vinha admitindo o exame da pretensão substancial do particular quando restasse, concretamente, violada uma obrigação de manifestar-se.

Todavia, uma recentíssima lei, de $\mathrm{n}^{\circ} 15$, de 11 de fevereiro de 2005 , eliminou a tradicional exigência de prévia advertência administrativa no recurso contra o silêncio - o que constituía, até então, verdadeiro pressuposto processual - , desde que perdure o inadimplemento e não tenha sido ultrapassado o prazo de um ano do término do prazo para manifestação.

Finalmente, a Lei $\mathbf{n}^{\mathbf{0}} 80$ de 14 de maio de 2005, repetindo os termos da Lei ${ }^{\circ} 15$ (isto é, mantendo a desnecessidade da prévia advertência), acrescentou que o juiz pode conhecer dos fundamentos do pleito, ou seja, pode julgar, substancialmente, a demanda, não se restringindo, necessariamente, a valorar a legitimidade ou ilegitimidade da inércia $^{132}$.

\footnotetext{
${ }^{131}$ DI BENEDETO, Ugo. Diritto Amministrativo. III ed. Santarcangeli di Romagna: Maggiole, 2007, p. 539 (tradução livre).

${ }^{132}$ Art. 3 della legge 14 maggio 2005: Salvi i casi di silenzio-assenso, decorsi i termini di cui ai commi 2 o 3, il ricorso avverso il silenzio dell'amministrazione, ai sensi dell'articolo 21-bis della legge 6 dicembre 1971, n. 1034, può essere proposto anche senza necessità di diffida all'amministrazione inadimpiente, fintanto che perdura l'adimpiemento e comunque non oltre um anno della scadenza dei termini di cui ai predetti commi 2 e 3. Il giudice amministrativo può conoscere della fondatezza dell'istanza. È fatta salva la riproponibilità dell'istanza di avvio del procedimento ovene ricorrani i presuposti.
} 


\subsubsection{O silêncio administrativo no Direito francês}

Em 1975, escreveu Jean Rivero:

Em regra geral, no processo civil o autor pode citar a parte contrária perante o juiz sem a ter previamente avisado da sua intenção e convidado a dar-lhe a satisfação: é o que se chama direito de citação directa.

Perante o juiz administrativo este não existe. $\mathrm{O}$ autor deve dirigirse primeiro à Administração; só se deparar com uma recusa total ou parcial poderá abrir o processo perante o juiz. A regra da decisão prévia é portanto a obrigação imposta ao interessado de, antes de interpor qualquer recurso contra a Administração, solicitar desta uma decisão acerca da pretensão que se propõe submeter ao juiz ${ }^{133}$.

Nesse contexto, ganha indiscutível relevância a questão do silêncio administrativo. A caracterização de uma recusa ou de uma concordância tácita é imprescindível para que o administrado possa defender seu direito em juízo.

Na França, o tema do silêncio administrativo começou a ser tratado em 1900, pela Lei de 17 de julho, segundo a qual o silêncio da Administração sobre recurso a ela dirigido, prolongado por mais de quatro meses, implicaria decisão tácita de rejeição, permitindo ao particular o acesso à via jurisdicional.

A regra foi retomada pela Lei de 7 de junho de 1956 e pelo Decreto de 11 de janeiro de 1965, relativo aos prazos para recurso em matéria administrativa. Atualmente, o tema é objeto da Lei sobre os Direitos dos Cidadãos em suas Relações com as Administrações, de 12 de abril de 2000. Esta lei reduziu de quatro para dois meses a duração do prazo de formação da decisão implícita de rejeição, com o objetivo de acelerar o curso dos procedimentos.

René Chapus escreve:

133 RIVERO, Jean. Ehrdaedt Soares, Rogério (trad.). Direito Administrativo. Coimbra: Almedina, $1981, \mathrm{p}$. 248. 
A regra assimilando, assim, o silêncio à rejeição (ou à recusa) se aplica largamente: de um lado, os casos em que o silêncio equivale a uma decisão de aceitação têm um caráter derrogatório; de outro lado, aqueles em que a administração é obrigada a decidir explicitamente são excepcionais.

Em conseqüência desta regra, a administração não pode, se abstendo de decidir explicitamente, obstaculizar o exercício ao recurso judicial (que em princípio deve ser dirigido contra uma decisão) e é nisto que reside sua razão de ser.

Mas, graças a ela, a administração pode deixar de decidir explicitamente quando uma decisão explícita de rejeição seria difícil de tomar ou motivar. O tempo trabalhará em seu lugar ${ }^{134}$.

Para que se caracterize o silêncio administrativo no Direito francês, é necessário que o pedido seja dirigido à autoridade competente. Mas, como o administrado pode não saber, exatamente, qual é a autoridade competente, a regra tem sido flexibilizada. A autoridade incompetente deve transmitir o pedido à autoridade competente. Cuida-se de obrigação criada pela jurisprudência, explicitada pelo Decreto de 28 de novembro de 1983 e pela Lei de 12 de abril de 2000, que generalizou tal dever, à exceção das demandas concernentes às relações entre a Administração e seus agentes.

O referido prazo de dois meses, necessário para a caracterização da decisão implícita de rejeição, pode sofrer variações. Assim, por exemplo, em se cuidando de pedido de comunicação de documentos, o prazo é de apenas um mês. De outro lado, em se tratando de casos complexos, como autorização de criação ou ampliação de estabelecimentos de saúde, o prazo é de seis meses.

De acordo com a Lei de 12 de abril, o prazo corre a contar do recebimento do pedido, ainda que dirigido a uma autoridade incompetente, desde que haja o dever de remetê-lo à competente. $\mathrm{O}$ prazo não se interrompe ou suspende, nem mesmo por pedidos de justificação, se porventura endereçados pela Administração ao cidadão. "Vale dizer", observa René Chapus, “que 'silêncio de dois meses' (ou de outra duração) significa 'ausência de decisão explícita durante dois meses"”135. Phillippe Foillard, porém, apresenta uma exceção:

\footnotetext{
${ }^{134}$ CHAPUS, René. Droit administratif général. Tome 1. $15^{\text {a }}$ ed. Paris: Montchrestien, 2001, p. 506 (tradução livre).

${ }^{135}$ CHAPUS, René. Droit administratif général. Tome 1. $15^{\text {a }}$ ed. Paris: Montchrestien, 2001, p. 507 (tradução livre).
} 
Todavia, o decreto de 6 de junho de 2001, editado para a aplicação da lei de 12 de abril de 2000, previu uma exceção: quando o pedido formulado por um administrado estiver incompleto, a administração pode suspender o intervalo ao fim do qual nasce a decisão implícita. O Conselho de Estado, admitindo a legalidade deste mecanismo, estabeleceu que a administração não poderia dele abusar para retardar a data da formação de uma decisão (CE, 13 de janeiro de 2003, M. Camara e outros, AJDA de 24 de fevereiro de 2003, p. 327). ${ }^{136}$

A regra no Direito francês é, pois, que o silêncio da Administração gera a recusa do pedido. Mas há hipóteses em que a consequiência é uma decisão implícita de aceitação. Cuida-se de situações previstas em diplomas esparsos, derrogatórias da regra geral de rejeição do pedido. Phillippe Foillard assevera que se cuida de regras que visam a tornar as decisões administrativas mais rápidas, bem como a suavizar o trabalho da Administração ${ }^{137}$. Comumente, dizem respeito a questões de urbanismo e uso do solo, como permissões tácitas de construir ou demolir, de exploração de minas. René Chapus estima em não menos de quatrocentas as regras de aceitação tácita no sistema francês ${ }^{138}$. E pontifica:

Sem ser, evidentemente, desfavorável aos administrados demandantes, este sistema torna mais leve o trabalho da administração e permite, freqüentemente, decisões em intervalos mais breves daqueles que seriam necessários para a elaboração de decisões explícitas.

$$
\text { (...) }
$$

De maneira geral, é preciso ser sensível ao fato de que, da técnica da decisão implícita de aceitação, pode resultar a criação de direitos e de situações irreversíveis; isto explica certas precauções e exigências não comportadas pelo regime de constituição das decisões implícitas de rejeição, e que são destinadas a permitir tanto quanto possível à administração tomar uma decisão expressa de rejeição, se estimar que a demanda não é justificada ${ }^{139}$.

Os requisitos para a ocorrência de uma decisão implícita de aceitação são: a) dirigir o pedido a uma autoridade competente, ou a autoridade incompetente que tenha o dever de remetê-lo à competente, contando-se o prazo a partir da chegada do pedido a esta última; b) instruir o pedido com todas as peças exigidas pelas leis e regulamentos, sob pena de o prazo não começar a correr; c) aguardar o término do prazo, que pode ser de dois meses,

\footnotetext{
${ }^{136}$ FOILLARD, Philippe. Droit administratif. 12ª ed. Orléans: Paradigme, 2007, p. 188 (tradução livre).

${ }^{137}$ FOILLARD, Philippe. Droit administratif. 12a ed. Orléans: Paradigme, 2007, p. 188.

${ }^{138}$ CHAPUS, René. Droit administratif général. Tome 1. 15a ed. Paris: Montchrestien, 2001, p. 508.

${ }^{139}$ CHAPUS, René. Droit administratif général. Tome 1. $15^{\mathrm{a}}$ ed. Paris: Montchrestien, 2001, p. 508/509 (tradução livre).
} 
como prevê a Lei de 12 de abril, ou outro, geralmente dado por decretos do Conselho de Estado.

É interessante lembrar que, embora as situações nas quais o silêncio equivale à aceitação do pedido estejam previstas em regras esparsas no ordenamento jurídico francês - e não apenas em leis, mas também em decretos do Conselho de Estado - a Lei de 12 de abril trouxe previsão geral sobre o tema. Isso porque, contrariamente ao Conselho de Estado, o Conselho Constitucional via na regra um princípio geral de direito, razão pela qual só poderia ser afastado por meio de lei. Gilles Lebreton explica que

para regularizar as derrogações já estabelecidas por via regulamentar, a lei de 2000 esclarece que os decretos do Conselho de Estado podem prevê-las, e estimar que o silêncio da administração equivale a decisão implícita de aceitação $^{140}$.

No Direito comum francês, o prazo para interposição de um recurso judicial contra as decisões administrativas é de dois meses. No caso das decisões implícitas de rejeição, o prazo só começa a correr ao cabo dos dois meses de silêncio da Administração. Nas hipóteses de decisão implícita de aceitação, o prazo só começa a correr, para terceiros, a partir da publicação da decisão. Observa Philippe Foillard:

Ora, uma decisão implícita não podendo (por definição) ser publicada (salvo se um documento materializa a decisão: a carta de um prefeito valendo a permissão de construir tácita que o destinatário pode afixar para conhecimento de terceiros), acontece freqüentemente que o prazo não começa jamais a correr ${ }^{141}$.

\footnotetext{
${ }^{140}$ LEBRETON, Gilles. Droit Administratif Général. $4^{\mathrm{a}}$ ed. Paris: Dalloz, 2007, p. 235 (tradução livre).
}

${ }^{141}$ FOILLARD, Philippe. Droit administratif. 12ª ed. Orléans: Paradigme, 2007, p. 347 (tradução livre). 


\subsubsection{O silêncio administrativo no Direito português}

No Direito lusitano, a regra é que a consequiência do silêncio administrativo é o indeferimento da pretensão (artigo $109^{\circ}$ do Código de Procedimento Administrativo). Em determinados casos, porém, a legislação atribuía à inércia administrativa o caráter de aprovação (artigo $108^{\circ}$ do Código de Processo Administrativo). Como explica Marcello Caetano, isso ocorre "quando estão em causa interesses públicos, como sucede na tutela administrativa, ou quando se procura acelerar o funcionamento da Administração, como sucede no processo de licenciamento municipal de obras particulares" ${ }^{\text {"142 }}$.

Os mencionados artigos de lei têm a seguinte redação:

Artigo 108.

Deferimento tácito

1-Quando a prática de um acto administrativo ou o exercício de um direito por um particular dependam de aprovação ou autorização de um órgão administrativo, consideram-se estas concedidas, salvo disposição em contrário, se a decisão não for proferida no prazo estabelecido por lei.

2-Quando a lei não fixar prazo especial o prazo de produção do deferimento tácito será de 90 dias a contar da formulação do processo pelo dito ou da apresentação do processo para esse efeito.

3-Para os efeitos do disposto neste artigo, consideram-se dependentes de aprovação ou autorização de órgão administrativo para além daquela relativamente aos quais leis especiais prevejam o deferimento tácito, os casos de:

a) Licenciamento de obras particulares;

b) Alvarás de loteamento;

c) Autorizações de trabalho concedidas a estrangeiros;

d) Autorizações de investimento estrangeiro;

e) Autorização para laboração contínua;

f) Autorizações de trabalho por turnos;

g) Acumulações de fusões públicas e privadas.

4-Para o cômputo dos prazos previstos nos n. ${ }^{\circ} \mathrm{s} 1$ e 2 considera-se que os mesmos se suspendem sempre que o procedimento estiver parado por motivo imputável ao particular.

${ }^{142}$ CAETANO, Marcello. Manual de Direito Administrativo. Vol. I. 10ª ed. Coimbra: Almedina, 2005, p. 475 . 
Artigo 109.

Indeferimento tácito

1-Sem prejuízo do disposto no artigo anterior, a feita, no prazo fixado para a sua emissão, de decisão final sobre a pretensão dirigida a órgão administrativo competente confere ao interessado, salvo disposição em contrário, a faculdade de presumir indeferida essa pretensão, para poder exercer o respectivo meio legal de impugnação.

2-O prazo a que se refere o número anterior é, salvo o disposto em lei especial, de 90 dias.

3-Os prazos deferidos no número anterior contam-se, na falta de disposição especial:

a) Da data de entrada do requerimento ou petição no serviço competente, quando a lei não imponha formalidades especiais para a fase preparatória da decisão;

b) Do termo do prazo fixado na lei para a conclusão daquelas formalidades ou, na falta de fixação, do termo dos três meses seguintes à apresentação da pretensão;

c) Da data do conhecimento da conclusão das mesmas formalidades, se essa for anterior ao termo do prazo aplicável de acordo com a alínea anterior.

Como se nota, a legislação portuguesa é bastante exaustiva acerca da consequiência do silêncio administrativo. Sendo assim, havendo omissão administrativa, a doutrina portuguesa entende que ocorre o chamado ato tácito. Na lição de Marcello Caetano:

A manifestação tácita de vontade, em Direito Administrativo, resulta de presunções legais juris et de jure que dão origem a actos simples: a lei, em certas circunstâncias, manda interpretar para certos efeitos a passividade ou o silêncio de um órgão administrativo como significando o deferimento ou o indeferimento do pedido sobre o qual ele tinha obrigação de se pronunciar.

Isto é, de um facto conhecido (o silêncio de um órgão que podia e devia manifestar-se) a lei manda inferir uma conclusão (o deferimento ou indeferimento) independentemente da intenção que porventura tenha havido na manutenção do silêncio.

A conduta passiva ou silenciosa do órgão da Administração é voluntária, mesmo quando fruto da simples negligência ou do desleixo, desde que estivesse nas possibilidades desse órgão conduzir-se doutra maneira se quisesse ${ }^{143}$.

Impõe-se ressaltar que o referido autor denomina atos jurídicos simples àqueles que se produzem independentemente da previsão ou volição do resultado jurídico, em

${ }^{143}$ CAETANO, Marcello. Manual de Direito Administrativo. Vol. I. 10 a ed. Coimbra: Almedina, 2005, p. 474. 
oposição aos atos jurídicos intencionais, cuja perfeição exige que o agente tenha querido o resultado jurídico decorrente de sua conduta ${ }^{144}$.

Mário Esteves de Oliveira, Pedro Costa Gonçalves e J. Pacheco de Amorim, comentando as hipóteses de deferimento tácito, anotam:

Nos casos a que se reporta o preceito, o acto tácito (formado legalmente a partir do silêncio do órgão competente durante determinado prazo) consistente na aprovação ou autorização pedidas (propostas ou requeridas).

Trata-se, para todos os efeitos, de um acto administrativo, correspondente àquele que resultaria de a Administração ter decidido expressamente "aprovo" ou "autorizo". Ou seja, noutra perspectiva, o exercício do direito pelo requerente fica, a partir daí, administrativamente descondicionado (mesmo não havendo acto expresso descondicionante).

A produção do acto de deferimento (de descondicionamento) tácito depende da congregação de diversos requisitos ou pressupostos, positivos, uns, negativos, os outros.

Exige-se, antes de tudo, que tenha sido formulada uma pretensão estando implícito na previsão legal que se trata de pretensões formuladas aos órgãos competentes para as apreciar - e que não haja decisão expressa ou implícita (pressuposta) sobre o conteúdo dessa pretensão, em determinado prazo.

Não são, porém, apenas esses os pressupostos a atender, quando se configura o silêncio da Administração com um acto de efeitos positivos.

Desde logo, há de tratar-se de um caso legalmente previsto, como sendo de deferimento tácito, seja através de cláusula geral e/ou de disposição específica da lei (...).

Por outro lado, embora o legislador não precisasse, talvez, de dizêlo, não pode esquecer-se que só há acto tácito, quando estiverem preenchidos todos os pressupostos procedimentais (...), ou seja - para além da pretensão (inteligível), da competência e da inexistência de decisão expressa, também - a legitimidade do requerente, a tempestividade do pedido, a actualidade (não caducidade) do direito e a existência de um dever legal de decidirência de um dever legal de decidir ( que não existiria se, por exemplo, sobre o mesmo assunto, houvesse decisão há menos de dois anos, cfr. $\mathrm{N}^{\circ} 2$ do art. $\left.9^{\circ}\right)^{145}$.

Resumindo, didaticamente, os requisitos cuja ocorrência deve se verificar a fim de que tenha origem um ato tácito, Marcello Caetano arrola:

\footnotetext{
${ }^{144}$ CAETANO, Marcello. Manual de Direito Administrativo. Vol. I. 10 a ed. Coimbra: Almedina, 2005, p. 423.

${ }^{145}$ OlIVEIRA, Mario Esteves de, GONÇALVES, Pedro Costa e AMORIM, J. Pacheco. Código do Procedimento Administrativo Comentado. $2^{\mathrm{a}}$ ed. Coimbra: Almedina, 2006, pp. 484/485.
} 
$1^{\circ}$ que o órgão administrativo seja solicitado a manifestar-se, num caso concreto;

$2^{\circ}$ que a pretensão apresentada verse matéria de competência desse órgão; $3^{o}$ que o órgão tenha o dever legal de resolver em certo prazo o caso apresentado, mediante a prática tenha dum acto definitivo, o que quer dizer que o poder de decidir deve ser vinculado quanto à oportunidade de seu exercício;

$4^{\circ}$ que a lei atribua à abstenção de resolução dentro do prazo legal um significado determinado ${ }^{146}$.

O doutrinador ainda conclui que "o silêncio, quando não haja a possibilidade física de expressão ou dever legal de declaração da vontade em certo prazo, não é relevante em Direito Administrativo" 147.

O Código de Procedimento Administrativo luso (Decreto-Lei 442/91, de 15 de novembro), se elege como princípio o da obrigatoriedade da decisão, também contempla exceção à regra:

\begin{abstract}
Artigo $9^{\circ}$
Princípio da decisão

1 - Os órgãos administrativos têm, nos termos regulados neste código, o dever de se pronunciar sobre todos os assuntos da sua competência que lhes sejam apresentados pelos particulares e, nomeadamente:

a) Sobre os assuntos que lhes disserem directamente respeito;

b) Sobre quaisquer petições, representações, reclamações ou queixas formuladas em defesa da Constituição, das leis e do interesse geral.

2 - Não existe o dever de decisão quando, há menos de 2 anos contados da data da apresentação do requerimento, o órgão competente tenha praticado um acto administrativo sobre o mesmo pedido formulado pelo mesmo particular com os mesmos fundamentos.
\end{abstract}

O segundo item do artigo explicita, pois, hipóteses de inexistência legal do dever de decidir, quando, então, o silêncio não seria relevante.

Ressalte-se que o ato tácito tem grande relevância no Direito lusitano, justamente porque se exige, para ingresso no contencioso administrativo, que haja um provimento da

\footnotetext{
${ }^{146}$ CAETANO, Marcello. Manual de Direito Administrativo. Vol. I. 10 a ed. Coimbra: Almedina, 2005, p. 475

${ }^{147}$ CAETANO, Marcello. Manual de Direito Administrativo. Vol. I. 10ª ed. Coimbra: Almedina, 2005, p. 475
} 
Administração. Aliás, a figura do ato administrativo tácito foi criada, justamente, para permitir o acesso à via jurisdicional.

Vale transcrever ementa de acórdão do Supremo Tribunal Administrativo. O julgado é bastante interessante: no item I, faz referência aos dois anos que prevê o Código de Processo Administrativo (prazo dentro no qual não haveria obrigatoriedade de manifestação por parte da Administração); no item II, explicita a ratio do ato tácito no Direito português.

I - A formulação de idêntico pedido, com os mesmos fundamentos, à mesma entidade, desde que competente, decorridos dois anos sobre a prolação de acto expresso de indeferimento é, em princípio, susceptível de gerar indeferimento tácito, nos termos do art. 9, n. 2 do CPA.

II - A figura do indeferimento tácito é um expediente processual que visa obstar a que uma omissão da Administração, lesiva de direitos ou interesses legalmente protegidos do particular, seja insusceptível de impugnação contenciosa.

III - Todavia, se o acto expresso anterior, que indeferiu pretensão do recorrente, se firmou na ordem jurídica, por falta de atempada impugnação, o silêncio da Administração sobre a renovação dessa pretensão, não tendo entretanto ocorrido qualquer alteração das circunstâncias de facto e de direito, não tem conteúdo inovatório, lesivo da esfera jurídica do recorrente, sendo, por isso, impossível a sua impugnação ao abrigo do art. 109 do CPA.

(Supremo Tribunal Administrativo, $1^{\text {a }}$ Subseção do CA; Relator Abel Atanásio, processo $\mathrm{n}^{\circ} 039417$ )

O aperfeiçoamento de um ato tácito não impede a Administração de produzir outro, expresso, pois aquele não esgota a competência do órgão. Não será possível, porém, praticar ato contrário ao tácito se este for constitutivo de direitos. 


\subsubsection{O silêncio administrativo no Direito espanhol}

No Direito espanhol, admite-se que o silêncio possa gerar atos administrativos presumidos.

Rafael Entrena Cuesta explica que, "historicamente, a doutrina do silêncio administrativo surge como conseqüência da necessidade de salvaguardar os interesses dos administrados perante a Administração", já que, para se interpor recurso nas vias administrativa e contenciosa exige-se um ato prévio ${ }^{148}$.

Segundo escreve Ramón Parada,

formalmente, a falta de resposta, o silêncio da Administração, diante de uma petição ou recurso de um particular não é um ato, mas um fato jurídico, pois falta a declaração de vontade dirigida a produzir efeitos jurídicos como é próprios dos atos expressos. O silêncio é o comportamento do que não manifesta nenhuma vontade; qui tacet neque negat, neque utique facetur ${ }^{149}$.

O autor explica que, no Direito Privado, a regra é que o silêncio de uma parte frente à demanda de outra, se a primeira deveria manifestar-se (elemento objetivo) e tinha conhecimento dos elementos que poderiam levá-la a negar o pedido (elemento subjetivo), faz presumir seu assentimento. E anota:

No Direito administrativo, sem embargo, e com objetivo de assegurar o direito à garantia jurisdicional, o acesso ao processo ou mesmo a efetividade de outros direitos de caráter substantivo que podem resultar bloqueados pela inatividade da Administração, atribui-se ao silêncio o valor de uma decisão de significado às vezes negativo ou denegatório e outras vezes de provimento ou positivo. Daí de falar de duas classes de silêncio: negativo e positivo ${ }^{150}$.

\footnotetext{
${ }^{148}$ CUESTA, Rafael Entrena. Curso de Derecho Administrativo. $5^{\mathrm{a}}$ ed. Madri: Editorial Tecnos, 1976, p. 517 (tradução livre).

${ }^{149}$ PARADA, Ramón. Derecho Administrativo. I Parte general. 9a ed. Madrid: Marcial Pons, 1997, p. 119 (tradução livre). Diversa é a posição de seu conterrâneo Rafael Entrena Cuesta, para quem o silêncio constitui verdadeiro ato administrativo (presumido embora). Remete-se o leitor ao item 2 deste capítulo, acerca da natureza jurídica do silêncio.

${ }^{150}$ PARADA, Ramón. Derecho Administrativo. I Parte general. $9^{\mathrm{a}}$ ed. Madrid: Marcial Pons, 1997, p. 119 (tradução livre).
} 
Ressalte-se que, como ensina Rafael Entrena Cuesta, é pressuposto da aplicação da teoria do silêncio administrativo que se formule perante a Administração uma petição e que esta tenha o dever de decidir. Assim, a doutrina não se aplica às "petições graciosas, já que em relação a elas o único dever que pesa sobre o órgão a que se dirigem é de acusar o recebimento daquelas" ${ }^{\prime 151}$.

Consoante anota Ramón Parada, o tratamento do silêncio no Direito espanhol experimentou uma evolução. A falta de resposta da Administração teve, normalmente, um significado negativo ou de denegação do recurso interposto pelo particular. Esta ficção legal abria ao administrado as vias de recurso administrativo ou judicial. Assim, cumpriase a regra de que o processo contencioso necessita de um ato.

Rafael Entrena Cuesta leciona, acerca dos primórdios da teoria do silêncio administrativo na Espanha:

Chegando-se, pois, ao convencimento de que a tutela dos direitos individuais impõe a exigência da presunção, se apresentava um novo problema: que significado atribuir ao silêncio administrativo. A resposta a esta questão foi resolvida em favor do caráter denegatório do ato presumido, por se estimar que, em caso contrário, a mera negligência de um funcionário ao tramitar um expediente poderia determinar a transferência aos particulares de situações, direitos ou prerrogativas próprios da Administração, por sua conexão com o domínio público ou o serviço público (s. de 12 de outubro de 1963$)^{152}$.

Com base nesta lógica, a primeira regulação do silêncio administrativo, constante do artigo 94 dos Estatutos Municipal y Provincial de Calvo Sotelo de 1924, previu que, quando formulada uma petição perante a Administração e não respondida esta no prazo de três meses, o interessado poderia denunciar a mora e, transcorridos três meses a contar da denúncia, poderia considerar denegada a pretensão, permitindo-se-lhe deduzir perante esta denegação presumida o correspondente recurso administrativo ou jurisdicional - ou ainda esperar a apreciação expressa de sua petição. Na via recursal não havia necessidade de denúncia da mora (aplicada a regra dies interpelat pro homine); isto é, interposto recurso

\footnotetext{
${ }^{151}$ CUESTA, Rafael Entrena. Curso de Derecho Administrativo. $5^{\mathrm{a}}$ ed. Madri: Editorial Tecnos, 1976, p. 519 (tradução livre).

${ }^{152}$ CUESTA, Rafael Entrena. Curso de Derecho Administrativo. $5^{\text {a }}$ ed. Madri: Editorial Tecnos, 1976, p. 518 (tradução livre).
} 
administrativo, e não apreciado este no prazo de três meses, considerava-se-o rejeitado (podendo o administrado, todavia, aguardar seu julgamento expresso).

Excepcionando a regra de que o silêncio administrativo implicava rejeição do pedido, a Lei de Procedimento Administrativo de 1958 atribuiu à inércia da Administração caráter positivo nas hipóteses de autorizações ou aprovações que devessem ser concedidas no exercício das funções de fiscalização, e nos casos de tutela dos órgãos superiores sobre os inferiores. Isso porque, na lição de Rafael Entrena Cuesta,

A atribuição de um valor negativo ao silêncio careceria de sentido quando se postula simplesmente o exercício de uma situação de poder de que era titular o peticionário. É dizer, ao solicitar uma permissão ou licença: em tal caso, quebram-se os argumentos que acabamos de compilar e a lógica exige que se presuma a existência de um ato positivo. Desta forma, toma espaço a idéia de atribuir, excepcionalmente, ao silêncio um valor positivo ${ }^{153}$.

Assim, nas relações entre a Administração e os administrados o silêncio somente se entenderia positivo se houvesse uma disposição expressa que previsse tal conseqüência como ocorria, por exemplo, no transcurso do lapso de seis meses, sem resposta pela autoridade superior, após o que se consideravam aprovados os planos de urbanismo.

O Real Decreto-Ley 1, de 14 de março de 1986, estendeu o silêncio positivo às licenças e autorizações de instalação ou ampliação de empresas ou centros de trabalho. Nestes casos, transcorridos dois meses da apresentação da solicitação e remanescendo inerte a Administração, considerava-se ter havido aprovação, sempre que os interessados houvessem apresentados suas petições, devidamente documentadas, e estas se ajustassem ao Ordenamento Jurídico. Foram excepcionadas as licenças relacionadas à fabricação de armas, explosivos e indústrias de interesse militar, bem como bancos e caixas econômicas, entidades de crédito, fundos de investimento e de gestão de patrimônio, hidrocarbonetos, resíduos tóxicos, empresas de segurança, jogo e transporte aéreo e terrestre.

Consoante lição de Ramón Parada,

${ }^{153}$ CUESTA, Rafael Entrena. Curso de Derecho Administrativo. $5^{\mathrm{a}}$ ed. Madri: Editorial Tecnos, 1976, p. 518 (tradução livre). 
O Tribunal Supremo precisou que os prazos do silêncio positivo hão de computar-se da forma mais desfavorável à Administração infratora do dever de resolução expressa. Assim, o cômputo se inicia desde o momento mesmo da apresentação da solicitação, projeto ou proposta, prazo que é mister completar antes que se produza não a resolução tardia, mas sua notificação. De outra parte, a interrupção produzida por ordens da Administração para correção de quaisquer defeitos nas solicitações ou projetos apresentados implica que é necessário começar, a partir do saneamento, um novo cômputo do total do prazo. Pelo contrário, a Jurisprudência entendia que não se tratava de um prazo de prescrição, mas de caducidade, e que, em conseqüência, saneados os defeitos, só era necessário completar o tempo restante do prazo (Sentenças de 16 de março de 1973 e 16 de março de 1974) ${ }^{154}$.

O autor diz haver um risco na técnica do silêncio positivo. É que, como os atos declaratórios de direitos não podem ser revogados a posteriori senão mediante procedimentos complexos, com efeitos limitados. E relata como os espanhóis tentaram solucionar esta questão:

Nesta linha, o Tribunal Supremo havia aceitado a revogação direta sem sujeição aos trâmites de revogação direta sem sujeição aos trâmites de revogação dos atos declaratórios de direitos das licenças e autorizações obtidas por silêncio quando sua outorga implica nulidade de pleno direito, seja por concorrerem vícios essenciais de tramitação, seja porque o ordenamento qualifica o efeito ou resultado outorgado por silêncio como nulo de pleno direito, ou quando o obtido por silêncio for ostensiva e manifestamente ilegal, como ocorre com as licenças urbanísticas de construção sobre áreas verdes (Sentenças de 4 de fevereiro de 1977, 24 de outubro de 1978, 24 de dezembro de 1979 e 22 de outubro de 1981). Mais restritivamente ainda, o artigo 78 da Lei do Solo limitou os efeitos das licenças obtidas por silêncio positivo aos que são conformes com o ordenamento jurídico, de tal maneira que naqueles extremos em que as petições ou projetos extravasarem a norma ou o plano pelo qual deviam reger-se, o silêncio da Administração não comporta assentimento nem, por ele, se entende produzida a licença ou autorização ("en ningún caso se entenderán adquiridas por silencio administrativo faculdades em contra de las prescripciones de esta Ley, de los planes, proyectos, programas $\mathrm{y}$, en su caso, de las normas complementarias y subsidiarias del planamiento" $)^{155}$.

Em 1992, houve um novo regramento sobre o silêncio administrativo. A Lei 30/1992, muito criticada pela doutrina espanhola, alterou o tratamento anterior do tema. Enquanto que até então o escopo do legislador era deixar caracterizado o ato presumido

\footnotetext{
${ }^{154}$ PARADA, Ramón. Derecho Administrativo. I Parte general. $9^{\mathrm{a}}$ ed. Madrid: Marcial Pons, 1997, p. 121 (tradução livre).

${ }^{155}$ PARADA, Ramón. Derecho Administrativo. I Parte general. $9^{\mathrm{a}}$ ed. Marcial Pons: Madrid, 1997, pp. 121122 (tradução livre).
} 
negativo, de forma a permitir ao administrado o acesso à Justiça ou a interposição de recursos administrativos, a nova lei estabeleceu a responsabilidade disciplinar do funcionário responsável pela emanação do ato, findo o prazo para manifestação - que foi reduzido para três meses, excepcionalmente prorrogável por mais três -, havendo o silêncio caráter positivo ou negativo, conforme a determinação prévia de cada Administração ou, à míngua desta, de acordo com a distribuição de matérias estabelecida pela própria lei. Mas para a caracterização do silêncio não basta o transcurso do prazo; é necessário, ainda, dirigir-se ao órgão silente e dele obter uma certidão de que o silêncio se verificou, a qual indicará quais os efeitos dele derivados. A certidão é emitida pelo próprio funcionário que omitiu o ato - emissão esta indelegável -, sob pena de incorrer em infração disciplinar grave. Com esta certidão o administrado pode ingressar com os recursos administrativos ou judiciais ou, ainda, exercer o direito, se se tratar de um silêncio positivo. Todavia, ainda que caracterizado o ato presumido positivo, este pode não ser reconhecido pela Administração, se o reputar nulo de pleno direito, por inobservância das condições essenciais para sua aquisição.

Sobre as novas regras, Ramón Parada tece as seguintes críticas:

Estas complicadas regras formais e a repressão sobre os funcionários não têm presente as dificuldades que pode exigir a resolução de procedimentos em numerosas matérias administrativas, pelo que constitui um simplismo estabelecer um prazo único para a resolução de todos os procedimentos administrativos. Há expedientes que podem e devem resolver-se em horas, mas outros, por sua natureza, exigem até anos. Ademais, o bom e rápido funcionamento da Administração depende, sem dúvida, do comportamento e espírito de serviço dos funcionários, mas antes de tudo pela eficaz direção que se exerce desde a instância política (...). Se a causa, pois, dos atrasos não está unicamente nos funcionários que os têm a seu encargo, e se apesar disto se pressiona injustamente sobre estes com ameaças de responsabilidade, ficam impelidos a preparar soluções precipitadas, mas, em todo caso, denegatórias e contrárias aos administrados, porque estas soluções são precisamente aquelas em que não incorrem em responsabilidade, responsabilidade que lhes podem exigir seus superiores se não resolvem no prazo, ou resolvam dentro dele, mas a favor do cidadão e, ao menos aparentemente, contra o interesse público (se deixa, por exemplo, de sancionar ou se concede ou autoriza uma subvenção etc. $)^{156}$.

O autor, ainda, observa que a obrigação de o funcionário emitir certidão de que conste sua própria falta funcional (a indevida omissão) é de duvidosa constitucionalidade,

${ }^{156}$ PARADA, Ramón. Derecho Administrativo. I Parte general. 9a ed. Madrid: Marcial Pons, 1997, p. 123. 
pois fere o direito à não-auto-incriminação, garantido pelo artigo 24 da Constituição espanhola $^{157}$.

Em síntese, a doutrina aponta que as novas regras burocratizaram a caracterização do silêncio administrativo e criaram instrumentos de pressão sobre aqueles que não têm, necessariamente, a potestade de resolver, sozinhos, os expedientes administrativos. Além disso, os detentores de cargos da cúpula governamental, como Secretários e Ministros, por não serem funcionários no sentido técnico do termo, não estão submetidos às sanções disciplinares da lei.

Ademais, os doutrinadores espanhóis também viram com desconfiança a possibilidade de cada Administração determinar quais atos sejam presumidos positivos ou negativos, que criaria uma insegurança jurídica, pois cada um dos mais de nove mil Municípios espanhóis teria liberdade para tratar o assunto de uma maneira diferente restando ao administrado averiguar, no caso concreto, qual a solução que prevê o ordenamento de cada uma...

A lei nacional estabelece, contudo, algumas regras gerais, a serem aplicadas quando não houver previsão na lei local. De acordo com essas regras gerais, considera-se o silêncio como concessão do pedido nos seguintes casos: a) solicitações ou concessões de licença e autorizações de instalação, transferência ou ampliação de empresas ou centros de trabalho; b) solicitações cuja estimação habilitaria ao solicitante apenas o exercício de direitos préexistentes, salvo se a concessão tiver como consequiência que se transfiram, ao solicitante ou a terceiros, faculdades relativas ao domínio público, caso em que se considerarão denegadas; c) nos demais casos, as solicitações cujas normas não estabeleça que restam denegadas na falta de provimento expresso (vale dizer, a lei estatui o silêncio positivo como regra).

De outra parte, entende-se ter havido a denegação nas seguintes hipóteses: a) procedimentos de exercício do direito de petição do artigo 29 da Constituição; b) resolução de recursos administrativos, salvo se interposto contra o ato negativo presumido, caso em que o decurso do prazo para apreciação do recurso significa seu provimento.

${ }^{157}$ PARADA, Ramón. Derecho Administrativo. I Parte general. 9a ed. Madrid: Marcial Pons, 1997, p. 124. 
A Lei 30/1992 estende as regras referentes ao silêncio para os procedimentos administrativos iniciados de ofício pela autoridade administrativa - o que, aponta a doutrina, é um desvirtuamento do conceito.

A certidão da ocorrência do silêncio, que indica quais seus efeitos, é, na prática, um ato administrativo expresso (o que não deixa de ser uma negação da técnica do tratamento do silêncio administrativo). Por esta razão, a lei não permite, depois de emitida a certidão, que se emita outro ato resolutivo expresso ${ }^{158}$.

\footnotetext{
${ }^{158}$ No sistema anterior à alteração legislativa, observara Rafael Entrena Cuesta: "Respecto del silencio negativo, hay que hacer, sin embargo, una advertencia: como la denegatión presunta no excluirá el deber de a Administración de dictar una resolución expressa (art. 94, 3, L.P.A.), los interessados pueden esperar a que se resuelva expressamente (art. 94, L.P.A., ySs. De 22 de enero y 15 de febrerero de 1960)". CUESTA, Rafael Entrena. Curso de Derecho Administrativo. $5^{\text {a }}$ ed. Madri: Editorial Tecnos, 1976, p. 525.
} 


\subsubsection{O silêncio administrativo no Direito argentino}

No Direito argentino, fala-se que a Administração tem o privilégio do silêncio, significando que a ela não se aplica a regra do Direito Privado, que reconhece haver consentimento tácito diante de determinadas condições ${ }^{159}$.

Juan Carlos Cassagne escreve:

$\mathrm{Na}$ ordem nacional, em concordância com o sustentado pela doutrina, admite-se que a conduta omissiva ou ambígua da Administração, quando se requeira dela um pronunciamento concreto, seja interpretada como negativa, regulamentando a lei os distintos termos em que se configura o silêncio dentro do procedimento administrativo. Neste sentido a norma legal exige a intervenção ativa do administrado ao obrigá-lo a requerer imediato despacho frente à inatividade da Administração como condição para que se opere o silêncio, salvo se uma norma especial preveja um prazo expresso dentro no qual a Administração deva emitir um pronunciamento concreto ${ }^{160}$.

No Direito argentino, a regra é o silêncio negativo. Fernando E. Juan Lima aponta que

a figura do silêncio positivo, cujo campo natural de aplicação se insere no âmbito da denominada atividade de polícia ou de controle mediante a autorização de atividades privadas, não tem recebido fácil aceitação e somente foi prevista em limitadíssimas hipóteses ${ }^{161}$.

O artigo 10 da LNPA (Ley Nacional de Procedimientos Administrativos) prescreve

que:

Somente mediante disposição expressa poderá corresponder ao silêncio sentido positivo. Se as normas especiais não previrem um prazo determinado para o pronunciamento, este não poderá exceder a sessenta

\footnotetext{
${ }^{159}$ Art. 1.146 do Código Civil argentino: El consentimiento tacito se presumirá si una de las partes entregar, y la otra ricibier la cosa ofrecida o pedida; o si una de las partes hiciere lo que no hubiere hecho si su intención fuese no aceptar la propuesta u oferta.

${ }^{160}$ CASSAGNE, Juan Carlos. Derecho Administrativo II. 6a ed. Buenos Aires: Abeledo-Perrot, 2000, p. 146 (tradução livre).

161 JUAN LIMA, Fernando E. el silencio Administrativo: Problemas Actuales. Revista Eletrônica de Direito do Estado - ReDE nº7/2006, Instituto de Direito Público da Bahia, Salvador, p. 4. Disponível na Internet: http://www.direitodoestado.com.br . Acesso em 15 de outubro de 2007. (tradução livre)
} 
dias. Vencido o prazo que corresponda, o interessado requererá pronto despacho e, se transcorrerem outros dias sem se produzir dita resolução, considerar-se-á que há silêncio da Administração.

Rafael Bielsa sustenta que, de uma maneira geral, à Administração aplicam-se as seguintes regras: a) quando a Administração pública não decide, ao final de um prazo assinalado, deve entender-se, salvo prova em contrário, que há uma transgressão que pode gerar responsabilidade para a Administração, bem como direito de indenização, se a omissão gerar dano; se inexiste um termo assinalado, a Administração não incorre em responsabilidade, e seu silêncio pode gerar outras conseqüências; b) quando se pede uma decisão do administrador e esta não é pronunciada ou a autoridade não pratica o ato vinculado, entende-se que a petição não foi admitida, ou a autorização ou aprovação pedida foi negada; c) o silêncio não pode entender-se como acolhimento ou rejeição em relação aos atos submetidos a sua aprovação se não houver uma disposição nesse sentido ou se não houver outra resolução que pressuponha de maneira certa a vontade de aprovar ou rechaçar o pedido de autorização ${ }^{162}$.

\section{Como ensina Rafael Bielsa,}

A aprovação tácita é de interpretação restritiva, e sustentamos que seja assim: $1^{\circ}$ Porque toda decisão que compromete a autoridade ou a responsabilidade da Administração pública ou se vincula a um ato essencial da atividade administrativa, deve ser dada expressamente e, em bom princípio, também deve ser fundamentada; $2^{\circ}$ Porque a aprovação tácita como regra, viria a legitimar a inércia ou negligência administrativas, criando atos que, além de inconvenientes ou ilegais, não comprometeriam o funcionário ou os funcionários que nele houvessem intervindo. Por fim, isto permitira o oportunismo à custa da Administração pública ${ }^{163}$.

O autor sugere três princípios para nortear a interpretação do silêncio da Administração. Em primeiro lugar, quando se cuidar de trâmites necessários, como, por exemplo, reclamações administrativas, entende-se que falta de pronunciamento ao fim do prazo legal importa rejeição do pedido. A segunda regra, aplicável quando a reclamação está sujeita a um termo ou condição, deve-se entender que, ocorrido o primeiro ou implementada a segunda sem manifestação da Administração, a decisão é negativa e, via

${ }^{162}$ BIELSA, Rafael. Principios de Derecho Administrativo. $3^{\mathrm{a}}$ ed. Buenos Aires: Universidad Nacional Del Litoral - Santa Fe, 1942, p. 67(tradução livre).

${ }^{163}$ BIELSA, Rafael. Principios de Derecho Administrativo. $3^{\mathrm{a}}$ ed. Buenos Aires: Universidad Nacional Del Litoral - Santa Fe, 1942, p. 68 (tradução livre). 
de conseqüência, podem ser exercitados os recursos jurisdicionais respectivos. Por fim, no que toca aos contratos administrativos, devem ser observadas as seguintes regras, na ordem em que seguem: primeiro, as cláusulas da convenção; segundo, as regras de Direito Público (ius imperii); terceiro, o artigo 1.146 do Código Civil, que cuida do consentimento tácito, a depender da natureza do contrato. Rafael Bielsa conclui: "En opinión nuestra esta disposición, sin embargo, no es aplicable tal como se interpreta el Código Civil"164.

É importante distinguir, no Direito argentino, o silêncio positivo dos atos tácitos, que não se confundem. Estes, ao contrário do silêncio, pressupõem um ato expresso, cujos efeitos fazem concluir ter havido um outro, tácito. Como explica Juan Carlos Cassagne:

Tal ocorreria - por exemplo - se logo após haver-se aludido ao procedimento da licitação pública, a Administração, mediante decisão legalmente fundamentada, deliberar a contratação direta. Em tal hipótese, haveria que considerar, como o fez a Procuradoria do Tesouro da Nação, que a decisão de contratar de outra forma leva implícita a de tornar sem efeito o chamamento à licitação ${ }^{165}$.

Importante salientar que, para mais de um privilégio da Administração, o silêncio é visto como regra estabelecida em favor dos administrados. Fernando E. Juan Lima escreve:

Sem entrar em digressões terminológicas, é necessário deixar assentado que o silêncio vem a constituir uma resposta da Administração que a lei presume em determinadas circunstâncias diante da petição deduzida por um interessado e que não é senão a contrapartida indispensável do direito de petição.

O silêncio se estabeleceu em benefício do particular, e não apenas o silêncio positivo, em que isto é evidente, já que a petição resulta deferida, mas também o negativo, pois deste modo se impede a restrição da defesa do particular, impossibilitando-se que a Administração inutilize toda a via revisora ulterior, por descumprir o dever de decidir diante da petição do interessado que pretende obter uma resposta. ${ }^{166}$

$\mathrm{O}$ autor ainda escreve que, para que se configure o silêncio administrativo no Direito argentino, há duas formas: a) ou o administrado deve denunciar a mora

${ }^{164}$ BIELSA, Rafael. Principios de Derecho Administrativo. $3^{\mathrm{a}}$ ed. Buenos Aires : Universidad Nacional Del Litoral - Santa Fe, 1942, p. 68 (tradução livre).

${ }^{165}$ CASSAGNE, Juan Carlos. Derecho Administrativo II. 6a ed. Buenos Aires: Abeledo-Perrot, 2000, p. 147 (tradução livre).

${ }^{166}$ JUAN LIMA, Fernando E. el silencio Administrativo: Problemas Actuales. Revista Eletrônica de Direito do Estado - ReDE no7/2006, Instituto de Direito Público da Bahia, Salvador, pp. 3/4. Disponível na Internet: http://www.direitodoestado.com.br . Acesso em 15 de outubro de 2007. (tradução livre) 
administrativa, o que acontece nos casos de petição ou reclamação, superado o prazo de trinta dias, na regra do artigo 10 da LNPA, ou quarenta e cinco dias, em se tratando da via reclamatória; b) ou o silêncio opera-se, automaticamente, sem necessidade de nenhuma providência por parte do interessado, o que tem lugar nas hipóteses de recurso administrativo, quando extrapolado o prazo para decisão. Essas regras são as previstas pela legislação nacional, pois a legislação provincial, por sua vez, é muito heterogênea ${ }^{167}$.

167167 JUAN LIMA, Fernando E. el silencio Administrativo: Problemas Actuales. Revista Eletrônica de Direito do Estado - ReDE n07/2006, Instituto de Direito Público da Bahia, Salvador, p. 5. Disponível na Internet: http://www.direitodoestado.com.br . Acesso em 15 de outubro de 2007. (tradução livre) 


\subsection{O silêncio administrativo no Direito brasileiro}

Não existe uma lei nacional que trate, genericamente, do silêncio administrativo, cominando conseqüências, positivas ou negativas, à inércia da Administração. O que há, apenas, são leis esparsas sobre o assunto.

A Lei de Processo Administrativo Federal ( $n^{\circ 9.894 / 99)}$ estabelece que, à míngua de disposição específica, os atos a serem praticados, pelos agentes da Administração ou pelos administrados, no curso do processo administrativo, devem atender ao prazo de cinco dias, prorrogável por mais cinco mediante "comprovada justificação" (art. 24). Também estabelece:

Art. 49. Concluída a instrução de processo administrativo, a Administração tem o prazo de até 30 (trinta) dias para decidir, salvo prorrogação por igual período expressamente motivada.

A lei não prevê, contudo, a conseqüência da inação administrativa. Ao contrário, condena o silêncio administrativo, ao dispor: "A Administração tem o dever de explicitamente emitir decisão nos processos administrativos e sobre solicitações ou reclamações, em matéria de sua competência" (art. 48).

A princípio, ao menos para a Administração Pública Federal, o silêncio é, portanto, a infração de um dever (o dever de decidir explícita e motivadamente) e, conseqüentemente, um ilícito.

Daí porque Cláudio Brandão escreve que "o silêncio administrativo consiste na violação ao dever de decidir que se impõe à Administração Pública como princípio"

${ }^{168}$ BRANDÃO, Cláudio. In OSÓRIO, Fábio Medina,e SOUTO, Marcos Juruena Villela (coordenadores). Direito Administrativo. Estudos em homenagem a Diogo de Figueiredo Moreira Neto. Rio de Janeiro: Lumen Juris, 2006, p. 7. 


\subsubsection{O silêncio administrativo na legislação brasileira}

A lei do processo administrativo do Estado de São Paulo (Lei 10.177/98) atribui, como regra, o caráter negativo ao silêncio da Administração, nos seguintes termos:

Artigo 33 - O prazo máximo para decisão de requerimentos de qualquer espécie apresentados à Administração será de 120 (cento e vinte) dias, se outro não for legalmente estabelecido.

$\S 1^{\circ}$ - Ultrapassado o prazo sem decisão, o interessado poderá considerar rejeitado o requerimento na esfera administrativa, salvo previsão legal ou regulamentar em contrário.

$\S 2^{\circ}$ - Quando a complexidade da questão envolvida não permitir o atendimento do prazo previsto neste artigo, a autoridade cientificará o interessado das providências até então tomadas, sem prejuízo do disposto no parágrafo anterior.

$\S 3^{\circ}$ - O disposto no $\S 1^{\circ}$ deste artigo não desonera a autoridade do dever de apreciar o requerimento.

Cuida-se de legislação interessante, pois estabelece um prazo razoável para a Administração manifestar-se, permitindo, ainda, seja este dilatado, a depender da complexidade da questão envolvida.

A Lei 9.507/07, que trata do processo de Habeas Data, estabelece mais uma hipótese de silêncio negativo. Após definir que o Habeas Data será concedido "para assegurar o conhecimento de informações relativas à pessoa do impetrante, constantes de registro ou banco de dados de entidades governamentais ou de caráter público" (art. $\left.7^{\circ}, \mathrm{I}\right)$, "para a retificação de dados, quando não se prefira fazê-lo por processo sigiloso, judicial ou administrativo" (art. $7^{\circ}$, II) e "para a anotação nos assentamentos do interessado, de contestação ou explicação sobre dado verdadeiro mas justificável e que esteja sob pendência judicial ou amigável" (art. $7^{\circ}$, III), a lei estabelece quais provas devem instruir a petição inicial. E arrola, como uma das provas exigíveis a "da recusa ao acesso às informações ou do decurso de mais de 10 (dez) dias sem decisão" (art. 8, parágrafo único, I).

Isto é, escoado o prazo, legalmente estabelecido, sem que a Administração forneça as informações cujo conhecimento é assegurado aos administrados, caracteriza-se a recusa 
do Poder Público, estando o postulante habilitado a ingressar em juízo com o Habeas Data (isto é, tendo interesse jurídico para tanto).

A lei que trata da súmula vinculante, a Lei nº11.417/2006, cuidou, também, da omissão da Administração. Eis a redação legal:

\begin{abstract}
Art. $7^{\circ}$ Da decisão judicial ou do ato administrativo que contrariar enunciado de súmula vinculante, negar-lhe vigência ou aplicá-lo indevidamente caberá reclamação ao Supremo Tribunal Federal, sem prejuízo dos recursos ou outros meios admissíveis de impugnação.

$\S 1^{\circ}$ Contra omissão ou ato da administração pública, o uso da reclamação só será admitido após esgotamento das vias administrativas.

$\$ 2^{\circ}$ Ao julgar procedente a reclamação, o Supremo Tribunal Federal anulará o ato administrativo ou cassará a decisão judicial impugnada, determinando que outra seja proferida com ou sem aplicação da súmula, conforme o caso.
\end{abstract}

O legislador não foi claro quanto à consequiência da omissão contrária à súmula. Deixou claro que esta, tal qual o ato comissivo, pode dar ensejo à reclamação. Mas é evidente que, quando se trata de inação, não se pode cogitar de anulação do ato, justamente porque não há ato.

José dos Santos Carvalho Filho sustenta:

Como não há propriamente anulação de conduta omissiva, nem pode o Judiciário suprir-lhe a ausência em virtude do princípio da separação de funções, o STF, no caso de procedência da reclamação, só poderá determinar ao administrador o cumprimento de atuação comissiva (facere), proferindo, destarte, decisão de caráter mandamental (ou condenatório determinativo, como preferem alguns processualistas) ${ }^{169}$.

Ademais, o legislador não esclareceu qual o prazo que deve o administrado aguardar até que se caracterize a omissão administrativa. É certo que a Lei $n^{\circ}$ 9.784/99 previu um prazo para a Administração proferir decisão no processo administrativo. Todavia, é preciso ter presente que este prazo só se aplica, em princípio, à Administração Pública Federal, enquanto que qualquer dos entes federativos pode se omitir contrariamente a súmula vinculante do Supremo Tribunal Federal.

\footnotetext{
${ }^{169}$ CARVALHO FILHO, José dos Santos. Manual de Direito Administrativo. $18^{\mathrm{a}}$ ed. Rio de Janeiro: Lumen Iuris, 2007, p. 96.
} 
Como o legislador exigiu, expressamente, o esgotamento das instâncias administrativas, deveria ter previsto o prazo para manifestação do administrador, criando, assim, hipótese legal de silêncio administrativo. Não o tendo feito, a questão referente ao prazo permanece subjetiva. O próprio Supremo Tribunal Federal poderá negar-se a conhecer da reclamação, sob o argumento de que as vias administrativas não foram, ainda, esgotadas.

Sem dúvida, tratar a lei expressamente da omissão foi um avanço na legislação brasileira. Mas o legislador poderia ter solucionado melhor o problema, impondo prazo à Administração e esclarecendo o que o Tribunal pode fazer diante da omissão contrária a súmula vinculante.

Há, ainda, vários casos de silêncio previstos pelas legislações municipais e estaduais. Cite-se um exemplo de silêncio positivo previsto pela Lei 13.525, de 28 de fevereiro de 2003, do Município de São Paulo. A lei em questão tratava da instalação de painéis publicitários em via pública - atividade depois totalmente proibida pela Lei cidade Limpa. Dispunha o diploma mencionado:

Art. 59 - O Poder Público Municipal deverá observar os seguintes prazos na tramitação dos pedidos de autorização:

I - 30 (trinta) dias para deferir ou indeferir o pedido de autorização para anúncio simples, contados a partir da data do seu protocolamento;

II - 45 (quarenta e cinco) dias para expedir o Alvará de Instalação de Anúncio ou indeferir o pedido de autorização para anúncio complexo ou especial, contados a partir da data do seu protocolamento;

III - 30 (trinta) dias para deferir ou indeferir o pedido de autorização para anúncio complexo ou especial, contados a partir da data em que o interessado comunicar a instalação do anúncio de acordo com o Alvará de Instalação expedido, nos termos do artigo 55.

$\S 1^{\circ}$ - O curso dos prazos previstos neste artigo ficará suspenso durante a pendência do atendimento, pelo interessado, de exigências feitas em "comunique-se".

$\S 2^{\circ}$ - Decorridos os prazos estabelecidos nos incisos I e II deste artigo, o interessado deverá comunicar o órgão competente e, após 15 (quinze) dias desta comunicação, não havendo o indeferimento do pedido, poderá instalar o anúncio. 
$\S 3^{\circ}$ - A instalação prevista no parágrafo anterior não exime o interessado de atender a todas as disposições desta lei e recolher, de imediato, a Taxa de Fiscalização de Anúncios - TFA.

$\S 4^{\circ}$ - Na situação prevista no artigo 59 o interessado fica isento das sanções previstas pela exibição de anúncio sem a devida licença ou Alvará de Instalação.

Cuidava-se, pois, de nítida hipótese de silêncio positivo: formalizando o interessado um pedido de autorização para instalação do anúncio e não recebendo resposta nos prazos previstos em lei, estava, tacitamente, autorizada a instalação, e o administrado não poderia ser autuado pela falta de alvará.

Interessante observar, contudo, que o interessado poderia ser autuado por outros motivos - por exemplo, por não ter recolhido a taxa devida ou por instalar o anúncio em desconformidade com a lei, no que toca às dimensões ou à localização do anúncio. Vale dizer que haveria uma autorização tácita, mas o administrado assumiria o ônus de verificar se as condições legais para a instalação do anúncio foram adimplidas. Se estivessem todas as características em conformidade com a lei, exceto pela falta de autorização (expressa), o particular não poderia ser autuado, pois seria titular de autorização tácita.

É muito comum, também, a previsão de hipóteses de silêncio positivo nos Códigos de Obras Municipais. O Código de Obras do Município de São Paulo, instituído pela Lei 11.228/92, prevê:

\section{2 - PRAZOS PARA DESPACHO}

O prazo para despacho não poderá exceder a 90 (noventa) dias, inclusive nos pedidos relativos a reconsideração de despacho ou recurso.

4.2.1 - O curso desse prazo ficará suspenso durante a pendência do atendimento, pelo requerente, de exigências feitas em "comunique-se".

4.2.2 - Prazos menores poderão ser fixados por ato do Executivo.

4.2.3 - Escoado o prazo para decisão de processo de Alvará de Aprovação, poderá ser requerido Alvará de Execução. Decorridos 30 (trinta) dias deste requerimento, sem decisão no processo de Alvará de Aprovação, a obra poderá ser iniciada, sendo de inteira responsabilidade do proprietário e profissionais envolvidos a eventual adequação da obra às posturas municipais. 
4.2.4 - Escoado o prazo para decisão do processo relativo a emissão de Certificado de Conclusão, a obra poderá ser utilizada a título precário, não se responsabilizando a PMSP por qualquer evento decorrente de falta de segurança ou salubridade.

Cuida-se de hipótese de silêncio positivo. Em regra, nenhuma obra pode ser iniciada sem a prévia obtenção de alvará de execução. Passado o prazo legal, todavia, a obra pode ser iniciada - mas as demais normas municipais concernentes à edificação devem, evidentemente, ser obedecidas, sob pena de serem responsabilizados o proprietário e os responsáveis técnicos.

As hipóteses mais comuns de silêncio positivo, como se vê, são referentes a atos vinculados retardados pela Administração. Cuida-se, normalmente, de casos de concessões licenças, a que o particular, adimplidas determinadas condições de lei, teria direito. E cuida-se, em regra, de situações corriqueiras, em relação às quais a previsão de um silêncio positivo pode ajudar a Administração, à medida que a exime de ter de manifestar-se, expressa e motivadamente, em todos os casos. Desta forma, ela pode deixar para se manifestar apenas nos casos em que o postulante não preencha as condições necessárias.

Há casos, porém, em que, não obstante a importância e o impacto da decisão omitida (ou retardada), prevê-se uma consequiência para o silêncio da Administração. Uma hipótese de silêncio positivo prevista em legislação federal é a presente na Lei 8.884/94, que cuida das infrações contra a ordem econômica. Dispõe o artigo 54 desta lei:

Art. 54. Os atos, sob qualquer forma manifestados, que possam limitar ou de qualquer forma prejudicar a livre concorrência, ou resultar na dominação de mercados relevantes de bens ou serviços, deverão ser submetidos à apreciação do Cade.

$\S 1^{\circ} \mathrm{O}$ Cade poderá autorizar os atos a que se refere o caput, desde que atendam as seguintes condições:

I - tenham por objetivo, cumulada ou alternativamente:

a) aumentar a produtividade;

b) melhorar a qualidade de bens ou serviço; ou

c) propiciar a eficiência e o desenvolvimento tecnológico ou econômico;

II - os benefícios decorrentes sejam distribuídos eqüitativamente entre os seus participantes, de um lado, e os consumidores ou usuários finais, de outro; 
III - não impliquem eliminação da concorrência de parte substancial de mercado relevante de bens e serviços;

IV - sejam observados os limites estritamente necessários para atingir os objetivos visados.

$\S 2^{\circ}$ Também poderão ser considerados legítimos os atos previstos neste artigo, desde que atendidas pelo menos três das condições previstas nos incisos do parágrafo anterior, quando necessários por motivo preponderantes da economia nacional e do bem comum, e desde que não impliquem prejuízo ao consumidor ou usuário final.

$\S 3^{\circ}$ Incluem-se nos atos de que trata o caput aqueles que visem a qualquer forma de concentração econômica, seja através de fusão ou incorporação de empresas, constituição de sociedade para exercer o controle de empresas ou qualquer forma de agrupamento societário, que implique participação de empresa ou grupo de empresas resultante em vinte por cento de um mercado relevante, ou em que qualquer dos participantes tenha registrado faturamento bruto anual no último balanço equivalente a $\mathrm{R} \$ 400.000 .000,00$ (quatrocentos milhões de reais). (Redação dada pela Lei $\mathrm{n}^{\circ} 10.149$, de 21.12.2000)

$\S 4^{\circ}$ Os atos de que trata o caput deverão ser apresentados para exame, previamente ou no prazo máximo de quinze dias úteis de sua realização, mediante encaminhamento da respectiva documentação em três vias à SDE, que imediatamente enviará uma via ao Cade e outra à Seae. (Redação dada pela Lei n ${ }^{\circ}$ 9.021, de 30.3.95)

$\S 5^{\circ}$ A inobservância dos prazos de apresentação previstos no parágrafo anterior será punida com multa pecuniária, de valor não inferior a 60.000 (sessenta mil) Ufir nem superior a 6.000 .000 (seis milhões) de Ufir a ser aplicada pelo Cade, sem prejuízo da abertura de processo administrativo, nos termos do art. 32 .

$\S 6^{\circ}$ Após receber o parecer técnico da Seae, que será emitido em até trinta dias, a SDE manifestar-se-á em igual prazo, e em seguida encaminhará o processo devidamente instruído ao Plenário do Cade, que deliberará no prazo de sessenta dias. (Redação dada pela Lei $\mathrm{n}^{\circ}$ 9.021, de 30.3.95)

$\S 7^{\circ}$ A eficácia dos atos de que trata este artigo condiciona-se à sua aprovação, caso em que retroagirá à data de sua realização; não tendo sido apreciados pelo Cade no prazo estabelecido no parágrafo anterior, serão automaticamente considerados aprovados. (Redação dada pela Lei $\mathrm{n}^{\mathrm{o}}$ 9.021, de 30.3.95)

$\S 8^{\circ}$ Os prazos estabelecidos nos $\S \S 6^{\circ}$ e $7^{\circ}$ ficarão suspensos enquanto não forem apresentados esclarecimentos e documentos imprescindíveis à análise do processo, solicitados pelo Cade, SDE ou SPE.

$\S 9^{\circ} \mathrm{Se}$ os atos especificados neste artigo não forem realizados sob condição suspensiva ou deles já tiverem decorrido efeitos perante terceiros, inclusive de natureza fiscal, o Plenário do Cade, se concluir 
pela sua não aprovação, determinará as providências cabíveis no sentido de que sejam desconstituídos, total ou parcialmente, seja através de distrato, cisão de sociedade, venda de ativos, cessação parcial de atividades ou qualquer outro ato ou providência que elimine os efeitos nocivos à ordem econômica, independentemente da responsabilidade civil por perdas e danos eventualmente causados a terceiros.

$\S 10$. As mudanças de controle acionário de companhias abertas e os registros de fusão, sem prejuízo da obrigação das partes envolvidas, devem ser comunicados à SDE, pela Comissão de Valores Mobiliários (CVM) e pelo Departamento Nacional de Registro Comercial do Ministério da Indústria, Comércio e Turismo (DNRC/MICT), respectivamente, no prazo de cinco dias úteis para, se for o caso, serem examinados.

Ora, o parágrafo $7^{\circ}$ do artigo traz, indubitavelmente, uma previsão de silêncio positivo: deixando o CADE de exprimir-se por mais de sessenta dias, considera-se autorizado o ato que se pretende praticar. Dada a importância das questões submetidas à apreciação dessa autarquia e, ainda, o caráter especializadíssimo de que se revestem suas manifestações, não parece de boa técnica, neste caso, a previsão de uma conseqüência para a mora administrativa - menos ainda uma conseqüência positiva, concessiva. Melhor seria a mera previsão do prazo, permitindo ao interessado acessar o Judiciário e requerer a manifestação expressa. De fato, considerar-se tacitamente autorizado um ato, potencialmente danoso à ordem econômica, parece por demais arriscado. 


\subsubsection{O silêncio administrativo na jurisprudência brasileira}

Talvez uma das mais antigas manifestações jurisprudenciais sobre o silêncio da Administração seja a Súmula 429 do Supremo Tribunal Federal, cuja redação é a seguinte: "A existência de recurso administrativo com efeito suspensivo não impede o uso do mandado de segurança contra omissão da autoridade". A regra cuidou de beneficiar o particular quando ocorresse o que no Direito italiano se convencionou chamar "silêncio sobre recurso hierárquico". Não se trata de um silêncio puro, pois pressupõe uma ofensa a direito do particular contra a qual este se insurge na via recursal administrativa. A idéia é que, mesmo que não haja prazo para a Administração manifestar-se, o particular não pode ter seu acesso ao Poder Judiciário obstado.

Não é fácil, de modo geral, encontrar referências expressas ao silêncio da administração nos julgados nacionais - até pelo fato de a matéria não merecer tratamento especial da nossa legislação.

O Superior Tribunal de Justiça tem interessante decisão, bastante recente, acerca do tema do silêncio administrativo. Cuida-se de hipótese em que se pretendia a aplicação do artigo 38 do Código Brasileiro de Telecomunicações (Lei 4.117/62), cuja redação original era a seguinte:

Art. 38. Nas concessões e autorizações para a execução de serviços de radiodifusão serão observados, além de outros requisitos, os seguintes preceitos e cláusulas:

a) os diretores e gerentes serão brasileiros natos e os técnicos encarregados da operação dos equipamentos transmissores serão brasileiros ou estrangeiros com residência exclusiva no País permitida, porém, em caráter excepcional e com autorização expressa do Conselho de Telecomunicações, a admissão de especialistas estrangeiros, mediante contrato, para estas últimas funções.

b) a modificação dos estatutos e atos constitutivos das emprêsas depende, para sua validade, de aprovação do Govêrno, ouvido prèviamente o Conselho Nacional de Telecomunicações;

c) a transferência da concessão, a cessão de cotas ou de ações representativas do capital social, dependem, para sua validade, de autorização do Govêrno após o pronunciamento do Conselho Nacional de 
Telecomunicações.

(VETADO).

O silêncio do Poder concedente ao fim de 90 (noventa) dias contados da data da entrega do requerimento de transferência de ações ou cotas, implicará na autorização.

Tratando-se de questão de relevante interesse nacional, o Superior Tribunal de Justiça negou aplicação ao último parágrafo do mencionado artigo, tendo assim decidido:

ADMINISTRATIVO. RECURSO ESPECIAL. CONCESSÃO DE SERVIÇOS PÚBLICOS DE RADIODIFUSÃO. TRANSFERÊNCIA DE COTAS. ALTERAÇÃO NA GERÊNCIA. OMISSÃO DO PODER PÚBLICO. IMPOSSIBILIDADE DE AUTORIZAÇÃO TÁCITA EM RAZÃO DE MUDANÇAS NA ADMINISTRAÇÃO DA SOCIEDADE. LEI 4.117/62 E DECRETO 52.795/63.

1. Por se tratar de atividade estratégica aos interesses nacionais, a exploração dos serviços de radiodifusão, exercida mediante concessão do Poder Público, é objeto de especiais controle e fiscalização pelo Estado, inclusive e principalmente, em relação às pessoas que exercem o comando econômico e gerencial das empresas concessionárias.

2. Licença-tácita e autorização-tácita configuram anomalia no quadro jurídico do Estado Social, instaurado pela Constituição Federal de 1988, pois implicariam delegação ou privatização indireta do poder de polícia, monopólio estatal.

3. Nesse sentido, a autorização tácita da transferência de cotas de sociedades concessionárias de serviços de radiodifusão, prevista na redação original do art. 38, parágrafo final, da Lei 4.117/62, deve ser interpretada cum grano salis.

4. No presente caso, verificando-se que as mudanças promovidas na sociedade concessionária importavam alteração em seu controle e gerência, impossível afastar a exigência de autorização expressa por parte do poder concedente.

5. Recurso Especial a que se nega provimento.

(STJ - 2a turma - Relator Min. Herman Benjamin - RESP 636302/DF j. em 26/09/2006 - RT 866/133) 


\section{O CONTROLE DO SILÊNCIO ADMINISTRATIVO PELO PODER JUDICIÁRIO}

\subsection{Introdução}

Como visto no capítulo anterior, a maioria dos sistemas jurídicos da Europa Ocidental preocupou-se em regular o silêncio administrativo, de modo a torná-lo juridicamente relevante, como dizem os italianos, ou de forma a caracterizar atos presumidos (como são chamados na Espanha) ou tácitos (conforme se diz em Portugal). A terminologia muda de país a país, assim como variam os prazos ou a forma de caracterização do silêncio. O objetivo, porém, é o mesmo: dar ao particular instrumentos para ingressar em juízo contra uma inércia que lhe seja prejudicial. Em muitos casos, mormente em se tratando de silêncio positivo, a legislação sobre o tema visa, também, a agilizar a atividade administrativa, tornando prescindível, em determinadas hipóteses, a expedição de decisão expressa e motivada.

Nossa Constituição Federal estabelece, como uma das garantias fundamentais dos cidadãos, que "a lei não excluirá da apreciação do Poder Judiciário lesão ou ameaça a direito" (art. $5^{\circ}, \mathrm{XXXV).} \mathrm{Poder-se-ia,} \mathrm{então,} \mathrm{imaginar} \mathrm{que} \mathrm{a} \mathrm{questão} \mathrm{do} \mathrm{silêncio} \mathrm{constitui,}$ no Brasil, um falso problema, pois não haveria a exigência de um ato administrativo como condição para o ingresso em juízo.

Todavia, a doutrina da teoria do silêncio parece de sobrelevada importância quando se tem em mente que, para que uma ação seja julgada pelo mérito, devem estar presentes as condições da ação. E, em princípio, na ausência de um ato administrativo lesivo a direito seu, o administrado carece de interesse jurídico, na modalidade necessidade. Tampouco há pretensão resistida.

Deve-se ter presente que, como afirmam Nelson Nery Junior e Rosa Maria Andrade Nery, 
A necessidade de serem preenchidas as condições da ação (CPC 267 VI) e os pressupostos processuais (CPC 267 IV), serem observados os prazos para o exercício do direito de ação, bem como serem obedecidas as formas dos atos processuais significam limitações naturais e legítimas ao exercício do direito de ação ${ }^{170}$.

Isto é, discutir se a exigência da prática de um ato administrativo ou se a caracterização da omissão administrativa como juridicamente relevante (ou emprestar-lhe a lei status de ato tácito, presumido) estão compreendidas no âmbito das condições da ação não é, de forma alguma, negar vigência ao princípio do acesso à justiça.

Com efeito, se o administrador não denega a pretensão do administrado, não há nem resistência, nem conflito de interesses. Se o administrado não formula sua pretensão perante a Administração ou não aguarda um tempo razoável para que esta se pronuncie sobre seu pleito, não parece haver interesse jurídico que justifique o acesso ao Poder Judiciário.

De outro lado, pretender que o administrado espere por três anos pela solução de uma questão simples também foge à razoabilidade.

É importante que se discuta, portanto, a partir de que momento o silêncio da Administração representa uma ofensa ao interesse do particular, permitindo-lhe socorrer-se do Poder Judiciário.

\footnotetext{
${ }^{170}$ NERY JUNIOR, Nelson, e NERY, Rosa Maria Andrade. Código de Processo Civil Comentado. $2^{\text {a }}$ ed. São Paulo: RT, 1996, p. 137.
} 


\subsection{O princípio do acesso à justiça}

Para que se afirme que a caracterização do silêncio administrativo pode ser exigida pelo Poder Judiciário como condição para o julgamento do mérito da causa sem que se configure ofensa ao princípio do acesso à justiça, é preciso compreender a extensão deste.

$\mathrm{O}$ inciso XXXV do artigo $5^{\circ}$ da Constituição Federal estabelece que "a lei não excluirá da apreciação do Poder Judiciário lesão ou ameaça a direito".

Essa garantia aparece expressa, pela primeira vez, na Constituição Federal de 1946, que previa, em seu artigo 141, parágrafo segundo: “A lei não poderá excluir da apreciação do Poder Judiciário qualquer lesão a direito individual".

Desde então, a fórmula vem sendo repetida: na Constituição de 1967 (art. 150, $\S^{\circ}$ ), e na Emenda Constitucional n01/69, com redação dada pela Emenda Constitucional nº7/77 (art. 153, $\left.4^{\circ}\right)$. Interessante observar que esta última previa um prazo para ser proferida a decisão administrativa. Eis a redação do parágrafo quarto do artigo 153,:

$\S 4^{\circ}$. A lei não poderá excluir da apreciação do Poder Judiciário qualquer lesão de direito individual. O ingresso em juízo poderá ser condicionado a que se exauram previamente as vias administrativas, desde que não exigida garantia de instância, nem ultrapassado o prazo de cento e oitenta dias para decisão sobre o pedido.

A previsão não deixava de ser uma regra geral sobre o silêncio administrativo: o administrado poderia ser compelido a remeter seu pedido às vias administrativas; quedando-se inerte a Administração por período superior a cento e oitenta dias, contudo, o silêncio se tornaria juridicamente relevante (emprestando-se expressão do Direito italiano), permitindo-se ao postulante o acesso ao Judiciário.

A exigência de prévio acesso às instâncias administrativas não foi repetida pela Constituição de 1988. Escreve Alexandre de Moraes: 
Inexiste a obrigatoriedade de esgotamento da instância administrativa para que a parte possa acessar o Judiciário. A Constituição Federal de 1988, diferentemente da anterior, afastou a necessidade da chamada jurisdição condicionada ou instância administrativa de curso forçado, pois já se decidiu pela inexigibilidade de exaurimento das vias administrativas para obter-se o provimento judicial, uma vez que excluiu a permissão, que a Emenda Constitucional $\mathrm{n}^{\circ} 7$ à Constituição anterior estabelecera, de que a lei condicionasse o ingresso em juízo à exaustão das vias administrativas, verdadeiro obstáculo ao princípio do livre acesso ao Poder Judiciário ${ }^{171}$.

É preciso ter presente, porém, que a desnecessidade de exaurimento das vias administrativas não implica que o administrado não tenha que comprovar seu interesse de agir, vale dizer, a negativa da Administração em atendê-lo, ou o prejuízo que esta lhe causou.

Celso Ribeiro Bastos refere que o princípio da ampla acessibilidade ao Poder Judiciário é uma decorrência lógica do princípio da tripartição dos Poderes, por se tratar de um dos sustentáculos do Estado de Direito. O autor explica que, da forma como a acessibilidade ao Poder Judiciário está tratada no nosso sistema constitucional, decorrem duas idéias:

Uma é de que toda lesão de direito, toda controvérsia, portanto, poderia ser levada ao Pode Judiciário e este teria de conhecê-la, respeitada a forma adequada de acesso a ele disposta pelas leis processuais civis.

A outra é a de que toda jurisdição, o que significa dizer, toda decisão definitiva sobre uma controvérsia jurídica, só poderia ser exercida pelo Poder Judiciário. Não haveria jurisdição fora deste, nem no Poder Executivo, nem no Poder Legislativo ${ }^{172}$.

\section{É preciso enfatizar a expressão "respeitada a forma adequada disposta pelas leis}

processuais civis”. Do princípio do amplo acesso ao Poder Judiciário não decorre o direito a um provimento de mérito, tout court. Há regras processuais a serem observadas. O que não se admite é que o acesso à via jurisdicional seja, desde logo, vedado, ou que se exija que o interessado esgote as vias administrativas. Mas o provimento de mérito depende do preenchimento das condições da ação, bem como da observância dos pressupostos processuais.

\footnotetext{
${ }^{171}$ MORAES, Alexandre de. Direito Constitucional. $8^{\text {a }}$ ed. São Paulo: Atlas, 2000, p. 98.

${ }^{172}$ BASTOS, Celso Ribeiro. Curso de Direito Constitucional. $18^{a}$ ed. São Paulo: Saraiva, 1997, p. 213.
} 
Comentando a redação do inciso XXXV do artigo $5^{\circ}$, Celso Ribeiro Bastos precisa:

Isto significa que lei alguma poderá auto-excluir-se da apreciação do Poder Judiciário quanto à sua constitucionalidade, nem poderá dizer que ela seja ininvocável pelos interessados perante o Poder Judiciário para resolução das controvérsias que surjam da sua aplicação ${ }^{173}$.

Ademais, o princípio do acesso à justiça envolve uma série de regras, que visam a garanti-lo, como, por exemplo, a concessão de assistência judiciária gratuita àqueles que não podem pagar as expensas do processo sem prejuízo de sua própria subsistência (Lei ${ }^{\circ}$ 1.060/50). Aliás, justamente, porque há uma série de condições técnicas a serem observadas é que se exige que as causas sejam patrocinadas sempre por advogados e que se garante às pessoas de baixa renda a defesa técnica em juízo.

Em suma, a Constituição visa a garantir que todos possam dirigir seus pleitos ao Poder Judiciário, independentemente de sua situação sócio-econômica e de contra quem litiguem. Mas há um conjunto de regras processuais a serem obedecidas. Dentre elas, encontra-se a exigência de interesse de agir para promover a demanda, sob pena de ser a ação extinta sem apreciação do mérito, na forma do artigo 267, IV, do Código de Processo Civil. Não se cuida, à evidência, de regra inconstitucional, à medida que visa, tão-somente, a regular a forma de acesso ao Poder Judiciário. Aliás, não houvesse regra alguma, o acesso à justiça restaria, irremediavelmente, comprometido, pois o Judiciário ver-se-ia à volta com um sem-número de processos, ações movidas sem nenhum fundamento, com pedidos impossíveis, contra partes ilegítimas ou sem pretensão resistida.

${ }^{173}$ BASTOS, Celso Ribeiro. Curso de Direito Constitucional. 18 a ed. São Paulo: Saraiva, 1997, p. 214. 


\subsection{A necessidade da caracterização do silêncio administrativo como interesse de agir}

No geral, espera-se que as leis sejam, espontaneamente, cumpridas. Espera-se que ninguém mate, que quem deve pague suas dívidas, que quem constrói uma edificação respeite as restrições administrativas e o direito de vizinhança etc. Exceto em poucos casos de jurisdição voluntária (que representam verdadeira atividade administrativa a cargo do Poder Judiciário), nos quais a lei exige o ingresso no Poder Judiciário para a tutela de determinado interesse - como acontece, por exemplo, nos casos de inventário e partilha quando há incapazes interessados (artigo 982 co Código de Processo Civil) e de divórcio consensual quando há filhos menores ou incapazes (artigo 1.124-A do Código de Rito) - o processo é um instrumento de pacificação social; vale dizer, é um meio pelo qual aquele que teve um direito seu lesado (ou que entende que o teve) pode obter a tutela de seu interesse.

Portanto, a ação deve ser um instrumento excepcional, apenas utilizável quando o esperado cumprimento espontâneo das leis não advier. Assim, por exemplo, se alguém tem direito a aposentar-se, deve pleitear a aposentadoria junto ao órgão previdenciário, não ajuizar uma ação para obtenção do benefício. Igualmente, quem tem um crédito deve esperar o decurso do prazo para pagamento, para apenas então, desejando, ajuizar a ação de cobrança; não pode, por achar que o devedor não terá condições de arcar com o pagamento, ajuizar, desde logo, a ação judicial.

Daí dizer-se que, na esfera cível, a ação é concebida, em princípio, para solucionar a lide (à exceção dos procedimentos de jurisdição voluntária, como mencionado). A lide é, comumente, definida como o conflito de interesses qualificado por uma pretensão resistida. Enquanto não há mora, verbi gratia, não se pode dizer que o devedor resistiu ao pagamento. E, enquanto não há resistência, não há interesse jurídico de agir.

Como explica Ovídio Araújo Baptista da Silva, 
O legítimo interesse de agir a que se refere o art. $3^{\circ}$ do Código de Processo Civil define-se como a necessidade que deve ter o titular do direito de servir-se do processo para obter a satisfação de seu interesse material, ou para, através dele, realizar o seu direito ${ }^{174}$.

Segundo já explicava Pontes de Miranda, "a necessidade, de que se trata, é a necessidade objetiva da tutela do juiz, sem ter de indagar se, no autor, havia ou há a necessidade subjetiva da propositura da ação"175.

Luiz Rodrigues Wambier, Flávio Renato Correia de Almeida e Eduardo Talamini escrevem:

$\mathrm{O}$ interesse processual está presente sempre que a parte tenha a necessidade de exercer o direito de ação (e, conseqüentemente, instaurar o processo para alcançar o resultado que pretende, relativamente à sua pretensão e, ainda mais, sempre que aquilo que se pede no processo (pedido) seja útil sob o aspecto prático. Essa necessidade tanto pode decorrer da imposição legal (separação judicial, p.ex.) quanto da negativa do réu em cumprir espontaneamente determinada obrigação ou permitir o alcance de determinado resultado (devedor que não paga o débito no vencimento ${ }^{176}$.

Ainda sobre o tema, escreve Celso Agrícola Barbi:

Segundo CHIOVENDA, "o interesse de agir consiste em que sem a intervenção dos órgãos jurisdicionais o autor sofreria um dano".

Nesta conceituação está, sem dúvida, a necessidade do uso dos meios jurisdicionais para a tutela de um direito.

Outros autores são mais liberais no conceituar o interesse de agir e o qualificam como a utilidade que se pode retirar da atividade jurisdicional. Digo mais liberais porque tudo que é necessário é útil, mas nem tudo que é útil é necessário.

A nosso ver, a primeira posição é a mais correta, porque o tempo e o trabalho dos órgãos jurisdicionais não devem ser gastos quando sua atividade não for necessária à proteção de um direito. Deve-se considerar que um dos problemas quase universais é o da morosidade dos serviços judiciais; e essa demora decorre geralmente do grande número de causas. Assim, para atendimento dos que realmente necessitam da proteção judicial deve-se afastar a pretensão dos que poderiam realizar seu direito sem intervenção daqueles órgãos ${ }^{177}$.

\footnotetext{
${ }^{174}$ BAPTISTA DA SILVA, Ovídio. Curso de Processo Civil. Vol. 1. $4^{\text {a }}$ ed. São Paulo: RT, 1998, p. 104.

175 MIRANDA, Pontes de. Comentários ao Código de Processo Civil. Tomo I. $2^{\mathrm{a}}$ ed. Rio de Janeiro: Forense, 1979, p. 169.

${ }^{176}$ WAMBIER, Luiz Rodrigues (coord.). Curso Avançado de Processo Civil. Vol. 1. 9a ed. São Paulo: RT, 2007, pp. 137-138.

${ }^{177}$ BARBI, Celso Agrícola. Comentários ao Código de Processo Civil. Vol. I. Tomo I. $1^{\text {a }}$ ed. Rio de Janeiro: Forense, 1975, p. 49.
} 
Enrico Tulio Liebman ensinava: "O interesse de agir surge da necessidade de obter do processo a proteção do interesse substancial; pressupõe, portanto, a lesão deste interesse e a idoneidade do provimento pedido para protegê-lo e satisfazê-lo"178.

Tendo isso em mente, parece bastante defensável a exigência da caracterização do silêncio como requisito para que Juiz profira uma sentença de mérito. O silêncio estaria para a decisão administrativa assim como a mora está para o pagamento. Aliás, a caracterização do silêncio não deixa de ser o reconhecimento de uma mora administrativa.

Se não dirige seu pedido à Administração, mas diretamente ao Poder Judiciário, falta ao administrado interesse de agir, na modalidade necessidade. Acionando, diretamente, o Poder Judiciário, o administrado subtrai à Administração a oportunidade de satisfazer seu interesse ou explicar por que não o faz.

Aliás, não existe nenhuma razão pela qual o atendimento das condições da ação não devesse ser exigido quando for ré a Fazenda Pública. Se a lei não obriga o administrado a exigir determinada providência pela via jurisdicional, o caminho natural é apresentar seu pedido à Administração.

O Supremo Tribunal Federal já expressou tal entendimento, ao julgar um recurso em Habeas Data. A ementa do julgamento é a que segue:

HABEAS DATA - NATUREZA JURÍDICA - REGIME DO PODER VISÍVEL COMO PRESSUPOSTO DA ORDEM DEMOCRÁTICA - A JURISDIÇÃO CONSTITUCIONAL DAS LIBERDADES - SERVIÇO NACIONAL DE INFORMAÇÕES (SNI) - ACESSO NǍ̃O RECUSADO AOS REGISTROS ESTATAIS - AUSÊNCIA DO INTERESSE DE AGIR - RECURSO IMPROVIDO.

A Carta Federal, ao proclamar os direitos e deveres individuais e coletivos, enunciou preceitos básicos, cuja compreensão é essencial a caracterização da ordem democrática como um regime do poder visível. O modelo político-jurídico, plasmado na nova ordem constitucional, rejeita o poder que oculta e o poder que se oculta. Com essa vedação, pretendeu o constituinte tornar efetivamente legítima, em face dos destinatários do poder, a prática das instituições do Estado.

$\mathrm{O}$ habeas data configura remédio jurídico-processual, de natureza constitucional, que se destina a garantir, em favor da pessoa interessada,

${ }^{178}$ LIEBMAN, Enrico Tulio. Manuale di Diritto Processuale Civile. I. $3^{\text {a }}$ ed. Milano: Giuffrè Editore, 1973, pp.121/122. (tradução livre) 
o exercício de pretensão jurídica discernível em seu tríplice aspecto: (a) direito de acesso aos registros; (b) direito de retificação dos registros e (c) direito de complementação dos registros.

Trata-se de relevante instrumento de ativação da jurisdição constitucional das liberdades, a qual representa, no plano institucional, a mais expressiva reação jurídica do Estado às situações que lesem, efetiva ou potencialmente, os direitos fundamentais da pessoa, quaisquer que sejam as dimensões em que estes se projetem.

O acesso ao habeas data pressupõe, dentre outras condições de admissibilidade, a existência do interesse de agir. Ausente o interesse legitimador da ação, torna-se inviável o exercício desse remédio constitucional.

A prova do anterior indeferimento do pedido de informação de dados pessoais, ou da omissão em atendê-lo, constitui requisito indispensável para que se concretize o interesse de agir no habeas data. Sem que se configure situação prévia de pretensão resistida, há carência da ação constitucional do habeas data.

(RHD 22/DF; Relator: Min. Marco Aurélio; Relator p/ Acórdão: Min. Celso de Mello; Julgamento: 19/09/1991; Órgão Julgador: Tribunal Pleno; Publicação DJ 01-09-1995, PP-27378)

A questão da comprovação da omissão como demonstração do interesse de agir liga-se, também, à questão da utilização do Mandado de Segurança como instrumento hábil a resguardar direito individual. Como lecionou Hely Lopes Meirelles,

equiparam-se a atos de autoridade as omissões administrativas das quais possa resultar lesão a direito subjetivo da parte, ensejando mandado de segurança para compelir a Administração a pronunciar-se sobre o requerido pelo impetrante e durante a inércia da autoridade pública não corre o prazo de decadência da impetração. ${ }^{179}$

Mas, ainda que se afirme a possibilidade de uma omissão lesar interesse legítimo do administrado, podendo ensejar a impetração de Mandado de Segurança, resta a questão da prova da omissão, mormente em se considerando que o Mandado de Segurança exige direito líquido e certo, isto é, prova pré-constituída dos fatos afirmados pelo impetrante.

Nos casos em que a legislação prevê um prazo para a Administração manifestar-se - caso das já mencionadas leis de processo administrativo federal e do Estado de São Paulo - a questão se resolve pelo decurso do tempo. Basta ao administrado comprovar que dirigiu seu pedido à Administração e que o prazo legal decorreu sem nenhuma manifestação desta.

${ }^{179}$ MEIRELLES, Hely Lopes. Mandado de Segurança, Ação Popular, Ação Civil Pública, Mandado de Injunção, 'Habeas Data'”. $21^{a}$ ed., atualizada por Arnoldo Wald, São Paulo: Malheiros, 1999, p. 32. 
Se não houver, porém, nenhum prazo previsto - isto é, se o pedido for dirigido a Administração estadual ou municipal cuja legislação não estabeleça, expressamente, um prazo para que esta responda ao pleito do administrado - caberá ao impetrante comprovar que endereçou seu pedido à Administração e que decorreu um prazo razoável sem manifestação, restando caracterizada, assim, a omissão administrativa. 


\subsection{Os limites ao controle do silêncio administrativo pelo Poder Judiciário}

Nas hipóteses em que a lei prevê o resultado do silêncio administrativo, seu controle pelo Poder Judiciário não parece oferecer maiores problemas. Quer tenha o silêncio força denegatória do pedido do administrado, quer implique o deferimento deste, o controle pelo Poder Judiciário opera de maneira idêntica ao controle dos atos administrativos em geral. Sendo assim, o juiz dará ao silêncio tratamento idêntico ao que dispensaria ao ato administrativo expresso, denegatório ou concessivo da pretensão ${ }^{180}$.

Com efeito, se a lei diz que, depois de um prazo determinado, considera-se o pedido deferido ou indeferido, a situação não difere da que existiria se a Administração houvesse decidido o pedido expressamente.

Ainda que a maior parte da doutrina negue ao silêncio caráter de ato administrativo, preferindo conceituá-lo como fato jurídico administrativo, nas hipóteses em que a lei pré-determina seus efeitos, não há, substancialmente, diferença, para fins de controle. Se o ato expresso teria um núcleo não sindicável pelo Judiciário, por relacionar-se ao exercício de poderes discricionários do administrador, igualmente o silêncio o terá. Se, de outro lado, $\mathrm{o}$ ato era totalmente regrado e, pois, integralmente passível de exame judicial, assim também o silêncio o será.

Como escreve Cláudio Brandão:

No indeferimento tácito, busca-se o controle judicial através do pedido de anulação do ato, como se houvesse manifestação expressa da Administração Pública. Assim, se tacitamente foi indeferida a pretensão a que o interessado tinha direito, compete ao Poder Judiciário, quando provocado, reconhecer a existência do direito violado, anular o ato tácito praticado e determinar que sejam adotadas as providências necessárias para sanar a lesividade.

Mesmo nos atos discricionários nos quais o silêncio administrativo significa indeferimento da pretensão do particular, o controle judicial em tese é possível quando for viável apurar, diante da situação concreta

\footnotetext{
${ }^{180}$ Neste caso, teria interesse de ingressar em juízo não aquele que formulou a pretensão e a teve atendida, que é, obviamente, carecedor da ação, mas terceiro, que tenha tido direito seu ofendido pela concessão tácita do pleito.
} 
ou de elementos colhidos durante a instrução processual, que houve uma redução da discricionariedade a zero e que só existe uma única solução que se mostra viável diante do interesse público.

O silêncio positivo não está imune do controle judicial. Os atos praticados por particulares, com base no deferimento tácito, têm como limite o ordenamento jurídico e podem ser controlados quando contrários à lei ou aos princípios de direito. $\mathrm{O}$ silêncio administrativo não produz efeito quando o particular não preencher os requisitos previstos na lei, sendo lógico deduzir que o deferimento tácito não alcança situações ilegais nas quais o particular não poderia exigir da Administração o atendimento da sua pretensão ${ }^{181}$.

Em suma, havendo previsão legal da conseqüência decorrente da inação administrativa, aplicam-se, ao deferimento ou indeferimento tácito, as mesmas regras observadas no controle jurisdicional do ato administrativo. Vale dizer que, em tais hipóteses, os aspectos formais são amplamente sindicáveis, enquanto que o núcleo do ato discricionário, isto é, os critérios de conveniência e oportunidade, não podem ser examinados pelo Poder Judiciário, salvo se se verificar, in casu, que houve desvio de poder etc. Tudo quanto foi dito no primeiro capítulo desta dissertação acerca do controle externo da Administração pelo Poder Judiciário aplica-se ao controle do silêncio da Administração.

Maior dificuldade reside nos casos em que a lei omite a consequiência do silêncio do administrador. Há, pois, uma dupla omissão: do administrador, que deixa de decidir, expressamente, o pleito do administrado, e do legislador, que deixa de prever uma conseqüência para este silêncio.

Se não há uma conseqüência legal para o silêncio administrativo, dois problemas se apresentam. O primeiro diz respeito à comprovação do interesse jurídico; o segundo, não menos importante, refere-se ao objeto da ação ou ao alcance do provimento jurisdicional.

Isso porque, conforme se expôs no primeiro capítulo deste trabalho, o Poder Judiciário não pode se substituir ao Executivo, fazendo escolhas que somente a este caberiam. Não pode, a pretexto de controlar a Administração, convolar-se em verdadeiro administrador. Tampouco pode se encolher, negando a tutela jurisdicional ao administrado

${ }^{181}$ BRANDÃO, Cláudio. In OSÓRIO, Fábio Medina, e SOUTO, Marcos Juruena Villela (coordenadores). Direito Administrativo - Estudos em Homenagem a Diogo Figueiredo Moreira Neto. Rio de Janeiro: Lumen Juris, 2006, pp. 14/15. 
em todo e qualquer caso em que haja omissão administrativa, deixando-o à mercê do administrador.

Escreve José dos Santos Carvalho Filho:

Caso não tenha êxito na via administrativa para obter manifestação comissiva da Administração, não restará para o interessado outra alternativa senão recorrer à via judicial. Diferentemente do que sucede na hipótese em que a lei indica que a omissão significa denegação - hipótese em que se pretende desconstituir relação jurídica -, o interessado deduzirá pedido de natureza mandamental (ou, para alguns, condenatória para cumprimento de obrigação de fazer), o qual, se for acolhido na sentença, implicará a expedição de ordem judicial à autoridade administrativa para que cumpra seu poder-dever de agir e formalize manifestação volitiva expressa, sob pena de desobediência a ordem judicial $^{182}$.

Celso Antônio Bandeira de Mello entende que, se o ato omitido se tratar de ato vinculado, o administrado pode pedir, diretamente, que o juiz supra a inércia da Administração. Com efeito, escreve o autor:

Nos casos em que a lei nada dispõe, as soluções seguem, mutatis mutandis, equivalente diapasão. Decorrido o prazo legal previsto para a manifestação administrativa, se houver prazo normativamente estabelecido, ou, não havendo, se já tiver decorrido tempo razoável (cuja dilação em seguida será mencionada), o administrado poderá, conforme a hipótese, demandar judicialmente:

a) que o juiz supra a ausência de manifestação administrativa e determine a concessão do que fora postulado, se o administrado tinha direito ao que pedira, isto é, se a Administração estava vinculada quanto ao conteúdo do ato e era obrigatório o deferimento da postulação;

b) que o juiz assine prazo para que a Administração se manifeste, sob a cominação de multa diária, se a Administração dispunha de discrição administrativa no caso, pois o administrado fazia jus a um pronunciamento motivado, mas tão-somente a isto ${ }^{183}$.

José dos Santos Carvalho Filho rebate:

Há juristas, no entanto, que sustentam que, se a Administração estava vinculada ao conteúdo do ato não praticado (ato vinculado), e

\footnotetext{
${ }^{182}$ CARVALHO FILHO, José dos Santos. Manual de Direito Administrativo. $18^{\mathrm{a}}$ ed. Rio de Janeiro: Lumen Iuris, 2007, p. 95.

${ }^{183}$ BANDEIRA DE MELLO, Celso Antônio. Curso de Direito Administrativo. 22 ${ }^{\mathrm{a}}$ ed. São Paulo: Malheiros, 2007, p. 398.
} 
tendo o interessado direito ao que postulara, poderia o juiz suprir a ausência de manifestação. Ousamos dissentir desse entendimento, porquanto não pode o órgão jurisdicional substituir a vontade do órgão administrativo; pode, isso sim, obrigá-lo a emiti-la, se a lei o impuser, arcando $\mathrm{o}$ administrador com as conseqüências de eventual descumprimento ${ }^{184}$.

\section{Esclarece o autor carioca:}

Por via de conseqüência, vale a pena anotar que a impugnação ao silêncio administrativo (omissões administrativas) não se confunde com a dirigida à invalidade de atos. Por isso é que são duas etapas a serem percorridas pelo interessado: na primeira, busca obter decisão que obrigue à manifestação do agente omisso (decisão mandamental); na segunda é que, sanada a omissão, o interessado postula a anulação do ato, se entender que está contaminado de vício de legalidade (decisão constitutiva) $)^{185}$.

De fato, parece que, sendo o ato omitido discricionário, não pode o juiz suprir a omissão e atender, diretamente, o interesse do particular. Pode, pelos meios de apoio de que dispõe, determinar à Administração que se manifeste, dentro em um prazo razoável.

Todavia, tendo o ato omitido natureza vinculada, não repugna a idéia de que o Judiciário possa suprir a omissão. É preciso ter presente, apenas, que o particular deve comprovar os requisitos que lhe conferem o direito à emanação de um ato positivo. Nem sempre o juiz dispõe dos meios técnicos para verificar se as exigências de lei foram atendidas - por exemplo, se um projeto está de acordo com o Código de Obras Municipal. Neste caso, em vez de designar peritos, o que demandaria um termo enorme para a conclusão do processo, melhor solução se afigura determinar ao administrador que se manifeste - favorável ou desfavoravelmente ao pedido do interessado.

Em suma: se o ato omitido for discricionário, o julgador não pode senão determinar à Administração que se manifeste; se o ato for vinculado, o juiz pode anotar prazo para o administrador praticar o ato ou pode suprir a omissão, desde que a aferição do preenchimento dos requisitos legais esteja a seu alcance.

${ }^{184}$ CARVALHO FILHO, José dos Santos. Manual de Direito Administrativo. $18^{\mathrm{a}}$ ed. Rio de Janeiro: Lumen Iuris, 2007, p. 96.

${ }^{185}$ CARVALHO FILHO, José dos Santos. Manual de Direito Administrativo. $18^{\mathrm{a}}$ ed. Rio de Janeiro: Lumen Iuris, 2007, p. 96. 


\subsection{O estabelecimento de astreintes contra o Poder Público}

Discussão interessante diretamente ligada à questão do controle jurisdicional do silêncio administrativo é a possibilidade de se estabelecerem astreintes contra o Poder Público, como forma de compeli-lo a tomar uma decisão. A discussão ganha especial relevo quando a decisão omitida tem (ou teria) caráter discricionário, ou ainda quando o ato omitido, conquanto vinculado, só pode ser praticado pelo administrador, em decorrência dos aspectos técnicos que envolve. Isso porque nesses casos, o Juiz não poderia, em princípio, suprir a omissão estatal.

A expressão astreinte vem do francês. Cuida-se do substantivo correspondente ao verbo astreindre, sinônimo de constraindre, que significa constranger, compelir. $\mathrm{O}$ objetivo das astreintes é, pois, compelir o devedor a adimplir a obrigação. Cuida-se, portanto, de meio de coação. Amílcar de Castro escreve:

Os meios executivos, conforme técnica de Chiovenda, podem ser de coação e sub-rogação. Denominam-se de coação os que tendem a conseguir o bem devido ao exeqüente com a devida participação do executado, influindo na vontade deste, a fim de que se resolva a prestar o que deve. Assim são as multas, a prisão e o seqüestro com função coercitiva.

E os meio de sub-rogação os que tendem a conseguir o bem devido, independentemente da participação e, portanto, da vontade do obrigado, tal como a penhora.

A multa por dia de atraso é simples meio de coação. Multa-se o executado dia a dia, não para puni-lo, como se criminoso fosse, mas simplesmente para forçá-lo indiretamente a fazer o que deve, ou a não fazer o que não deve. Numa palavra: o juiz é forçado a multar para conseguir um meio de desempenhar a sua função jurisdicional ${ }^{186}$.

Aqueles que se posicionam contrariamente à possibilidade de se estabelecerem astreintes contra a Fazenda Pública argumentam que os bens desta são públicos, de natureza indisponível. Sendo assim, o arbitramento de multa por atraso de cumprimento de sentença judicial equivaleria a dar supremacia a interesse privado em detrimento do público.

${ }^{186}$ CASTRO, Amílcar de. Comentários ao Código de Processo Civil. Vol. VIII. 2 ${ }^{\mathrm{a}}$ ed. São Paulo : RT, 1976, p. 186. 
Ademais, as astreintes não teriam, em se tratando de Fazenda Pública, o efeito cominatório pretendido pelo Código de Processo Civil. Isso porque o atraso no cumprimento de decisões judiciais, muitas vezes, se deveria a entraves burocráticos, estando fora do alcance do agente público afastá-los. Aliás, não raro a demora e a necessidade de cumprimento de várias etapas antes do cumprimento de uma decisão seria decorrente da necessária obediência ao princípio da legalidade - o que impede o agente administrativo de tomar uma decisão célere, mas sem amparo de lei, portaria, instrução etc.

Além disso, como ressaltou Alcides de Mendonça Lima, "as astreintes correspondem a uma coação de caráter econômico, no sentido de influírem no ânimo do devedor, psicologicamente, para que cumpra a prestação de que está se esquivando" 187. Ora, a Administração não tem ânimo, não tem vontade. A vontade do Estado é dada pela lei. Se uma decisão judicial não é cumprida, isso decorre, normalmente, da inação de um agente público. E impor a multa ao Erário não influi, necessariamente, no ânimo deste agente. Em última análise, o prejuízo não será seu, mas dos cofres públicos.

É neste sentido a posição de Vicente Greco Filho:

Entendemos, também, serem inviáveis a cominação e a imposição de multa contra pessoa jurídica de direito público. Os meios executivos contra a Fazenda Pública são outros. Contra esta a multa não tem nenhum efeito cominatório porque não é o administrador renitente que irá pagá-la, mas os cofres públicos, ou seja, o povo. Não tem efeito cominatório, não tem sentido sua utilização como meio executivo ${ }^{188}$.

Há quem defenda, contudo, serem cabíveis as astreintes mesmo quando o devedor da obrigação de fazer seja a Fazenda Pública. O principal argumento em favor desta possibilidade é o de que não existe, na lei, nada que exima a Fazenda da imposição da multa do artigo 461-A, $\S 1^{\circ}$, e do artigo 645 do do Código de Processo Civil. E os benefícios processuais da Fazenda são somente aqueles expressos em lei, não podendo ser presumidos, por se tratar de exceção ao princípio da isonomia entre as partes litigantes.

\footnotetext{
${ }^{187}$ LIMA, Alcides de Mendonça. Comentários ao Código de Processo Civil. Vol VI. Tomo II. $1^{\text {a }}$ ed. Rio de Janeiro: Forense, 1974, p.775.

${ }^{188}$ GRECO FILHO, Vicente. Direito Processual Civil Brasileiro. $3^{\mathrm{o}}$ vol. $12^{\mathrm{a}}$ ed. São Paulo: Saraiva, 1997, p.69.
} 
A jurisprudência nacional é maciçamente favorável a esta tese. Neste sentido, verbi gratia:

AGRAVO DE INSTRUMENTO - Fazenda Pública - Multa cominatória ("astreinte") - Ação ordinária contra ela movida, em fase de execução Citação para cumprir a obrigação de fazer - Prazo de 60 dias sob pena de aplicação de multa diária por dia de atraso - Admissibilidade - Recurso não provido. A multa cominatória ("astreinte"), prevista como sanção na lei de regência tem por objetivo obrigar o vencido a cumprir a obrigação, a lei não excluiu a Fazenda Pública dessa obrigação, pois segundo a sua dicção qualquer pessoa submete-se a essa imposição. Não se pode olvidar que os privilégios que se concedem a determinados entes, quando figurem no pólo ativo ou passivo da ação judicial, devem ter previsão legal expressa, pois tratamento processual desigual, ademais de ofender o princípio da isonomia, não se presume " (TJ/SP - Agravo de Instrumento n 209 502-5 - São Paulo - 3a Câmara de Direito Público - Relator Rui Stoco - 200301 - VU )

EXECUÇÃO DE OBRIGAÇÃO DE FAZER - Fazenda Pública - Multa cominatória - Cabimento - O artigo 644 do Código de Processo Civil não excepcionou o Estado de sua incidência - Prerrogativas funcionais processuais devem ser expressamente previstas, diante do princípio da igualdade das partes do processo - O valor da "astreinte", no entanto, deve guardar proporcionalidade com a finalidade da pena - Multa reduzida - Agravo parcialmente provido para esse fim (TJ/SP - Agravo de Instrumento n 156 854-5 - São Paulo - 7a Câmara de Direito Público Relator Guerrien Rezende -17 04 00- VU)

COMINATÓRIA - Execução de sentença proferida em ação ordinária movida por funcionário público em face da Fazenda do Estado Concessão do prazo de 30 dias para cumprimento da obrigação de fazer, sob pena de multa diária - Imposição possível (art 644, do CPC) Recurso desprovido (TJ/SPAgravo de Instrumento n 153 510-5 - São Paulo - 8a Câmara de Direito Público - Relator Paulo Travam -160200VU)

Mas o arbitramento de astreintes contra o Poder Público deve levar em consideração outros fatores. O primeiro deles é, justamente, a questão da necessária obediência ao princípio da legalidade. Diferentemente do particular, a Administração está obrigada a observar uma série de trâmites quando deseja praticar um ato administrativo como comprar um bem, por exemplo. Além disso, muitas vezes a conclusão de um ato depende da cooperação de vários servidores, que devem atuar nas diferentes etapas de sua formação - é o que se costuma designar de atos administrativos complexos ("quando para a sua prolação de exige mais de uma declaração de vontade unitária" "189) ou compostos 
(“que demandam uma vontade unitária mas dependem de verificação, ratificação ou ciência de outro órgão ou agente para operacionalizar-se ${ }^{190 " ») . ~}$

Sendo assim, o julgador deve ter em mente que a atividade administrativa nunca poderá ser tão célere quanto a de um particular. Não pode, então, fixar um prazo por demais exíguo para o cumprimento da obrigação. A jurisprudência tem reconhecido que, para a validade das astreintes fixadas contra a Fazenda Pública, o prazo anotado para cumprimento da decisão judicial deve ser razoável:

RECURSO - Agravo de Instrumento - Execução de sentença - Obrigação de fazer - Prazo razoável (60 dias) para cumprimento - Exigüidade não demonstrada - Multa cominatória, fixada nesta fase - Faculdade prevista na atual redação do artigo 644, do Código de Processo Civil - Decisão monocrática, incensurável - Recurso improvido (TJ/SP Agravo de Instrumento n ${ }^{\circ} 43$ 026-5 - São Paulo -5a Câmara de Direito Público Relator Wilham Marinho -14 0891 -VU 741/423/05)

O Superior Tribunal de Justiça tem interessante decisão sobre o tema. No caso julgado, reconheceu-se a mora administrativa. Não obstante, observou o Tribunal que o prazo legal era muito reduzido, consideradas as limitações materiais e humanas a que se submete a Administração. A solução foi estabelecer um novo prazo, mais dilatado, para que a Administração proferisse a decisão omitida, sob pena de multa diária. Confira-se:

Administrativo - Recurso Especial - Mandado de Segurança - Processo Administrativo - Demora em decidir - 1 - De acordo com o art. 49 da Lei $\mathrm{n}^{\text {o }}$ 9.784, de 29/1/1999, concluída a instrução de Processo Administrativo, a Administração tem o prazo de até 32 (trinta e dois) dias para decidir, salvo prorrogação por igual período expressamente motivada. 2 - Comprovada a omissão da autoridade administrativa em decidir no prazo acima definido, há de se confirmar Mandado de Segurança concedido para que, no caso, a Receita Federal analise e decida os pedidos de ressarcimento formulados pela recorrida no prazo de 120 (cento e vinte) dias. Multa devida pelo descumprimento. 3 Homenagem que a Administração Pública deve prestar aos Princípios da Legalidade, da Eficiência e do Respeito aos Direitos Subjetivos da Cidadania. 4 - Recurso Especial não provido (STJ - $1^{\mathrm{a}} \mathrm{T}$.; REsp $\mathrm{n}^{\mathrm{o}}$ 980.271-SC; Rel. Min. José Delgado; j. 18/12/2007; v.u.).

${ }^{190}$ ARAÚJO, Edmir Netto de. Curso de Direito Administrativo. $1^{\text {a }}$ ed. São Paulo: Saraiva, 2005, p. 442. 
Em seu voto, o Ministro José Delgado transcreveu parte do voto condutor do acórdão recorrido. Nele, o desembargador relator do Tribunal de Justiça de Santa Catarina pontificou:

É certo que não desconheço as dificuldades de recursos humanos e materiais que afligem todos os setores da Administração e a complexidade que o trabalho em questão apresenta, demandando cálculos contábeis com certa dificuldade, como já frisei, e o zelo a ser adotado pelo servidor, não só em razão dos montantes significativos envolvidos, mas por se tratar de recursos públicos.

Esses fatores inviabilizam a pretensão como posta, pois 30 (trinta) dias é prazo insuficiente ao mister da Receita.

Muito embora já haja ultrapassado o lapso legal previsto no art. 49 da Lei $n^{\circ}$ 9.784/1999, e considerando a alegação da impetrante da demora na apreciação dos pedidos à análise das pretensões deduzidas na esfera administrativa, de outro lado a Fazenda informa a quantidade de processos a serem analisados (4 mil - fls. 63), bem como as preferências pelos pedidos efetuados por deficientes físicos/mentais ou pessoas portadoras de moléstias graves.

Desse modo, fixo o lapso de 120 (cento e vinte) dias para conclusão do procedimento analítico dos pedidos de ressarcimento encetados por B. Ltda., nestes Autos.

Caso haja descumprimento da obrigação, fixo a pena de multa diária no valor de $\mathrm{R} \$ 1.000,00$ (mil reais), em virtude da grande demora na apreciação dos pedidos.

Além disso, deve-se ter presente que o valor estabelecido a título de astreintes é, sempre, provisório, podendo ser diminuído ou aumentado pelo juiz no momento da execução. A jurisprudência o confirma:

A multa pelo descumprimento de decisão judicial não pode ensejar o enriquecimento sem causa da parte a quem favorece, como no caso, devendo ser reduzida a patamares razoáveis (STJ - 4a T., REsp 793.491, rei. Min. César Rocha, j . 26.9.06, em Theotonio Negrão, Código de Processo Civil e legislação processual em vigor, 40 edição, 2008, p. $563)$.

A multa poderá, mesmo depois de transitada em julgado a sentença, ser modificada, para mais ou para menos, conforme seja insuficiente ou excessiva. $\mathrm{O}$ dispositivo indica que o valor da astreinte não faz coisa julgada material, pois pode ser revista mediante a verificação de insuficiência ou excessividade. $\mathrm{O}$ excesso a que chegou a multa aplicada justifica a redução (STJ - 3a T., REsp 705.914, rei. Min. Gomes de Barros, j . 15.12.05, em Theotonio, obra citada, mesma página)

Uma vez verificado que a multa não cumpriu com sua função coercitiva, ou que o recebimento da mesma poderá implicar no enriquecimento indevido da parte contrária, o juiz poderá reduzir o crédito resultante da incidência das astreintes. Aplicação dos arts. 644 e 46,1 § 6o, do CPC. A 
redução da multa não implica em ofensa à coisa julgada, posto que o crédito resultante das astreintes não integra a lide propriamente dita e, portanto, não faz parte das 'questões já decididas, relativas à mesma lide' (art. 471 do CPC) (RJTJRGS 255/286).

Portanto, ainda que cumprida a destempo a decisão, o juiz pode, a seu critério, verificando os elementos do processo, diminuir o valor das astreintes. Em se tratando de Fazenda Pública, parece que o juiz a pode isentar completamente do pagamento da multa, se entender que o cumprimento tardio foi plenamente justificável. É que, neste caso, não houve recalcitrância quanto ao cumprimento da ordem judicial, mas impossibilidade de fazê-lo tempestivamente.

Deve-se observar, outrossim, que muitos autores sustentam ser possível a cobrança das astreintes do agente público responsável pela mora. Leonardo José Carneiro da Cunha, por exemplo, afirma: "Para conferir efetividade ao comando judicial cabe, portanto, a fixação de multa, com esteio no $\S^{\circ}$ do art. 461 do CPC, a ser exigida do agente público responsável, além de se exigir da própria pessoa jurídica de direito público" ${ }^{\text {"191 }}$.

Parece mais razoável, porém, que o valor das astreintes possa ser exigido pelo Estado do funcionário, eventualmente, em ação de regresso. Isso porque na ação principal, isto é, na ação em cujo curso foram impostas as astreintes, o funcionário não é parte, mas o Estado. Acresça-se a isso o fato de que nem sempre a competência para a prática de um ato é perfeitamente identificável - até porque a formação deste pode depender de mais de um agente, como visto. Por fim, impor a multa ao funcionário que no entender do juiz seja o competente para a prática do ato parece ferir o princípio do contraditório. Se o Estado exigir seu ressarcimento do funcionário em ação própria, este poderá defender-se e até mesmo comprovar que não deu causa à mora.

${ }^{191}$ CUNHA, Leonardo José Carneiro da. A Fazenda Pública em Juízo. $3^{\text {a }}$ ed. São Paulo: Dialética, 2005, p. 124. 


\subsection{Responsabilização do Estado pelo silêncio administrativo}

Em linhas gerais, para que haja responsabilidade civil é preciso que haja dano e nexo causal. Na responsabilidade civil aquiliana, deve-se comprovar, ainda, culpa ou dolo. A responsabilização do Estado, porém, prescinde de culpa, a teor do artigo $37, \S 6^{\circ}$, da Constituição Federal.

Contudo, quando se trata de comportamento omissivo, a tendência da doutrina é exigir, também, a prova da culpa do Estado. Explica Celso Antonio Bandeira de Mello:

Quando o dano foi possível em decorrência de uma omissão do Estado (o serviço não funcionou, funcionou tardia ou ineficientemente) é de se aplicar a teoria da responsabilidade subjetiva. Com efeito, se o Estado não agiu, não pode, logicamente, ser ele o autor do dano. E, se não foi o autor, só cabe responsabilizá-lo caso esteja obrigado a impedir o dano. Isto é: só faz sentido responsabilizá-lo se descumpriu dever legal que lhe impunha obstar ao evento lesivo.

Deveras, caso o Poder Público não estivesse obrigado a impedir o acontecimento danoso, faltaria razão para impor-lhe o encargo de suportar patrimonialmente as consequiências da lesão. Logo, a responsabilidade estatal por ato omissivo é sempre responsabilidade por comportamento ilícito. E, sendo responsabilidade por ilícito, é necessariamente responsabilidade subjetiva, pois não há conduta ilícita do Estado (embora do particular possa haver) que não seja proveniente de negligência, imprudência ou imperícia (culpa) ou, então, deliberado propósito de violar a norma que o constituía em dada obrigação (dolo). Culpa e dolo são justamente as modalidades de responsabilidade subjetiva $^{192}$.

Pois bem. No caso do silêncio administrativo, pode ocorrer uma de três situações: a) a legislação prevê um prazo para a Administração manifestar-se, bem como a conseqüência de sua omissão; b) a legislação prevê um prazo para a manifestação da Administração, mas não estabelece conseqüência para o não-atendimento da regra; c) a lei não estabelece prazo para a Administração expedir pronunciamento.

\footnotetext{
192 BANDEIRA DE MELlO, Celso Antônio. Curso de Direito Administrativo. 22ª ed. São Paulo: Malheiros, 2007, PP. $976 / 977$.
} 
$\mathrm{Na}$ primeira hipótese, estatuindo a lei o prazo e a conseqüência do silêncio administrativo, responsabilizar a Administração não oferece maiores dificuldades. Isso porque, ao prever um determinado resultado, concessivo ou denegatório da pretensão do administrado, a lei presume a ocorrência de um ato administrativo (tácito). Ainda que se discuta a natureza do silêncio - se ato ou fato jurídico administrativo, conforme já se discorreu no segundo capítulo deste trabalho ${ }^{193}$ - seu controle se dá de forma idêntica à dos atos administrativos em geral. Assim, também, a responsabilização do Estado.

Vale dizer que nesta primeira hipótese, em que a lei prevê o resultado do silêncio, o que gerará, eventualmente, responsabilização do Estado não é a omissão estatal, mas o ato que se presumiu praticado. Neste caso, incumbirá ao administrado comprovar que sofreu um prejuízo (dano) decorrente do ato positivo ou negativo gerado pela inércia da Administração (nexo etiológico).

Deve-se ressaltar que, quando a lei estabelece a conseqüência decorrente da ausência de manifestação tempestiva da Administração, o silêncio não é um comportamento ilícito, mas uma verdadeira faculdade da Administração. Aliás, como se viu ao tratar dos ordenamentos estrangeiros, muitas vezes a técnica do silêncio administrativo é vista como uma forma de agilizar a prestação administrativa, tornando prescindível uma resposta motivada. Pode ocorrer, porém, de a resposta (tácita) da Administração não ser adequada ao ordenamento. Nesses casos, portanto, poder-se-ia cogitar uma eventual responsabilização do Estado.

Pensemos, por exemplo, na hipótese de licença para construir - um dos casos mais comuns de silêncio positivo da ordem jurídica brasileira ${ }^{194}$. Apresentando o interessado os documentos e declarações obrigatórios e transcorrido o prazo para a Administração, expressamente, conceder ou negar a licença de construção, considera-se deferido o pedido. Suponha-se que a licença tenha sido deferida, contrariamente a alguma exigência legal como, por exemplo, desrespeitando o zoneamento. Perante a Administração, evidentemente, o particular responde pelas declarações que, falsamente, houver prestado. $\mathrm{E}$ perante terceiros que se sintam prejudicados? Ao que parece, em princípio, poderiam ser responsabilizados tanto o particular como o Estado (ressalvando-se a este a possibilidade

${ }^{193}$ Confira-se o item "2.2 A natureza jurídica do silêncio", p. 62.

${ }^{194}$ Confira-se, ad exemplum, o Código Obras do Município de São Paulo, instituído pela Lei 11.228/92. 
de exercer direito de regresso contra o particular, se este tiver dado causa ao erro - como atestando em falso, por exemplo).

Quando a lei estabelece um prazo para a Administração manifestar-se e não uma conseqüência para o silêncio, parece evidente que a inércia administrativa é um comportamento (omissivo) ilícito. Incumbe ao administrado, então, comprovar o prejuízo que experimentou e o nexo causal entre este e a mora administrativa.

Se a lei estabelece, por exemplo, que a decisão deva ser proferida, em até trinta dias, e esta o é, após trinta e cinco, houve, em princípio, um retardamento ilícito. Mas só isso não basta. É preciso que o administrado demonstre qual prejuízo essa mora de cinco dias lhe causou.

A hipótese mais complicada é a última: a lei não prevê nem prazo para manifestação, nem conseqüência para a omissão estatal. Para responsabilizar o Estado, não bastaria ao particular comprovar o dano e o nexo causal. Impor-se-ia, mais, caracterizar a mora administrativa. Em casos extremos, a aplicação do princípio constitucional da duração razoável dos processos (art. 5, LXXVIII, CF) poderia deixar patente a mora da Administração (não é razoável, por exemplo, que um pedido fique durante dez anos parado, sem, absolutamente, nenhuma providência da Administração). Mas há casos limítrofes, que podem gerar dúvidas. Por exemplo: um pedido não foi deferido ou indeferido um ano depois de protocolizado. Neste ínterim, porém, os autos administrativos tramitaram por diversos órgãos para colheita de manifestações técnicas, foi o interessado intimado a complementar a documentação apresentada etc. Pode-se dizer que o procedimento extrapolou um tempo razoável?

Neste último caso, parece quase que imprescindível que o administrado dirija-se às instâncias judiciais. Então, como visto, em se tratando de ato administrativo discricionário, o Juiz anotará prazo para que a Administração se manifeste. Desatendido o prazo, está aberto o caminho para a responsabilização (devendo, ainda, o administrado fazer prova do dano e do nexo etiológico). 
Quanto ao tema da responsabilização do Estado pela demora administrativa, Miguel Seabra Fagundes elaborou parecer. Cuidava-se de hipótese em que a empresa Empreendimentos Odebrecht Ltda. buscava obter aprovação de um projeto de loteamento no Recife. Após diversos pareceres favoráveis dos órgãos administrativos, houve mudança de gestão, e a oposição começou a criticar o empreendimento, por haver Mata Atlântica na área a ser loteada. Ainda se tentou realizar termo de acordo, de modo a que a mata fosse preservada pelo loteamento, mas a Prefeitura do Recife, sob pressão política, fez com que o projeto não fosse, definitivamente, aprovado, postergando-se a decisão. Nesse ínterim, entrou em vigor a Lei 6.766/79, tendo-se determinado que a análise do projeto fosse refeita. Caracterizou-se, então, a posteriori, a inviabilidade do projeto.

Miguel Seabra Fagundes opinou:

1. O comportamento da Prefeitura Municipal, na apreciação de projetos de loteamento, de construção e de quaisquer outros, há de pautar-se em conformidade com a legislação vigorante enquanto submetidos eles ao seu exame e aprovação, isto é, vigorante na data do protocolamento e acaso sobrevinda no curso da tramitação normal do processo. Reter projeto sob o fundamento de que legislação futura poderá interferir com aspectos dele, é proceder, por omissão, contra a lei.

3. No Estado de Direito vige o princípio da legalidade, segundo o qual todas as atividades do poder púbico são submissas à Constituição e às leis. E essa submissão significa o dever de acatar o direito escrito, quer para não agir sem base nele, quer para agir sempre que lhe cumpra dar execução a quaisquer textos de lei. Assim sendo, o administrador nem pode obrigar a procedimento que a lei não impõe, nem pode negar direito que se acha nela enunciado. O não fazer o que deve ser feito por força de lei é tão violador do princípio de legalidade, quanto fazer aquilo que a lei proíbe $^{195}$.

E, sobre o dever de indenizar os prejuízos, porventura advindos da mora administrativa, pontificou o autor:

1. Quando a inércia da Administração acarreta prejuízo ponderável para o administrado, dá lugar a reparação. Essa é uma conseqüência geralmente admitida (Andrè de Laubadère, Traité Elementaire de Droit Administratif, versão francesa de Simone Aicardi, pp. 436-438; H.W.R. Wade, Diritto Amministrativo Inglese, Giuffrè, p. 83), inclusive na jurisprudência padrão do Conselho de Estado da França. Aliás, entre os casos que o elenco de julgados desse reputado tribunal oferece como

\footnotetext{
${ }^{195}$ FAGUNDES, MIGUEL SEABRA. Responsabilidade do Estado - Indenização por Retardada Decisão
} Administrativa. em Revista de Direito Público jan/jun. São Paulo: RT, 1981, pp.12/13. 
típicos de omissão da Administração Pública, com reparação conseqüiente, estão o de demora na liberação de projeto de alinhamento e de retardamento no deliberar o Conselho Municipal sobre a execução de plano de expansão, desmatamento e embelezamento na comuna (Pierre Montané de la Roque, L'inertie des Pouvoirs Publics, Dalloz, p. 324), assemelháveis ao caso configurado na consulta.

2. É que - tal já vimos a propósito do segundo quesito - o indivíduo tem, como direito primário, o direito à aplicação das leis reguladoras de situações nas quais se encontre, ou de relações que lhe digam respeito.

3. Nem mesmo o ser discricionária a competência do administrador, lhe exclui o dever de decidir, pontualmente, sobre as pretensões a ele submetidas. Porque a discrição conferida ao agente executivo não o converte, se diante de uma postulação, em senhor do calar ou do falar: "o exercício da competência não é um privilégio, senão um dever para o agente, que tem a obrigação funcional de ser vigilante, mesmo em caso de competência discricionária" (Duez et Debeyere, Traité de Droit Administratif, $1^{\text {a }}$ ed, p. 424). O objetivo da discrição, em se tratando de pretensões do administrado, é a variação do entendimento no confronto ente elas e o interesse público, e não armar o administrador do poder de trancar-se a qualquer manifestação de vontade. Se tal fora possível, a competência discricionária o converteria em senhor absoluto dos direitos subjetivos, acaso dependentes da sua decisão ${ }^{196}$.

E conclui:

(...) se pelo levantamento das datas se puder constatar ter havido lerdeza da Prefeitura, no despacho do pedido de loteamento, que levou a situar-se o seu exame sob a vigência de lei nova mais restritiva (Lei 6.766, de 19.12.1979), a Prefeitura responderá civilmente pelos prejuízos, que o agravamento das restrições lhes trouxe. Sim, porque a requerente não as sofreria se pontual o despacho ${ }^{197}$.

Incumbe ao administrado, pois, comprovar o prejuízo experimentado e, ainda, que este prejuízo foi causado pela mora da Administração, isto é, o dano e o nexo de causalidade.

\footnotetext{
${ }^{196}$ FAGUNDES, MIGUEL SEABRA. Responsabilidade do Estado - Indenização por Retardada Decisão Administrativa. em Revista de Direito Público jan/jun. São Paulo: RT, 1981, pp.13/14.

${ }^{197}$ FAGUNDES, MIGUEL SEABRA. Responsabilidade do Estado - Indenização por Retardada Decisão Administrativa. em Revista de Direito Público jan/jun. São Paulo: RT, 1981, p. 14.
} 


\subsection{A responsabilização do servidor pelo silêncio administrativo}

Outra questão que se apresenta diz respeito à responsabilização do servidor pela omissão do Estado -, mais particularmente, pelo silêncio administrativo.

De início, deve-se deixar assentado que, segundo parece, ao contrário do que acontece com o Estado, o servidor não pode ser responsabilizado por ato lícito. Sendo assim, nas hipóteses em que a legislação prevê um resultado para o silêncio administrativo, não pode ser o funcionário responsabilizado por não ter praticado o ato (salvo, é claro, nos casos de dolo e desvio de poder, caso se comprove que ele, podendo agir, deliberadamente, se omitiu, visando à obtenção do provimento previsto em lei em benefício próprio ou de terceiro).

Mas é certo que o servidor pode ser responsabilizado por omissão. A lei dos servidores públicos federais (Lei $\mathrm{n}^{\circ}$ 8.112/90) dispõe: “A responsabilidade civiladministrativa resulta de ato omissivo ou comissivo praticado no desempenho de cargo ou função" (art. 124).

É preciso ter presente, todavia, que a responsabilidade civil do servidor é aquiliana, devendo haver, ao lado da prova do dano e do nexo causal, comprovação de sua culpa ou dolo. Aliás, a Lei no 8.112/90 é expressa neste sentido:

Art. 122. A responsabilidade civil decorre de ato omissivo ou comissivo, doloso ou culposo, que resulte em prejuízo ao erário ou a terceiros.

$\S 1^{\circ} \mathrm{A}$ indenização de prejuízo dolosamente causado ao erário somente será liquidada na forma prevista no art. 46, na falta de outros bens que assegurem a execução do débito pela via judicial.

$\S 2^{\circ}$ Tratando-se de dano causado a terceiros, responderá o servidor perante a Fazenda Pública, em ação regressiva.

$\S 3^{\circ} \mathrm{A}$ obrigação de reparar o dano estende-se aos sucessores e contra eles será executada até o limite do valor da herança recebida.

Ora, se a Administração atribui a cinco servidores o encargo de analisarem cinco mil pedidos administrativos por mês, é certo que estes não podem ser considerados culpados por não conseguirem atendê-los tempestivamente. 
O funcionário também pode ser responsabilizado administrativamente. A lei 8.112/90 determina:

Art. 121. O servidor responde civil, penal e administrativamente pelo exercício irregular de suas atribuições.

Art. 126. A responsabilidade administrativa do servidor será afastada no caso de absolvição criminal que negue a existência do fato ou sua autoria.

Art. 127. São penalidades disciplinares:

I - advertência;

II - suspensão;

III - demissão;

IV - cassação de aposentadoria ou disponibilidade;

V - destituição de cargo em comissão;

VI - destituição de função comissionada.

Portanto, se restar caracterizada uma infração administrativa - por exemplo, se se apurar que o servidor descumpriu o dever de "atender com presteza à expedição de certidões requeridas para defesa de direito ou esclarecimento de situações de interesse pessoal" (art. 116, V, "b", Lei 8.112/90) ou se ignorou a proibição de "opor resistência injustificada ao andamento de documento e processo ou execução de serviço" (art. 117, IV, Lei 8.112/90) ou de "proceder de forma desidiosa" (art. 117, XV, Lei 8.112/90) - o funcionário poderá sofrer uma penalidade disciplinar.

O servidor pode, ainda, ser responsabilizado criminalmente. Com efeito, o Código Penal define o crime de prevaricação como "retardar ou deixar de praticar, indevidamente, ato de ofício, ou praticá-lo contra disposição expressa de lei, para satisfazer interesse ou sentimento pessoal" (art. 319, CP). O infrator se sujeita à pena de detenção, de três meses a um ano, e à imposição de multa.

O silêncio administrativo poderia vir a caracterizar, pois, o crime de prevaricação, em uma de suas formas omissivas. Como explica Guilherme de Souza Nucci,

indevidamente significa não permitido por lei, infringindo dever funcional. Assim, as duas primeiras condutas (retardar ou deixar de praticar) devem ser abrangidas por tal elemento. Exemplo da primeira conduta seria o funcionário que, por não se dar bem com o requerente de 
uma certidão, cuja expedição ficou ao seu encargo, deixa de expedi-la no prazo regular. Exemplo da segunda seria a conduta de delegado que, devendo instaurar inquérito policial, ao tomar ciência da prática de um crime de ação civil pública incondicionada, não o faz porque não queria trabalhar demais ${ }^{198}$.

Deve haver, portanto, o dever de agir. Julio Fabbrini Mirabete escreve que

é necessário que o agente infrinja disposição expressa de lei, não bastando a violação do princípio da moralidade. Não se pode falar em ato ilegítimo quando o funcionário tem certa disposição na escolha da conduta a tomar, uma certa discricionariedade que lhe é atribuída no exercício de suas funções ${ }^{199}$.

Ora, se deve haver violação de dever funcional, parece evidente que nos casos de silêncio positivo ou negativo, vale dizer, nos casos em que a lei atribui significação à inércia da Administração, não se pode dizer que a inação do funcionário seja ilícita. Todavia, como a consequiência do silêncio é idêntica à prática de um ato (concessivo ou denegatório), a conduta do agente poderia, conforme a situação, ser equiparada à prática de ato contrária a disposição de lei. É o que ocorreria, por exemplo, se o agente deixasse de manifestar-se com o fim de, deixando ocorrerem os efeitos do silêncio, alcançar fim diverso do previsto em lei. Cuidar-se-ia de uma hipótese de desvio de poder, passível de caracterizar crime.

Não se pode olvidar que para a caracterização do crime deve, ainda, haver dolo por parte do funcionário. Guilherme de Souza Nucci acresce: "Exige-se elemento subjetivo específico consistente na vontade de 'satisfazer interesse' ou 'sentimento pessoal'. Não existe a forma culposa" ${ }^{200}$. Neste sentido decidiu o Tribunal de Santa Catarina:

O simples retardamento de atos de ofício não configura, só por si, o crime de prevaricação. Sem o dolo específico, isto é, sem prova da intenção de satisfazer interesse ou sentimento pessoal, impossível condenar por tal espécie de delito. (RT 499/390).

Explicam Rui Stoco e Tatiana de O. Stoco: "O interesse pessoal pode ser de natureza material (patrimonial) ou moral. Este último pode ser identificado até mesmo no

\footnotetext{
${ }^{198}$ NUCCI, Guilherme de Souza. Código Penal Comentado. 6a ed. São Paulo: RT, 2006, p. 1.026.

${ }^{199}$ MIRABETE, Julio Fabbrini. Código Penal Interpretado. $5^{\text {a }}$ ed. São Paulo: Atlas, 2005, p. 2.369.

${ }^{200}$ NUCCI, Guilherme de Souza. Código Penal Comentado. 6 ${ }^{\mathrm{a}}$ ed. São Paulo: RT, 2006, p. 1.027.
} 
caso em que funcionário trai o seu dever por comodismo, ou para cair nas boas graças de alguém"201.

Julio Fabbrini Mirabete enfatiza:

A omissão de ato funcional de ofício pode configurar outros crimes previstos no Código Penal (arts. $317, \S 1^{\circ}, 318,320$ etc.) ou em leis especiais, como o de abuso de autoridade (art. $4^{\circ}, c, d$, $i$, da Lei $\mathrm{n}^{\circ} 4.898$ de 9-12-1965), os descritos no Estatuto da Criança e do Adolescente (art. $231,234,235)$ etc $^{202}$.

Em síntese, sendo omitida a manifestação estatal diante de um pedido do administrado, pode haver responsabilização civil, administrativa e criminal do funcionário, exigindo-se, nas duas primeiras hipóteses, que tenha havido ao menos culpa de sua parte, e, para a caracterização do crime, que tenha sido movido por dolo.

Finalmente, cumpre lembrar que "as sanções civis, penais e administrativas poderão cumular-se, sendo independentes entre si” (art. 125, Lei 8.112/90).

${ }^{201}$ FRANCO, Alberto Silva, e STOCO, Rui (coordenadores). Código Penal e sua Interpretação. $8^{\mathrm{a}}$ ed. São Paulo: RT, 2007, p. 1.483.

${ }^{202}$ MIRABETE, Julio Fabbrini. Código Penal Interpretado. $5^{\mathrm{a}}$ ed. São Paulo: Atlas, 2005, p. 2.378. 


\subsection{A possibilidade de se praticar ato expresso após a caracterização de um "ato tácito"}

Outra questão interessante diz respeito à possibilidade de a Administração praticar um ato, expresso, depois de haver sido caracterizado um provimento, positivo ou negativo, decorrente da inércia da Administração, por um tempo legalmente estabelecido.

Nos direitos alienígenas, a tendência parece ser a de admitir tal possibilidade, pois a previsão de um resultado decorrente da mora da Administração não pode subtrair desta o direito de decidir expressa e motivadamente.

No Direito brasileiro, a solução não parece diferente. E isso por duas razões: em primeiro lugar, porque em o nosso sistema jurídico, a Administração tem, em princípio, o dever de decidir motivadamente. Não faria sentido que uma lei a impedisse de fazê-lo, ainda que fora do tempo considerado adequado.

Ademais, milita em favor dessa possibilidade o princípio da autotutela.

A súmula $n^{\circ} 473$ do Supremo Tribunal Federal foi aprovada em 3 de dezembro de 1969, com a seguinte redação:

A administração pode anular seus próprios atos, quando eivados de vícios que os tornam ilegais, porque deles não se originam direitos; ou revogálos, por motivo de conveniência e oportunidade, respeitados os direitos adquiridos e ressalvada, em todos os casos, a apreciação judicial.

Como escreveu Oswaldo Aranha Bandeira de Mello,

não teria sentido que para restabelecer a ordem jurídica, por ela mesma ferida, fosse a Administração Pública bater às portas dos Tribunais, para pleitear que um outro poder pronunciasse a nulidade do ato administrativo, a fim de que visse corrigida a irregularidade dos próprios atos que praticou ${ }^{203}$.

${ }^{203}$ BANDEIRA DE MELLO, Oswaldo Aranha. Princípios Gerais de Direito Administrativo. vol. I. $1^{\mathrm{a}} \mathrm{ed}$. Rio de Janeiro: Forense, 1969, p. 592. 
A autotutela abrange o poder da Administração de anular ou revogar seus próprios atos. A distinção não é, meramente, terminológica ou acadêmica. Os efeitos de uma ou outra modalidade são bastante diversos.

A anulação atinge um ato eivado de vício que o torna ilegal. Daí alguns autores sustentarem que não há, in casu, um poder de anular o ato ilegal, mas sim um poderdever. Neste sentido, escreveu Maria Sylvia Zanella Di Pietro:

Normalmente se diz que a anulação é um ato vinculado, a anulação é um poder-dever da administração pública, porque se o ato é ilegal, ela não pode deixar de anular. Também normalmente se diz que a revogação é um ato discricionário, é um poder da administração, que ela vai utilizar ou não, segundo razões de oportunidade e conveniência ${ }^{204}$.

De fato, não podendo a Administração consentir com a permanência de um ato administrativo, nitidamente ilegal, - o que contrariaria o princípio constitucional da legalidade - deveria ela necessariamente anulá-lo.

Todavia, a anulação não é, obrigatoriamente, a única via que se abre para a Administração diante de uma ilegalidade. Em alguns casos, poderá haver a hipótese de convalidação. Há, aliás, quem sustente que, existindo possibilidade de convalidação, devese preferir esta à anulação, por amor à segurança jurídica.

Pode-se concluir, então, que, diante de um vício de ilegalidade, a Administração tem o poder-dever de expurgá-lo - seja pela anulação, seja pela convalidação. Esta, aliás, é a conclusão de Edmir Netto de Araújo:

Não há, propriamente, um dever de convalidar o ato anulável, mas o dever de recompor a legalidade ferida, o que se faz tanto fulminando o ato viciado quanto convalidando-o, e esta opção, como se viu, é discricionariamente voltada à melhor solução para o direito, com vistas ao cumprimento do fim específico de interesse público do ato em revisão, pois o fim específico do novo ato é o resguardo da ordem jurídica ${ }^{205}$.

\footnotetext{
${ }^{204}$ DI PIETRO, Maria Sylvia Zanella. Poder de Revisão dos Atos Pela Administração. in BDA - Boletim de Direito Administrativo - abril/96, p. 197.

${ }^{205}$ ARAÚJO, Edmir Netto de. Curso de Direito Administrativo. São Paulo: Saraiva, 2005, p. 479.
} 
É importante ressaltar, porém, que a lei que regula o processo administrativo no estado de São Paulo deu preferência à convalidação sobre a revogação. É o que estabelece a Lei 10.177/98:

\footnotetext{
Artigo 10 - A Administração anulará seus atos inválidos, de ofício ou por provocação de pessoa interessada, salvo quando:

I - ultrapassado o prazo de 10 (dez) anos contado de sua produção;

II - da irregularidade não resultar qualquer prejuízo;

III - forem passíveis de convalidação.
}

Portanto, a lei bandeirante limitou a atividade do administrador - não há discricionariedade; sendo possível a convalidação, deve esta ser adotada, em detrimento da anulação.

A revogação, por sua vez, atinge ato que se tornou inoportuno ou inconveniente ou seja, tem por fundamento o que se convencionou chamar de mérito administrativo. A distinção ora apontada parte do chamado critério objetivo, amplamente aceito pela doutrina e jurisprudência. Há outros, porém; resume-os Régis Fernandes de Oliveira:

Costumam os autores apontar três critérios para o estudo e classificação da extinção dos efeitos do ato administrativo: 1 - subjetivo: $\mathrm{O}$ anulamento consistiria na eliminação do ato por parte de autoridade diversa da que o emanou; ao invés, a revogação consistiria em sua eliminação pela própria autoridade que o colocou no mundo jurídico. Seria denominado anulamento, pois, a extinção via jurisdicional, e revogação a extinção via administrativa, pouco importando se por razões de mérito ou de ilegalidade; 2 - objetivo: Segundo tal critério a anulação consistiria na eliminação de um ato viciado de ilegitimidade sem indagação sobre o órgão que procede a retirada. Seria revogação a eliminação do ato por motivo de mérito; 3 - misto: Quando o retiro de um ato viciado por ilegitimidade, por parte de autoridade diversa, seria anulamento enquanto que o retiro que ocorre por parte da autoridade que o emana, seria revogação. A mesma denominação seria dada ao retiro por parte de uma outra autoridade por motivo de mérito. ${ }^{206}$

Pode-se dizer, em linhas gerais, que o fundamento do poder (ou poder-dever) de anulação é o princípio da legalidade, e que o princípio da supremacia do interesse público sobre o privado respalda o poder de revogar.

${ }^{206}$ OLIVEIRA, Régis Fernandes de. Ato Administrativo. São Paulo: RT, 1978, p. 86. 
Importante ressaltar, ainda, que a autotutela administrativa pode ser exercida $e x$ officio pela Administração Pública. Vale dizer que a Administração não precisa ser, necessariamente, provocada por um interessado para pronunciar-se sobre a ilegalidade de um ato, ou para revogá-lo se cessadas as condições de oportunidade e conveniência que o motivaram. Porém ela pode, evidentemente, agir mediante provocação - por intermédio, por exemplo, dos recursos administrativos. Apenas esta provocação não é uma condição necessária de sua atuação - tal qual acontece com a jurisdição, que é, por definição, inerte.

Ora, quando a lei atribui à inércia administrativa um determinado efeito, concessivo ou denegatório do pedido do administrado, presume praticado um ato administrativo ainda que a natureza deste seja discutível. Os efeitos, porém, serão idênticos aos que adviriam se praticado um ato.

Se a Administração pode revogar ou anular, ex officio, o ato que praticou, expressa e motivadamente, parece lógico que possa, também, revogar ou anular o ato que adveio de sua mora.

Portanto, não se pode impedir a Administração de praticar um ato, expresso, depois da ocorrência de um silêncio positivo ou negativo, pois isto equivaleria a negar-lhe o poder de autotutela. Os limites a esta revisão, porém, são os mesmos existentes em relação à revisão dos atos administrativos expressos.

Houve muita discussão na doutrina acerca do limite do poder de anular os atos administrativos, havendo quem defendesse ser esta faculdade ilimitada no tempo, podendo ser ou não exercida conforme as exigências do interesse público ${ }^{207}$. Outros autores sustentaram que o prazo durante o qual a Administração poderia proceder à anulação coincidiria com o prazo judicial. Ao menos na órbita federal, a controvérsia está superada a lei que regula o processo administrativo (Lei 9.784/99) dispõe expressamente, no caput do seu artigo 24, que "o direito da Administração de anular os atos administrativos de que decorram efeitos favoráveis para os destinatários decai em 5 (cinco) anos, contados da data em que foram praticados, salvo comprovada má-fé". No estado de São Paulo, conforme já

${ }^{207}$ OLIVEIRA, Régis Fernandes de. Ato Administrativo. São Paulo: RT, 1978, p. 125. 
se mencionou, a Lei 10.177/98 estabelece o prazo de dez anos para a Administração anular seus atos inválidos, a contar da respectiva produção (art. 10, I).

A possibilidade de revogação dos atos encontra, ainda, outros limites, costumandose dizer que, nesses casos, opera-se a coisa julgada administrativa. Edmir Netto de Araújo menciona como exemplos o ato administrativo que tenha gerado direito subjetivo ao beneficiário; o ato administrativo vinculado (pois, quanto a este, não há que se falar em conveniência e oportunidade); o ato de efeitos instantâneos (pois, tendo a revogação eficácia ex nunc, restaria inócua); a decisão favorável em procedimento disciplinar etc ${ }^{208}$.

Deve-se observar, por fim, que o exercício da autotutela, conquanto configure atividade lícita do Poder Público, pode gerar o dever de indenizar. É o que ensina Lúcia Valle Figueiredo:

Estaríamos diante, destarte, da responsabilidade administrativa por ato lícito, em franco atendimento, pois, ao postulado constitucional contido no art. $37, \S 6^{\circ}$, do Diploma Básico, que não perquire - para esse efeito - da licitude da conduta administrativa ${ }^{209}$.

Rui Stoco anota:

dúvida não resta que se a revogação do ato administrativo alcançar situações e direitos subjetivos consolidados, com ofensa ao direito adquirido, e desse desfazimento surgir efetivo prejuízo, impõe-se ao Poder Público compô-lo, nascendo daí sua responsabilidade pelo dano verificado.

\section{(...)}

Resta indagar se a anulação do ato administrativo gera direito à indenização pelo particular. (...) Em um primeiro momento poder-se-ia sustentar que, se o ato nulo o é desde o nascedouro e que, por isso, não gera efeitos válidos, nem direitos ou obrigações e, portanto, sua anulação não gera direito à indenização. Contudo, não é bem é assim. (...) nas hipóteses de anulação do ato cabe ressalvar o direito dos terceiros de boafé, alcançados pelos efeitos incidentes do ato anulado, uma vez que estão amparados pela presunção de legitimidade que acompanha toda atividade da Administração Pública ${ }^{210}$.

\footnotetext{
${ }^{208}$ ARAÚJO, Edmir Netto de. Curso de Direito Administrativo. São Paulo: Saraiva, 2005, p. 471.

${ }^{209}$ FIGUEIREDO, Lúcia Valle. Curso de Direito Administrativo. 2a ed. São Paulo: Malheiros, 1995, p. 169.

${ }^{210}$ STOCO, Rui. Tratado de Responsabilidade Civil. 5a ed. São Paulo: RT, 2001, p. 775.
} 
Em suma, havendo direitos individuais afetados pelo exercício da autotutela, a Administração é obrigada a indenizá-los, ressalvada a hipótese má-fé. O Superior Tribunal de Justiça negou o direito à indenização de benfeitorias realizadas por pessoa em área da marinha, por inexistir boa-fé e por não ser justa a posse ${ }^{211}$. De outro lado, entendeu haver direito à indenização decorrente de uma anulação, em um caso em que

o Estado do Paraná alienou a particulares, indevidamente, terras devolutas da União. No momento seguinte buscou a anulação de seu próprio ato administrativo, mas não deixou, assim, de causar prejuízo à parte que, situada na última posição da cadeia dominial, foi desapossada do imóvel e teve o título de propriedade desconstituído (STJ - $1^{\mathrm{a}}$ Turma; Rel. Min José Delgado; REsp 175287/PR; j. em 21.02.2006; DJ 13.03.2006, p. 185).

Impõe-se, portanto, na questão da autotutela administrativa, conjugar os princípios da supremacia do interesse público sobre o particular e da legalidade como outros princípios constitucionais, além das garantias individuais dos cidadãos, como o respeito ao contraditório e a salvaguarda dos direitos adquiridos. É preciso, também, tutelar a boa-fé dos administrados, especialmente, em virtude da presunção de legitimidade que envolve os atos administrativos.

O raciocínio se transporta, integralmente, aos "atos" decorrentes do silêncio administrativo. A Administração não está impedida de os revogar ou anular, mas pode ser compelida a indenizar o particular, se sua conduta lhe causar prejuízo.

${ }^{211}$ STJ - 1 ${ }^{\text {a }}$ Turma; Rel. Min José Delgado; REsp 635980/PR; j. em 03.08.2004; DJ 27.09.2004, p. 271. 


\section{CONCLUSÕES}

A primeira conclusão a que chegamos, ao fim deste estudo, parece evidente: falta na legislação pátria um tratamento do silêncio administrativo. Não há regras gerais sobre o tema, como ocorre, por exemplo, em Portugal. O que há são regras esparsas, apenas. Quando não existe um tratamento legislativo específico, a questão da comprovação do interesse de agir se complica. Qual é o tempo razoável que o administrado deve esperar antes de propor uma ação? A solução pode variar, conforme a complexidade do pleito apresentado à Administração. Ademais, sendo a noção de razoabilidade verdadeiro conceito jurídico indeterminado, não há garantia de tratamento idêntico para os administrados, faltando-lhes segurança jurídica. Conforme o entendimento de cada juiz, o administrado conseguirá ou não obter um provimento de mérito.

A Constituição de 1988 tem origem democrática e entre seus objetivos, favoreceu o acesso à justiça, o controle da Administração etc. Sendo assim, o constituinte andou bem ao retirar da Constituição a possibilidade de se exigir o esgotamento das instâncias administrativas como condição para o ajuizamento de uma ação perante o Poder Judiciário, como ocorria nas Constituições de 1967 e 1969. A exigência poderia, mesmo, representar um entrave para que o administrado conseguisse levar seu pleito ao Judiciário. Todavia, ao deixar de repetir o prazo máximo para que a Administração decida sobre o pedido do interessado, o constituinte criou outro problema para o administrado - o da comprovação do interesse de agir quando houver silêncio administrativo, ou da comprovação da omissão administrativa quando da interposição de Mandado de Segurança ou Habeas Data.

Isso pode obrigar o administrado a ajuizar uma primeira ação, unicamente, com o fim de caracterizar a mora administrativa, de tornar o silêncio juridicamente relevante, para então ingressar com outra, na qual busque a satisfação de seu direito, a responsabilização do Estado etc. Exigir, porém, que o administrado mova uma ação apenas para caracterizar a mora administrativa parece ir pela contramão das modernas legislações (como a lei da arbitragem, por exemplo - Lei $n^{\circ} 9.307 / 96$ ), que pretendem diminuir a sobrecarga judicial. 
É preciso, portanto, que o assunto receba maior atenção dos legisladores. Mas é necessário, também, diminuir o preconceito em relação ao silêncio administrativo. Como se demonstrou, em muitos ordenamentos estrangeiros, ele tem sido visto não apenas como um instrumento em favor do administrado - que, depois do transcurso de um determinado lapso temporal, tem seu interesse satisfeito ou pode acessar o Poder Judiciário, como se tivesse havido a prática de um ato - mas também em favor da Administração, que tem sua atividade agilizada.

Em síntese, podem-se enumerar as seguintes conclusões:

1) o tema do silêncio administrativo carece, na nossa ordem jurídica, de tratamento legislativo específico;

2) nas hipóteses em que a lei dispuser sobre o prazo para a manifestação da Administração e a conseqüência do seu silêncio, o ato de deferimento ou indeferimento tácito poderá ser controlado pelo Poder Judiciário da mesma forma que seria se se tratasse de ato administrativo expresso;

3) a exigência da comprovação do silêncio da Administração como expressão do interesse de agir não ofende o princípio do acesso à justiça;

4) quando o ato omitido for vinculado, o administrado pode requerer ao Judiciário que reconheça seu direito, desde que este disponha dos meios para aferir se as exigências legais foram adimplidas;

5) se o ato omitido for discricionário, ou se se cuidar de ato vinculado, cuja emanação dependa da análise de elementos técnicos, o administrado deverá pleitear ao Judiciário que determine que a Administração se manifeste;

6) quando o Juiz impuser à Administração prazo para manifestar-se, deverá atentar ao princípio da razoabilidade, devendo, ainda, observar a complexidade do caso; 
7) o Juiz poderá estabelecer astreintes pelo descumprimento do prazo anotado; todavia, a multa não deve ser exagerada e, ainda, deve ser dispensada quando a autoridade justificar, satisfatoriamente, o atraso no cumprimento;

8) se tiver de arcar com as astreintes, a Administração pode exigi-las, na via regressiva, do funcionário que deu causa à mora, desde que tenha este agido com culpa ou dolo;

9) o Estado pode ser responsabilizado por sua inércia, desde que o administrado comprove que o Estado descumpriu um dever de agir, havendo entre esta omissão e um prejuízo por ele sofrido, nexo de causalidade;

10) o funcionário também pode ser responsabilizado civilmente, tanto pelo Estado, na via regressiva, como pelo administrado, diretamente; todavia, é imprescindível a prova da sua culpa;

11) o funcionário ainda pode ser responsabilizado administrativamente, se houver agido ao menos com culpa, e criminalmente, se tiver atuado com dolo, devendo haver prova do elemento subjetivo "para satisfazer interesse ou sentimento pessoal" (art. 319 do CP);

12) a Administração pode praticar um ato expresso contrário ao que implicitamente se presumiu praticado, mas pode ser compelida a indenizar o particular pelo prejuízo que lhe causar. 


\section{RESUMO}

Tendo em vista que o Estado vela por interesses que dizem respeito à sociedade de uma maneira geral - o interesse público, nas modalidades primário ou secundário - devese dotar a Administração de instrumentos para bem exercer seu mister. Daí uma série de princípios, como o da supremacia do interesse público sobre o privado, o da presunção de legalidade e veracidade dos atos administrativos, o da auto-executoridade dos atos administrativos, entre outros.

Todavia, muito freqüentemente, o cidadão não consegue, pleiteando perante a Administração, ter seu interesse satisfeito - seja o interesse a uma reparação civil, à obtenção de documentos, à concessão de uma licença ou mesmo ao pronunciamento sobre pedido por ele formulado. É imprescindível, pois, garantir-lhe o acesso ao Poder Judiciário.

Não se pode olvidar, contudo, que o Poder Judiciário, o Poder Executivo, assim como o Poder Legislativo, são poderes estatais que não se sobrepõem hierarquicamente, mas se limitam uns aos outros. É importante estudar, então, quais os limites dessa recíproca contenção - mais particularmente, neste trabalho, os limites ao controle jurisdicional dos atos administrativos.

Ocorre, porém, que não apenas a ação administrativa pode gerar prejuízo para o particular, mas também sua inércia. A omissão estatal é amplo campo de estudo, que envolve as políticas públicas, a prestação de serviços etc. Esta dissertação versa sobre uma forma particular de omissão estatal: o silêncio da Administração. O silêncio é a inércia da Administração diante de um pedido do particular. Ele fere, portanto, o direito do cidadão a obter uma manifestação do administrador.

É preciso, pois, estudar a natureza e as características do silêncio administrativo para que se possa concluir como pode o juiz atuar diante de uma demanda que envolva esse tipo de inércia. 


\section{RESUMÉ}

Étant donné que l'État veille par des intérêts concernant la société considérée globalement - l'intérêt public, dans les modalités primaire ou secondaire - il est nécessaire de douer l'Administration d'outils capables de bien exécuter son travail, dont une série de principes, comme celui de la suprématie de l'intérêt public sur le privé, celui de la présomption de légalité et véracité des actes administratifs, celui de l'auto-exécutorieté des actes administratifs, parmi d'autres.

Pourtant, très souvent le citoyen ne réussit pas, ayant demandé à l'Administration, à avoir son intérêt satisfait - soit l'intérêt à une réparation civile, à l'obtention de documents, à la concession d'un congé ou même à l'avis à propos d' une demande formulée par lui. C'est indispensable, ainsi, de lui assurer l'accès au Pouvoir Judiciaire.

On ne peut pas oublier, toutefois, que le Pouvoir Judiciaire et le Povoir Exécutif, ainsi comme le Pouvoir Legislatif, sont des pouvoirs de l'État qui ne se superposent pas, mais si restreignent les uns aux autres. C'est important, donc, d' étudier les bornes de cette contrainte mutuelle - plus particulièrement, dans ce mémoire, les bornes au contrôle juridictionnel des actes administratifs.

Il s'ensuit, cependant, que non seulement l'action administrative peut léser le particulier, mais aussi son inertie le peut. L'omission de l'État est un vaste champ d'étude, qui inclut les politiques publiques, la prestation de services etc. Cette dissertation discourt sur une forme particulière d'omission de l'État: le silence de l'Administration. Le silence est l'inertie de l'Administration face à une demande du privé. Il blesse, par conséquent, le droit du citoyen d' obtenir une manifestation de l'administrateur.

Il est nécessaire, donc, d' étudier la nature et les caractéristiques du silence administratif pour qu'on puisse conclure comment le juge peut agir vis-à-vis d' une demande correspondant à ce type d'inertie. 


\section{BIBLIOGRAFIA}

AMARAL, Antonio Carlos Cintra do. Extinção do Ato Administrativo. São Paulo: RT, 1978.

ARAÚJO, Edmir Netto de. Curso de Direito Administrativo. $1^{\text {a }}$ ed. São Paulo: Saraiva, 2005.

Do Negócio Jurídico Administrativo. $1^{\mathrm{a}}$ ed. São Paulo: RT, 1992.

BANDEIRA DE MELlO, Celso Antônio. Curso de Direito Administrativo. $11^{\mathrm{a}}$ e $22^{\mathrm{a}}$ ed. São Paulo: Malheiros, 1999 e 2007.

Discricionariedade e Controle Jurisdicional. 2a ed. São Paulo: Malheiros, 2003

BANDEIRA DE MELlO, Oswaldo Aranha. Princípios Gerais de Direito Administrativo. vol. I. $1^{\text {a }}$ ed. Rio de Janeiro: Forense, 1969.

BAPTISTA DA SILVA, Ovídio. Curso de Processo Civil. Vol. 1. $4^{\mathrm{a}}$ ed. São Paulo: RT, 1998.

BARBI, Celso Agrícola. Comentários ao Código de Processo Civil. Vol. I. Tomo I. $1^{\text {a }}$ ed. Rio de Janeiro: Forense, 1975

BASTOS, Celso Ribeiro. Curso de Direito Constitucional. $18^{\mathrm{a}}$ ed. São Paulo: Saraiva, 1997.

BIELSA, Rafael. Principios de Derecho Administrativo. $3^{\mathrm{a}}$ ed. Buenos Aires: Universidad Nacional Del Litoral - Santa Fe, 1942. 
BONAVIDES, Paulo. Curso de Direito Constitucional. 23 $3^{\mathrm{a}}$ ed. São Paulo: Malheiros, 2008 .

CAETANO, Marcello. Manual de Direito Administrativo. Vol. I. 10 ${ }^{\mathrm{a}}$ ed. Coimbra: Almedina, 2005.

CARVALHO FILHO, José dos Santos. Manual de Direito Administrativo. $18^{\mathrm{a}}$ ed. Rio de Janeiro: Lumen Iuris, 2007.

CASETTA, Elio. Compendio di Diritto Amministrativo. $6^{\mathrm{a}}$ ed. Milano: Giuffrè Editore, 2006.

CASTRO, Amílcar de. Comentários ao Código de Processo Civil. Vol. VIII. $2^{\mathrm{a}}$ ed. São Paulo : RT, 1976.

CHAPUS, René. Droit administratif général. Tome 1. 15ª ed. Paris: Montchrestien, 2001.

CHAUI, Marilena. Introdução à História da Filosofia. Vol. I. $2^{\mathrm{a}}$ ed. São Paulo: Companhia das Letras, 2002.

CINTRA, Antonio Carlos de Araújo. Controle dos Atos Administrativos quanto aos Motivos e à Motivação, in Motivo e Motivação do Ato Administrativo. São Paulo: RT, 1979.

CRETELlA JÚNIOR, José. Controle Jurisdicional do Ato Administrativo. $1^{\text {a }}$ ed. Rio de Janeiro: Forense, 1984.

Direito Administrativo. São Paulo: RT, 1962.

José. Dos Atos Administrativos Especiais. 2a ed. Rio de Janeiro: Forense, 1998. 
DALlARI, Dalmo de Abreu. Elementos de Teoria Geral do Estado. 19ª ed. São Paulo: Saraiva, 1995.

DANTAS, San Tiago. Programa de Direito Civil. Parte Geral. $3^{\text {a }}$ tiragem. Rio de Janeiro: Editora Rio, 1979

DE CICCO, Cláudio. História do Pensamento Jurídico e da Filosofia do Direito. $3^{\mathrm{a}}$ ed. São Paulo: Saraiva, 2006.

DI BENEDETTO, Ugo. Diritto Amministrativo. 3aII ed. Santarcangelo di Romagna: Maggioli, 2007.

DI PIETRO, Maria Sylvia Zanella. Direito Administrativo. 10ª ed. São Paulo: Atlas, 1998. Discricionariedade Administrativa na Constituição de 1988. São Paulo: Atlas, 1991. Discricionariedade Administrativa e Controle Judicial da Administração. In Processo Civil e Interesse Público. SALLES, Carlos Alberto de (organizador). São Paulo: RT, 2003, pp. 181/190.

Poder de Revisão dos Atos Pela Administração. BDA - Boletim de Direito Administrativo - abril/96.

FAGUNDES, Miguel Seabra. O Controle dos Atos Administrativos. $5^{\mathrm{a}}$ ed. Rio de Janeiro: Forense, 1979.

Responsabilidade do Estado - Indenização por Retardada Decisão Administrativa. em Revista de Direito Público jan/jun. São Paulo: RT, 1981.

FIGUEIREDO, Lúcia Valle. Curso de Direito Administrativo. $2^{\mathrm{a}}$ ed. São Paulo: Malheiros, 1995. 
FOILLARD, Philippe. Droit administratif. 12ª ed. Orléans: Paradigme, 2007.

FRANCO, Alberto Silva, e STOCO, Rui (coordenadores). Código Penal e sua Interpretação. $8^{\mathrm{a}}$ ed. São Paulo: RT, 2007.

FRANCO, Italo. Manuale Del nuovo diritto amministrativo. $1^{\mathrm{a}}$ ed. Vicenza: IPSOA, 2007.

FREIRE JÚNIOR, Américo Bedê. O Controle Judicial de Políticas Públicas. São Paulo: RT, 2005.

FREITAS, Juarez. O Controle dos Atos Administrativo e os princípios fundamentais. $3^{\mathrm{a}} \mathrm{ed}$. São Paulo: Malheiros, 2004.

GARCIA, Emerson (coordenador). Discricionariedade Administrativa. Rio de JaneIro: Lumen Juris, 2005.

GRECO FILHO, Vicente. Direito Processual Civil Brasileiro. $3^{\circ}$ vol. $12^{\mathrm{a}}$ ed. São Paulo: Saraiva, 1997.

HORBACH, Carlos Bastide. Teoria das Nulidades dos Ato Administrativo. $1^{\text {a }}$ ed. São Paulo: RT, 2007.

JUAN LIMA, Fernando E. el silencio Administrativo: Problemas Actuales. Revista Eletrônica de Direito do Estado - ReDE n07/2006, Instituto de Direito Público da Bahia, Salvador. Disponível na Internet: http://www.direitodoestado.com.br . Acesso em 15 de outubro de 2007.

JUSTEN FILHO, Marçal. Curso de Direito Administrativo. $1^{\mathrm{a}}$ ed. São Paulo: Saraiva, 2005.

LEBRETON, Gilles. Droit Administratif Général. 4ª ed. Paris: Dalloz, 2007. 
LENZA, Pedro. Direito Constitucional Esquematizado. $7^{\text {a }}$ ed., São Paulo: Método, 2004.

LIEBMAN, Enrico Tulio. Manuale di Diritto Processuale Civile. I. $3^{\mathrm{a}}$ ed. Milano: Giuffrè Editore, 1973.

LIMA, Alcides de Mendonça. Comentários ao Código de Processo Civil. Vol VI. Tomo II. $1^{\mathrm{a}}$ ed. Rio de Janeiro: Forense, 1974.

LINARES, Juan Francisco Linares. Fundamentos de Derecho Administrativo. Buenos Aires: Astrea, 1975.

LIMA, Ruy Cirne. Princípios de Direito Administrativo. $7^{\mathrm{a}}$ ed., atualizada por Paulo Alberto Pasqualini, São Paulo: Malheiros, 2007.

LOPES, Miguel Maria de Serpa. O Silêncio como Manifestação da Vontade. Rio de Janeiro: A. Coelho Branco Filho, 1935.

MARQUES, Floriano de Azevedo. Discricionariedade Administrativa e Controle Judicial da Administração. In Processo Civil e Interesse Público. SALLES, Carlos Alberto de (organizador). São Paulo: RT, 2003, pp. 191/198.

MAURER, Hartmut. HECK, Luís Afonso (trad.). Direito Administrativo Geral.1 ${ }^{\text {a }}$ ed. Brasileira. Barueri: Manole, 2006.

MEDAUAR, Odete. Direito Administrativo Moderno. $8^{\mathrm{a}}$ ed. São Paulo: RT, 2004.

MEIRELLES, Hely Lopes. Direito Administrativo Brasileiro. $26^{\mathrm{a}}$ ed., atualizada por Eurico Andrade Azevedo, Délcio Balestero Aleixo e José Emmanuel Burle Filho. São Paulo: Malheiros, 2001. Mandado de Segurança, Ação Popular, Ação Civil Pública, Mandado de Injunção, 'Habeas Data'”. 21 a ed., atualizada por Arnoldo Wald, São Paulo: Malheiros, 1999. 
MIRABETE, Julio Fabbrini. Código Penal Interpretado. 5ª ed. São Paulo: Atlas, 2005.

MIRANDA, Pontes de. Comentários ao Código de Processo Civil. Tomo I. $2^{\mathrm{a}}$ ed. Rio de Janeiro: Forense, 1979.

MORAES, Alexandre de. Direito Constitucional. $8^{\text {a }}$ ed. São Paulo: Atlas, 2000.

NEGRÃO, Theotonio, e GOUVÊA, José Roberto F. Código de Processo Civil e legislação processual em vigor. $38^{\text {a }}$ ed. São Paulo: Saraiva, 2006.

NERY JUNIOR, Nelson, e NERY, Rosa Maria Andrade. Código de Processo Civil Comentado. $2^{a}$ ed. São Paulo: RT, 1996.

NUCCI, Guilherme de Souza. Código Penal Comentado. 6ª ed. São Paulo: RT, 2006.

OLIVEIRA, Mario Esteves de, GONÇALVES, Pedro Costa e AMORIM, J. Pacheco. Código do Procedimento Administrativo Comentado. $2^{\text {a }}$ ed. Coimbra: Almedina, 2006.

OLIVEIRA, Régis Fernandes de. Ato Administrativo. São Paulo: RT, 1978.

OSÓRIO, Fábio Medina,e SOUTO, Marcos Juruena Villela (coordenadores). Direito Administrativo - Estudos em Homenagem a Diogo Figueiredo Moreira Neto. Rio de Janeiro: Lumen Juris, 2006.

PARADA, Ramón. Derecho Administrativo. I Parte general. 9a ed. Madrid: Marcial Pons, 1997.

PEREIRA JUNIOR, Jessé Torres. Controle Judicial da Administração Pública. Da legalidade estrita à lógica do razoável. $2^{\mathrm{a}}$ ed. Belo Horizonte: Fórum, 2006.

PIERCE JR., Richard Jr. Administrative Law. vol. III. $4^{\mathrm{a}}$ ed. New York: Aspen Publishers, 2002. 
QUEIRÓ, Afonso Rodrigues. A Teoria do “Desvio de Poder" em Direito Administrativo. RDA 6/41-78. Rio de Janeiro.

RIVERO, Jean. Ehrdaedt Soares, Rogério (trad.). Direito Administrativo. Coimbra: Almedina, 1981.

. Cretella Junior, José (trad.). Curso de Direito Administrativo Comparado. $2^{\mathrm{a}}$ ed. São Paulo: RT, 2004.

RODRIGUES, Sílvio. Direito Civil - Parte Geral. Vol. 1. 34 a ed. São Paulo: Saraiva, 2007.

SALEILLES, Raymond. De la Déclaration de Volonté. Contribution a L'Étude de L'Acte Juridique dans Le Code Civil Allemand. Paris : Librairie Costillon, 1901.

SICCA, Gerson dos Santos. Conceitos Indeterminados no Direito Administrativo e Discricionariedade: Limites da Vinculação do Administrador no Estado Democrático de Direito.in Revista da AGU, Ano 3, nº5. Brasília/DF: dezembro de 2004.

SILVA, José Afonso da. Curso de Direito Constitucional Positivo. 23 ${ }^{\text {a }}$ ed. São Paulo: Malheiros, 2004.

SILVA, Ovídio A. Baptista da. Curso de Processo Civil. Vol 1. $4^{\mathrm{a}}$ ed. São Paulo: RT, 1996.

STOCO,Rui. Tratado de Responsabilidade Civil. 5a ed. São Paulo: RT, 2001.

TACITO, Caio. O Desvio de poder no controle dos atos administrativos, legislativos e jurisdicionais. RDA 188/1. Rio de Janeiro. abr/jun. 1992.

TEMER, Michel. Elementos de Direito Constitucional. 18a ed. São Paulo: Malheiros, 2002. 
VITTA, Heraldo Garcia. O Silêncio no Direito Administrativo.RDA 218/113. Rio de Janeiro. out/dez/99.

WAMBIER, Luiz Rodrigues (coord.). Curso Avançado de Processo Civil. Vol. 1. $9^{\mathrm{a}}$ ed. São Paulo: RT, 2007.

WEFFORT, Francisco C. (organizador). Os Clássicos da Política. 6a ed. São Paulo: Ática, 1995.

ZANCANER, Weida. Da Convalidação e da Invalidação dos Atos Administrativos. $2^{\mathrm{a}}$ ed. São Paulo: Malheiros, 1993.

ZANOBINI, Guido. Curso de Derecho Administrativo. Vol. I. Buenos Aires: Ediciones Arayú, 1954. 